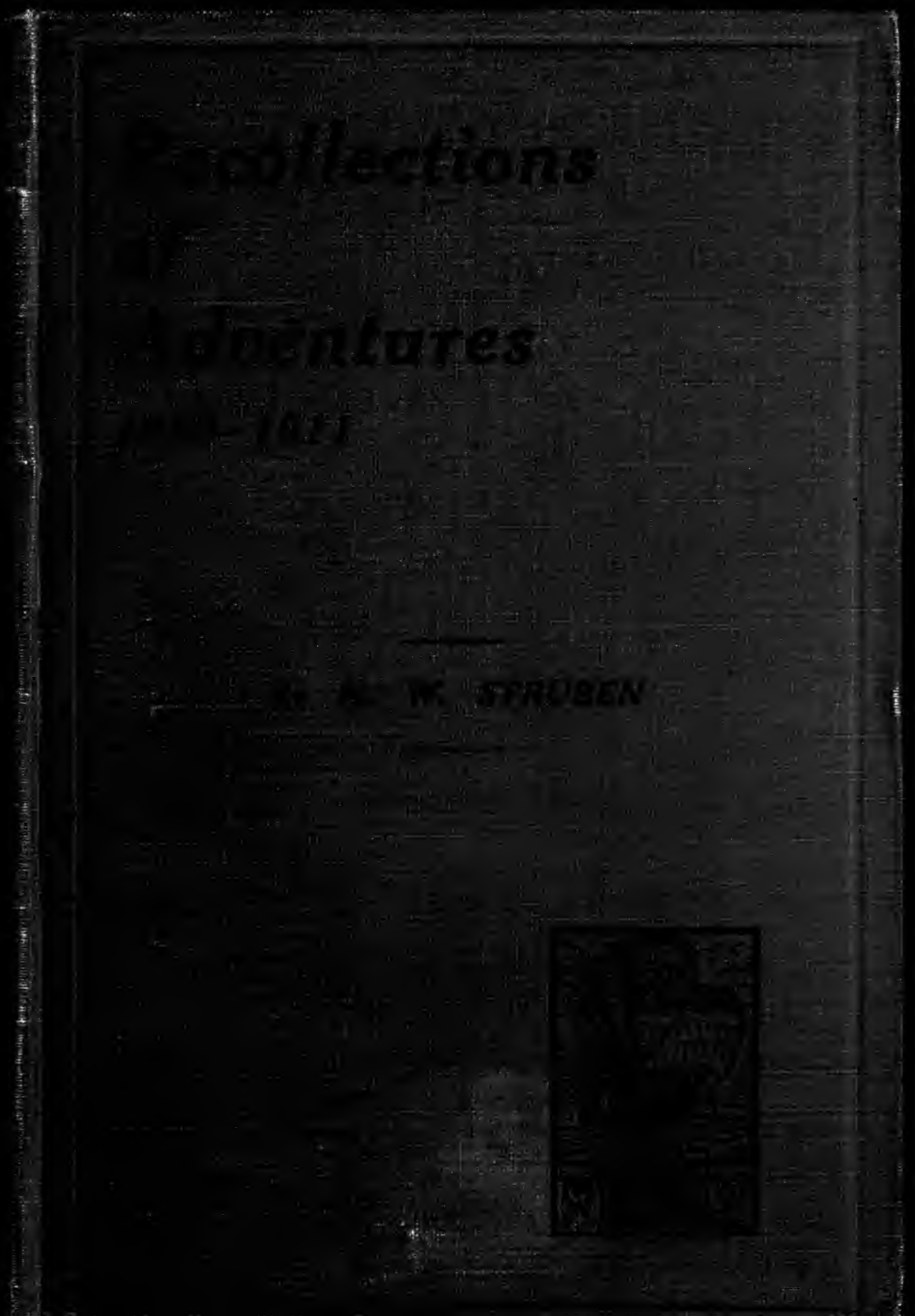




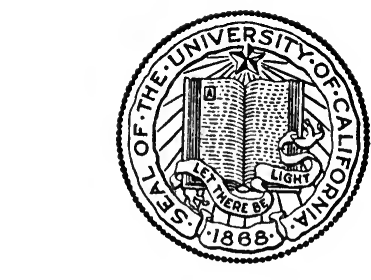

\section{THE LIBRARY} OF

\section{THE UNIVERSITY OF CALIFORNIA}

PRESENTED BY

PROF.CHARLES A. KOFOID AND MRS. PRUDENCE W. KOFOID 


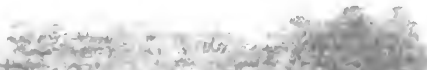

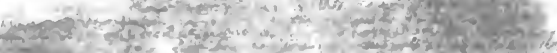

20.

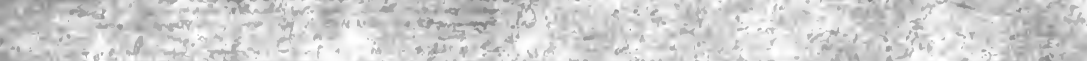

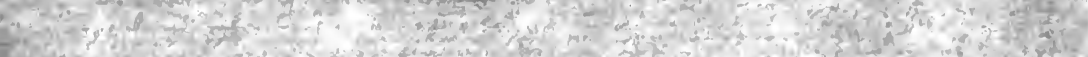
C.

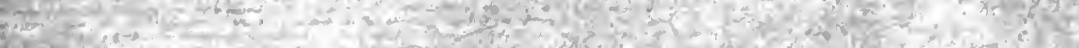

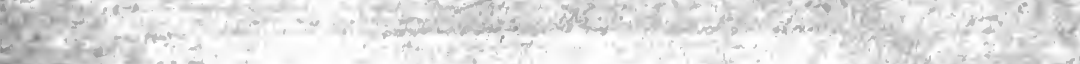

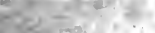
$\cos ^{2}+\infty=$

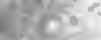
$+2=1$

\section{ass}

1.

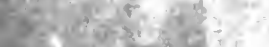

sing in in

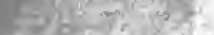

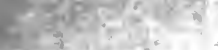

$20+2=t^{2}$

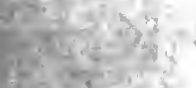

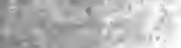

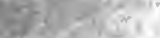

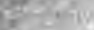

ixt

(2)

2.

8

8

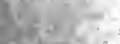

$\frac{3}{6} y^{2}+x^{3}$

sin-

$x^{2}=-2=$

$2 x^{3}=$

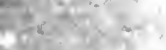

$x^{2}+x^{2}+4$

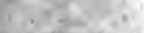

$6+4 x^{2}+1$

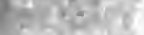

i.

$\operatorname{lin}^{2}$

$x^{2}$

$3+x^{2} x^{+} \cdot 2$

X.s.

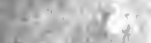

exisest

9xin: $:=$

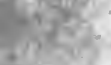

s.

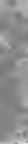

$$
\frac{1}{2}
$$

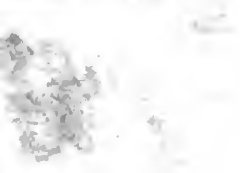

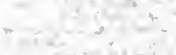

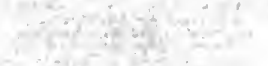

? $+3=$

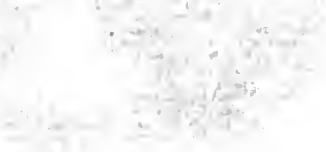

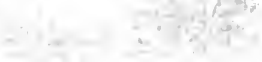

$1+10$. 
Digitized by the Internet Archive in 2007 with funding from Microsoft Corporation 
RECOLLECTIONS OF ADVENTURES. 




$$
\text { f }
$$




\section{RECOLLECTIONS OF}

\section{ADVENTURES}

\section{PIONEERING AND DEVELOPMENT}

IN SOUTH AFRICA

$1850-1911$

BY

H. W. STRUBEN

Revised and Edited by his Daughter Edith

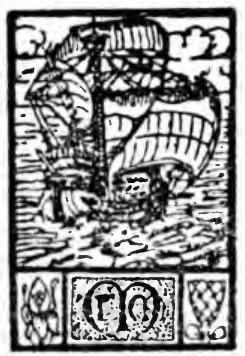

T. MASKEW MILLER, CAPE TOWN

BASIL BLACKWELL, OXFORD, ENGLAND. 



\section{DT 775 \\ ST}

\section{CHAPTERS.}

PAGE

I. The family-Early days in Natal 1

II. Captain Struben and the Natal Magistracy - $\quad$ - $\quad$ - 8

III. Captain Struben requisitioned to become first President of the Orange Free State - $\quad$ - 15

IV. Boyhood days in Natal - $\quad$ - 18

V. Early Pretoria Days _ _ $\quad 27$

VI. Pioneers' difficulties of Travel - 32

VII. Trekking to Cape Colony, 1857-8 - 37

VIII. Big Game Shooting Trips - 41

IX. Hunting Buffalo - $\quad$ - $\quad 47$

X. An Unlucky Trip - $\quad$ - $\quad$ - 58

XI. Giraffes-Lions and other game - 62

XII. An Unpleasant and Adventurous Ride - $\quad$ - $\quad$ - $\quad$ - $\quad 68$

XIII. Bushveld and other treks - $\quad$ - 74

XIV. Hyenas-In a cave and elsewhére $\quad 81$

XV. Zoutpansberg, and Ivory Trading - 85

XVI. Alex Struben's trip to Zoutpansberg and Zambesi - - 
iv.

Chapters.

PAGE

XVII. Boer Voortrekkers and Commandoes 94 XIX. Commandoes and Civil Wars - 102 XX. British \& other European Pioneers and Visitors to the Transvaal -

XXI. Early Farming Ventures and Struggles - $\quad-\quad-\quad-115$

XXII. Native Wars and Unrest - $\quad$ - 121

XXIII. Discovery of Diamond FieldsEarly Kimberley Days — 130

XXIV. Gold Discoveries at Lydenburg - 137 XXV. First Sekukuni War, and fall of

President Burgers $\quad-\quad$ - 141

XXVI. Annexation of the Transvaal - 148

XXVII. Zulu War of 1878-79 - _ - 154

XXVIII. Travels in Europe, 1880 - $\quad$ - 160

XXIX. Return to South Africa and First

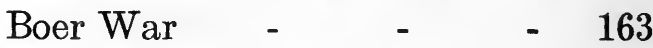

XXX. The Retrocession - $\quad$ - $\quad$ - 174

XXXI. A General Survey and Summary

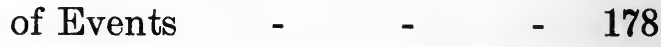

XXXII. Discovery of the Witwatersrand

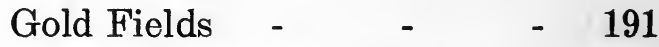

XXXIII. Afterword and Last Years _ $\quad 203$ 


\section{INTRODUCTION.}

At the request of my life's friend and dear companion, my staunch, loving little wife, and our dear children, I have given myself the task of writing a resume of facts and incidents which have come to my knowledge during a residence in South Africa since August, 1850.

I will avoid personalities as much as possible and will merely mention the part $I$ have taken personally in the works of development, especially in the Transvaal, to give an idea of the position from which I have viewed passing events. I have avoided statistics which have been amply supplied by blue-books, newspapers, and other writers. I have tried to condense this synopsis, and find that it has, nevertheless, grown in dimensions far beyond what $I$ intended, and yet a vast amount of pertinent matter had to be left out, and I find that although most distasteful to me, in writing from memory of personal experience, the " Ego" is unduly prominent if perhaps unavoidable.

As regards what I have written about the Transvaal during a residence of thirty-five years from 1855 to 1889 , and since then in annual visits till 1910, I would mention that I closely identified myself with the civil and political life of the Dutch farmers or Boers. ("Boeren" as they are usually termed), with whom I was on the most friendly footing, and with whom I worked in various capacities, as Member of Volksraad for the district of Pretoria, 
as President of the Land Commission, as first Director of the Delagoa Bay Railway, 1875-76, as first Chairman of Mines, Witwatersrand, (Johannesburg) etc., etc. Although advances were made to me, but being (as a member of the Legislature) pledged to the country, I took no part in the annexation of the Transvaal by Sir T. Shepstone in 1876-7, and during the term of the British occupation I held no office of emolument, and I refused the offer of the first seat in the Executive Council made me by $\mathrm{Sir}$ Bartle Frere. I had among the Dutch Afrikanders many friends at the time, and I fully appreciate the good qualities they possess. Although in my absence in Europe and the East, during the war of 1880, I was treated as one to be distrusted, an English alien, and half ruined, I can conscientiously say that I am not prejudiced against the Dutch Boer, and I trust that any statements I have made will be accepted as dictated by an open mind, without animus and being correct as far as my memory serves, and in remembrance of many acts of kindness received, and of mutual friendship during years of strenous effort and of vicissitudes in a young country ; playing the difficult role of a pioneer of civilisation in remote regions on a savage borderland.

ROSEBANK,

\section{CAPE OF GOOD HOPE,}

February, 1911. 


\section{Chapter I.}

\section{A WORD ABOUT THE FAMILY.}

\section{EARLY Days in ENGLAND and Natal.}

My father, Johan Marinus Struben, born in Oosterwijk Castle in Holland, 30th March, 1806, was married on the 2nd of May, 1838, to my mother, Frances Sarah Beattie, a daughter of Alexander Beattie, Esq., who was born in Scotland, and was later a landowner in Hampshire, and Consul for several nations at Cowes and Portsmouth, and a shipowner.

Our grandfather Beattie owned at one time several ships trading with the West Indies, where he had interests in sugar plantations. $\mathrm{He}$ lost heavily during the Napoleonic Wars and owing to loss of vessels, under convoy in a gale, and also to the deterioration in value of West Indian property when the slaves were emancipated and land went out of cultivation.

The Poet Beattie was a cousin of my grandfather's. Lord Byron was a friend of my grandfather Beattie, and stayed with him before he left for Greece. Letters of his written from Missalonghi were destroyed during the Transvaal War of 1880 , together with many other papers and things.

In 1840 my parents, who were travelling on the Continent visiting Germany and Holland,

Captain J. H. M. Struben became a naturalized British subject when he married Miss Beattie, and went to reside in England. We have the Letters Patent signed by Queen Victoria.-(Editor.) 
were prevented from returning to England in the Autumn as intended, owing to circumstances over which $I$ had no control, and I was born on the lower Rhine (where my father's yacht Fanny was lying) on October 9th, 1840, and christened in the old Cathedral of Rotterdam, Hendrik Wilhelm Struben. All my brothers and sisters were born in England, (with the exception of Fred, who was born in Natal,) and were christened in the Church of England.

For some years we lived in Cowes, in the Isle of Wight, my father was Consul for several nations, he was a member of the Royal Thames Yacht Club, and owned a small yacht of 39 tons named Fanny after our mother, (No. 40 of the Royal Thames Yacht Club). As a boy I remember many pleasant sailings round the Island, and on the South Coast and occasionally trips were made to Holland to visit relations.

My father had for years voyaged to the East, at one time in command of a small squadron of vessels, employed by the Dutch East India Company, for correcting the charts of the Straits of Malacca, Sunda, round Borneo, the Chinese Seas, etc. He had voyaged all over the world and led a most eventful life. I have still the Cross for Valour he got for carrying dispatches to the Citadel at great risk during the siege of Antwerp, when only a Lieutenant.

He was twice shipwrecked, being once for three days with eight others on a mast in the North Sea, who all dropped off but one of his seamen and himself, and both when picked up were nearly dead. $\mathrm{He}$ never quite recovered from the effects of this adventure. He was a friend of the first Rajah Brooke of Sarawak, and subsequent to his marriage 
he still made voyages, as captain of vessels to India and China when my mother went to live near London, and sent the elder children to school. My mother's health was very delicate and the doctors ordered her a change to the Cape, so in 1850 we sailed in the Old Anne, a teak-built East Indiaman, which has been captured from the Dutch in Saldanha Bay in 1806 and re-christened. She was of the old galliot "bowed" class, and took three and a half months to reach Table Bay. She was chosen for our migration because Captain Clinch was an old friend of my father's in Hong Kong. He gave us the whole suite of spacious and comfortable state cabins. I remember (when becalmed in the tropics,) watching the great blue sharks from the cabin windows lazily swimming under the stern, waiting for food.

A dear good friend of my parents, Captain Castle (who so nobly distinguished himself when his ship was burnt at sea,) exchanged into the Old Anne as first officer, so as to be of assistance to us on the voyage; he went on to India, and I never saw him again; he died a few years ago in Devonshire. After sighting the Cape we were terribly mauled in a gale before we could get in. There was no Table Bay breakwater then. I remember, that Port Captain Wilson gave me a fine Newfoundland dog, that used to swim after penguins, which were then plentiful in the Bay. My mother's first trouble on landing was, that the better looking of the two servants immediately got married to a man who had courted her on the ship, while she was pretending to be too ill to do her work! While we were at the Cape the Van Reenens and other old Cape families were very kind and made the short visit pleasant, but we did not stay long, as Sir Benjamin Chili Pine (whom my father had known in the East), who was then Governor of Natal, persuaded him to accept an 
appointment as Chief Magistrate over the Northern portion of that Colony, embracing four sub-magistracies. The bar of Durban harbour was then too shallow to admit of large ships entering the bay, and I remember my mother being shocked at the nude Kaffirs in the cargo boat which landed us. After the grand old East Indiaman we had a rough experience in The Fliberty Brig from Cape Town to Durban, (a pokey little ship.) The old Scotch Captain told us that the fires we saw on the coast were made by the farmers burning down their homesteads; which they did yearly to destroy the bed bugs known as "Norfolk Howards"! I have been in many houses since then, in which the swarming insect life would fully justify such drastic measures; but when I have complained I have been told that they always attack strangers, the ordinary home dwellers being immune!

Durban in August, 1850, was a straggling village with neither streets nor sidewalks, only stretches of white sand, dotted with grass-thatched bungalows. The best house belonged to Mr. Harry Milner, which he kindly placed at our disposal during our stay. It was pleasantly situated under shady indigenous trees on the Bay front, near Cato's Creek. Harry and Tom Milner and many other nice people were very kind; my father and mother being favourites. There was a good class of gentlefolks in the Colony who understood real hospitality and were glad to welcome new comers.

Dr. Stanger, the Surveyor-General, was going to Pietermaritzburg in what struck me as a large clumsy tented wagon, and we joined the caravan. I was only a small chap and was proud when I was given a horse to ride the whole way. At the halts I got stiff and sore but would not give in, so I 
arrived in Maritzburg minus some cuticle though proud and happy! The old Boer road over the mountains, overlooking the Inanda location, afforded lovely views, now the railway follows closely the same route but one sees much less when rushing along! In those early days of the Colony everyone was full of hope and energy and belief in the future of the country. The whole tone of the upper class whites was superior to what it is now, and the natives were happier, less impertinent, in a sense less civilised, but in every way more agreeable and self-respecting ; while more respectful to those in authority than they are now, since their intimacy with low class whites, and their having attained to a certain degree of education, and a change from the simple native life and customs.

Maritzburg was then a straggling village, mostly built by the Dutch, before the Colony was taken over by the British in 1842. We had a house close to Government House, and next to Zeederberg's Mill, which was worked by an overshot waterwheel on the main water furrow. Open water courses traversed the streets and irrigated the gardens.

Sir Benjamin Pine, the Governor, and Mr. Theophilus Shepstone (afterwards Sir Theophilus), Secretary for Native Affairs ; Judge and Mrs. Cloete, Dr. Stanger, Surveyor-General ; Mr. Donald Moodie, Secretary to Government, Dean Green (then Military Chaplain), the Rev. and Mrs. Campbell, Mr. and Mrs. Bird, Colonel Boyd and the officers of the old 45th Regiment, and many others I recall with affectionate and vivid remembrance. For a time, my elder brother Alex and I went to a private school kept by a Mr. Walker (near old Colonel Boyd's), the other pupils were Henriqúe, Willie and 
Offie Shepstone and Graham Cloete. What is now the Prince Alfred Club was Judge Cloete's house, and I used often to spend my Sundays there. Those old days were happy ones, and I have a warm corner in my heart for Natal, although so changed, and I feel sad when I think of how few of the old friends are left, how many hopes have been unfulfilled!

When our parents went to the up-country Magistracy we two boys stayed with the Rev. and Mrs. Campbell, and I shall ever remember them with affection. My father's faithful Indian body-servant, who had been with us for fourteen years, returned to Calcutta, as he did not like the Kaffirs. He was a great loss.

When we went to Ladysmith we had to live in native grass huts, while the house was being built. One night an ox pushed his horn through the grass near my mother's bed and gave her a fright! Another moonlight night I saw a large hyena prowling in front of the hut door. When the big house was built, we had constant visitors, the Governor with his suite, horses and orderlies, officers on leave, up for shooting, and I was told off to show them game, and do a little on my own account. We often had visitors from Europe and elsewhere. Bishop Colenso was also sometimes our guest. Our house was never empty, and had my father not been in receipt of small sums from Europe, he could never have entertained as he did, on the paltry salary then allowed Colonial Magistrates.

A Captain Shelley and Dr. Harvey were staying in Ladysmith on their return from a shooting trip to Bamangwato and the Ngami Lake. They were jovial fellows but reckless, and had their travelling wagon and servants. One day for a bet Shelley 
said his duelling pistol could reach the wagon, he fired, and the ball went through both sides of the wagon, missing his white servant Webber by an inch as he lay on the bed! Another time he was shooting gin flasks off Dr. Harvey's head. Without intending to tell tales, I mentioned this as a great feat! My father thought otherwise and stopped the game, and they were angry with me for telling. Shelley afterwards commanded a Turkish contingent in the Russo-Turkish war.

One hot day I was escorting a "la-di-dah" swell sportsman, just out from home, shooting guinea fowl, when, overcome by heat he suddenly sat down on what he thought a soft spot, but was really a species of euphorbia (which grows in the form of a cushion on the ground) and is one mass of prickly spines. He rose with a yell and all the way home used profane language, condemning Africa for providing such a fiery seat of honour! 
CHAPTER II.

\section{CAPTAIN STRUBEN AND THE NATAL MAGISTRACY.}

During the period 1851-54 the witch doctors in Zululand were "smelling out" native kraals wholesale, and the slaughter of men, women and children was dreadful. Thousands were drowned in the Tugela, and stabbed on its banks, while trying to cross into Natal, but yet many succeeded in reaching safety there. My father did not think it advisable to augment the existing Natal tribes living in locations, so apportioned these refugees, (who had nothing to live on,) in families among the Dutch farmers for a term of years, on most favourable conditions, food and land being found them and their families, while the men did a certain amount of farm work for the owner. The Governor approved of the scheme, and the Natives and Boers were both satisfied. These Zulus are now well-to-do and have increased alarmingly. It was the best that could be done at the time, the poor creatures could not be driven back over the Tugela to be butchered, and they were starving. Nevertheless, a missionary wrote to the authorities in England, that Captain Struben had handed over these people to the Boers as slaves, and one of the Natal papers which has always been a thorn in the side of the Colony, took up the cry and heaped abuse on my father and condemned everything he did. At another time a tribe under Gado-gado living in the Drakensburg used systematically to steal the Natal farmers' cattle, exchanging them with the Basutos for cattle stolen 
in the Sovereignty (now the Free State). Gado-gado was ordered to appear before the Magistrate to answer to these charges. He answered that if the Magistrate wanted him and felt strong enough he could come to his location and fetch him! If order had to be maintained, such a challenge could not be allowed to pass, so my father with one of his subordinate Magistrates, the late Dr. Blaine, the Field Cornet, Martinus Koekemoor, a Boer by name Jan Groen, with a body of native police approached the head "kraal" from the mountain side at daybreak. A woman gave the alarm, and the Zulus rushed out armed with assegais. One aimed an assegai at my father's chest, but the horse threw his head up and received it on the bone of the neck behind his ear, where it bent and hung, the horse turning round and round in his fright. The Kaffir then rushed up with a stabbing assegai, so my father shot him dead with a pistol. Another rushed at Dr. Blaine who also shot him, and then a general scrimmage took place, thirty-two of the rebels were killed and wounded, and the tribe taken prisoners to Ladysmith. Again there was an outcry by some missionaries supported by the same paper, that "cold-blooded murder had been committed, and that Captain Struben should pay the penalty." The Governor and most of the officials stood by him and I have letters approving of his conduct, but the enmity against him was extreme on the part of the one paper and the missionaries.

Up to this time cattle were a drug in the Natal market, oxen being as low as $£ 1$ and even $10 /$ - each, but pleuro-pneumonia had been imported to the Cape from Holland, and notwithstanding that my father placed guards at the passes in the Drakensberg, the terrible disease entered Natal and destroyed two-thirds of its cattle. The cattle 
taken with Gado-gado caught the "lung sickness," and died wholesale, and my father's enemies again accused him of appropriating the cattle taken with the rebel tribe. I believe that this unwarrantable animosity was due to the idea that my father sympathized too much with the Boers, who greatly respected and liked him.

At another time, Nodada, a chief ruling in the Umsinga location refused to deliver up a murderer who had taken refuge with him. My father with his interpreter, Iomtye, went to Nodada's head kraal, where a large number of the tribe were assembled, and among them the murderer. Under tribal law the chief is answerable for individuals of the tribe, and it was his duty to send the murderer for trial to the Magistracy when ordered. My father demanded his immediate arrest, when Nodada refused, he held his pistol to his head, took out his watch and gave him five minutes to decide. Nodada immediately called to his people to catch the man, which was done, he then held his hand out and said to my father, "You are not an old woman like some, you are a man. I respect you and you will never have trouble with me again," and he kept his word. When the Basutos broke out some time afterwards and my father was asked for a native contingent, Nodada was the first to offer his assistance, and a grand lot of fighting men they were in their war dress, plumes and shields, each regiment carrying differently marked oxhide shields. Four thousand went to the front from the Klip River division, and I was fascinated by their thundering war dance, which they performed before my father, giving the salute "Inkosi Bayete."

During the early Zululand troubles I was sent to Commandant Karl Landman, in the Biggarsberg, 
with orders, post haste, as another inroad of Zulu impis, ( following refugees into Natal) was expected, but the Tugela rose, and the unfortunates that did not succeed in swimming across were assegaied or drowned, and the impis did not cross. Landman lived near the Zulu border, and in the long ride my trousers split, and I felt much disconcerted when I saw a lot of girls looking at me from behind a door curtain, shrieking with laughter at my sorry condition. The old lady of the house gave me a needle and thread so I retired and repaired the most conspicuous rents, but I hated those girls, and after getting my dispatches and supper, rode back, as I would not sleep there. On the road back, my horses were tired, so I slept in a reed enclosure at a Kaffir Kraal. While lying down, a large yellow snake came close to me and I was preparing to kill it, when the head man ran up and begged me not to hurt it, said that it was harmless and was their good genius, and if it were killed the "Umtagati" (witches) would ruin them. I afterwards often saw these orange coloured snakes in Kaffir Kraals where they are protected and fed.

I used to enjoy going into the native locations with my father and his staff, collecting hut $\operatorname{tax}(7 / 6$ per dwelling hut was the tax), but the Kaffirs had then little or no money and paid in cattle. This was inconvenient and risky, as animals ran away, or died, so that the Government would only allow 7/6 (or tax for one hut) for the largest ox or cow, and I bought several fine animals for $10 /$ - each. Two of the oxen I trained to ride and used them as pack animals for carrying game, and riding about the farm and later took them to the Transvaal with me. We saw at Matyana's ("Job's Kop") location eight hundred fine oxen all brindle greys ("Blaauw- 
schimmels") which the chief had paraded in front of us as a mark of respect. One night in Dobenkulu's location the Kaffirs were, within a short distance of our camp, fighting among themselves, so I did not sleep as well as usual-there is nothing so conducive to wakefulness as "blue funk."

The country along the middle Tugela is very rugged, full of deep kloofs into which the Kaffirs used to throw their broken huts before the Magistrate came tax collecting; we found this out and fined delinquents double. After the tax collecting was over they rebuilt the grass huts; all that waste of energy for $7 / 6$ ! This locality is wild and beautiful, lower down Bambata made his stronghold in 1906. These locations are fertile and the Kaffirs live a careless easy life, working very little.

My father established a system whereby each Kaffir chief supplied a percentage of his tribe for making and keeping in order the public roads in his district. The Kaffirs were well paid, well fed and were as happy as "mudlarks," but again the troublesome newspaper and the missionaries raised a cry of "slavery," wrote to England, and my father received orders to dismiss them, as a Liberal or Whig Government would not tolerate "forced labour." The roads have never been so well kept since. These road parties were under Mr. Duncan MacKenzie, the father of the present Sir Duncan MacKenzie who has done yeoman service for Natal during the wars.

The Bushmen used to come down the Drakensberg passes and steal droves of cattle, stabbing with

Note by Editor.-This system of road-making is very successfully followed by the British in Uganda. The Native Chiefs under the administration are responsible for the roads-which are beautifully kept and remarkable in such out-of-the-way placeswhere in these days of a no longer "Dark Continent" motor traffic is frequent. 
poisoned arrows all that would not travel fast enough when on the retreat. There was a military post at Bushman's River (now Estcourt) and some pleasant officers were there, commanding mostly Cape Corps (Hottentots), they were splendid riders and rifle shots and most interesting chases after these Bushmen raiders took place. How long ago it all seems !

One night my father's horse came home alone, saddled, so, knowing which road he had gone I took Berry, our white man-servant, some brandy, and some Kaffirs with a stretcher and lanterns to look for him. I found him near Elandslaagte (the scene of the fight in the last Boer War) about midnight. He was lying on the hard road with his hip injured, the horse, a wild brute named "Bushman" having shied and thrown him in the dark. We carried him home; but he was laid up for some time, as the same hip had been hurt once before when he was shipwrecked in the North Sea.

The Boers had a great admiration for my father's courage, energy and determination, and as he could do more with them than anyone in Natal, Sir Benjamin Pine trusted him implicitly. When in 1853 the Government wanted a census taken he had great difficulty in overcoming the fears of the Boers, who got an idea that they would be enrolled as soldiers, and also that ill luck would come to them, as it did to the Israelities when numbered in Canaan. Shortly afterwards a "trek" was organized to go to the "Land of Goschen," and he dissuaded many from joining by showing them maps and explaining where Egypt and Goschen really were; but some went to the Transvaal, where they settled, as they found the Limpopo district and Matabeleland impossible. In those days the Boers thought that the "Mahalaquena "River was the source of the Nile, as it flowed 
north and from the vast numbers of Ibis, Flamingoes and waterfowl in the marshes, they called it the Nile (Nylstrom). I was astonished at the myraids of waterfowl, spurwing geese, teal, widgeon, coot, divers, herons, etc. when I first saw them. In 1856-7 it was full of water, but when I saw it again in 1909, it was dry at the "Moord Drift" and below at Mapela's old kraal it was sadly shrunken and most of the waterfowl gone.

My father was chiefly responsible in negotiating (through Sir Benjamin Pine), with Earl Grey and Sir Harry Smith to get proper titles for the Boers who occupied farms in Natal, for which they were most grateful, as they had been told by mischiefmakers that the British Government would not give them titles, and would eventually take the land from them, they wanted to trek out of Natal but he persuaded them not to.

It is pathetic when one thinks of the hardships these poor uneducated picneers have so bravely endured, in their endeavour to make a home after their ideal in South Africa, and although they have been misled by adventurers and shown distrust of, and intolerance to, "Uitlanders," one must sympathize with them, their aspirations dashed to the ground, many impoverished, many pauperized, and the black races they conquered being placed in a position to wedge them out of existence. When I remember the old days, when I was trusted and respected by them; before the Annexation of 1877 (after which every Englishman was distrusted whether he had taken part against them or not), I feel deeply that much is to be said on their behalf.

In the fifties there were many fine old English educated gentlemen in Natal as Government officials, men you could respect and look up to. 
CHAPTER III.

CAPTAIN STRUBEN REQUISITIONED TO BECOME FIRST PRESIDENT OF THE ORANGE FREE STATE.

On the 17th April, 1854, my father received a requisition signed by members of the Volksraad of the Orange Free State to allow himself to be nominated first President, after the Sovereignty was given back to the Boers at Sand River. The signatures are :-

I. J. Janson van Rensburg.

A. J. Enssen.

P. L. Moolman.

G. Viljee.

C. J. C. du Toit.

Joseph M. Orpen.

H. J. Nalser.

E. Haines.

The Governor did not wish him to leave, so nothing came of it.

On the 3rd May, 1854, a letter signed F. P. Schnehage, Acting Landdrost, Winburg, by order C. v. d. van Soelen, Government Secretary, again urged him to become President and promised that the Volksraad, which would sit on the 27th May, would give him their full support and would write him to that effect but it was too late, and Mr. Boshoff was appointed in 1854. In the Natal Independent and General Advertiser of May 4th, 1854, the 
farmers of Upper Natal sent the following memorial to the Government of which the literal translation reads:-

"We, the undersigned inhabitants of the Division of Klip River, having learnt to our inmost grief and heartfelt sorrow that our beloved and respected Magistrate, Captain Struben is likely to leave us, having been $\mathrm{n}$ minated a candidate for President of the Orange River Free State, at the forthcoming election, and letters from the Council and others high in office in those parts having been forwarded to Captain Struben, assuring him of their influence on the people to obtain their votes in his favour-most humbly yet most urgently call upon His Honour the Lieut.Governor and the Council of Natal to adopt such measures as will tend to avert the threatening calamity, and to guard not nly our division, but the whole district against an evil, which according to our conviction will be keenly and long felt, and if not averted in proper time must lead to the ruin of this district; we, therefore, do not for a moment hesitate to propose to the Government not to accept Captain Struben's resignation in case it be tendered, but on the contrary to double his salary."

"To His Honour the Lieutenant-Governor and Council of Natal."

This was signed by nearly everyone in the district. In the Natal Mercury of May 10th, 1854, I find-"The Orange River Free State (late the Sovereignty). We have good authority for stating that Captain Struben has signified his willingness to accept the office of President to which we doubt not he is, before this time, formally appointed. Although 
it will be perhaps impossible to find a successor to Captain Struben in the Magistracy of the Klip River division, in all respects his equal, we consider this appointment, on the whole, is a fortunate circumstance for Natal as well as the wisest step that the Council of the New State could possibly have taken. The prestige of Captain Struben's name and character will keep the native tribes in wholesome subjection, whilst it will have the effect equally and simultaneously of inspiring the confidence, and harmonizing the forces of the Boers and the British settlers."

In the Natal Independent and General Advertiser of May 4th, 1854, appears the following :-

"The Sovereignty and Captain Struben."

"It is now talked of everywhere and has become a matter of such general report that we can no longer doubt the acceptance of Captain Struben of the Government of the Sovereignty. Indeed, we do not deduce any reason to doubt the alleged fact, while ten thousand reasons may be adduced in favour of such an arrangement and to render it highly desirable." 


\section{CHAPTER IV. \\ BOYHOOD DAYS IN NATAL.}

One of the most enjoyable years of my life I spent with Mr. Posselt, the head of the Berlin Missions in South Africa, at Emmaus, near the Umlambonja River under the Kathlamba (Drakensberg) near the Mont aux Sources. My dear brother Alex. was with me and a lovable and charming companion. Dr. Blaine's son Fred, now Sir Frederick studied with us, German, Latin, English, Zulu, etc., etc. Mr. Posselt was an upright gentleman, kind and considerate, and I shall always remember him with affection. Mr. Posselt's brother-in-law with wife and children were crossing the "Inja Suti" ( full dog) "The Little Tugela" when a mountain freshet came down, carried wagon and oxen away, and the poor people were drowned. $\mathrm{Mr}$. Posselt was in Xosaland during the early Kaffir wars and had to flee with his wife and child in the night, being warned by some of his native pupils. After he left Emmaus he was minister to the German settlement at Pine Town.

The thunder storms along the Berg were terrific sometimes, and there were often fatalities by lightning. One Sunday an old Boer and his wife were sitting in front of their house on the next farm to Emmaus, when the lightning killed him in his chair. Whilst we were at Emmaus the great snow storm of 1853 occurred; the game came down the Berg in vast droves from the high table lands of the Free State, and tens of thousands died in the mountain ravines 
and snow drifts. The farmers and Kaffirs lost heavily in stock, and the whole country was full of dead birds and small game. The snow in the low country melted after several days; but the mountains were covered for months. The locations of Hezikali, Putini, and Langalebaleli along the foot hills of the Drakensberg under Cathkin Peak, Giants Castle and Mont aux Sources, are in grand country. To watch the thunder storms gather in these mountains, (12,000 feet high) and travel eastwards over Natal is a treat indeed for those who love nature as I do.

My grandfather sent some money to buy a farm for Alex. and me, and my father bought one near the Tugela, and named it "Ruitenburg" after an old castle in Europe. The land joined Pieter's Hill on the South East and Wagonhill on the North West, where afterwards there was such hard fighting in the 1899 - 1902 Boer War. I farmed the place after a fashion but did not make much of it. We made a winding path through a beautiful grove of trees along the hill, with a summer house at the end for our dear mother, but I feel sad when I remember how little she was able to enjoy it, her health being so bad. We built a large house of free stone cut by German workmen. I hear that since the war the place is in ruins. We sold it years ago.

Alex. and I used to have delightful rides among the mountains on wiry little Kaffir ponies hired by the day. There was splendid fishing in the clear mountain rivers and we bathed so much that we all became expert swimmers. I have caught golden carp in the upper reaches of the Tugela, the "Umlambonja" and "Minnowenu" up to 10,11 and $121 / 2$ lbs. The Natal rivers are now stocked with trout. 
Below the Tugela Falls I caught large eels of 14 lbs. weight where General Buller's column crossed to attack "Pieters Hill."

My sister Rose was a splendid swimmer, and could cross the river in high flood with ease, we were all as at home in water as on land. The Zulus are powerful swimmers and fond of water-they bathe whenever they can-not like the Bechuanas and Makkatees who generally dread water.

I was fond of animals, and among others had a large tame "Hartebeest." $\mathrm{He}$ used to amuse himself by hooking any clothes or linen (out to dry ) on to his horns, and careering about the Ladysmith village, to the amusement of those to whom the linen did not belong. One day he stood with his back in the door of the Dutch Church at "Nachtmaal" time and knocked over a couple of churchwardens. I was sent for, and with a policeman or two got him away, but I was told that he must not be allowed at large; so I sold him. I used to go to Tommy Wright's the butcher, for meat for my dogs. There was a town regulation that Kaffirs must be clad while in town, so Tommy told his boy to take the meat, but to dress himself, as he was going to the "Inkosi's" house. The boy dived into his hut, reappeared with one of Miss Wright's corsets on, hind side before, shouldered the meat and came with me; in the garden we met my father who asked what I meant by bringing a naked Kaffir to the house. I explained that the Zulu thought himself in full dress, and how the dear old man laughed!

One day when we were at the Camp on the hill above the present bridge, a wind storm took the roof off the chapel, seized a wagon, and a cart and blew 
them into the river. Once on the way up to Ladysmith while outspanned at Moord Spruit, (where so many Boers were killed by Dingaan's Zulus,) we were caught in a terrific hailstorm. The oxen bolted, one had his eye knocked out, the Hottentot driver, Christian, made a Zulu boy go out to turn them, he was knocked down and stunned before he got a hundred yards, Christian had to drag him under the wagon, and when we did go on, the Blaauwkrantz River nearly washed us away.

In the winter Alex. and I used to hunt quagga, wildebeest, hartebeest, blesbok (gnu), that came down the Berg for the winter pasturage. The flats towards Spion Kop were full of them, a few buffaloes were still on the Tugela, and numbers of eland in the Drakensberg. The game used to invade Natal during cold weather in thousands, and two Scotchmen started a factory on the Buffalo River near where Newcastle is now, to boil down their fat for lard; thousands were killed, especially quaggas to supply the demand. Quaggas are $\mathrm{n} \mathrm{w}$ extinct. This district was subsequently given out under occupation grants, and is now inhabited by Boers, English and Kaffirs.

Some years later Mr. MacKenzie was repairing the Tugela Drift with a party of Zulus. The river was strong and a Makkatee boy of mine who was driving oxen missed the crossing, and was nearly drowned. I swam to save him, he clutched me round the neck, we both would have been drowned had not MacKenzie sent some Zulus to our rescue. These Zulus were angry with the boy for clutching me, and kept on ducking him when they got to a sand bank so that the poor wretch was nearly dead. Old MacKenzie gave me a scolding for risking my life for a Makkatee when his Kaffirs could have done 
better for half-a-crown. Ted and I used to go about the hills overlooking the Tugela. There were crowds of baboons, and one day while we were bathing, they stole some green mealies we had left on the hill above, so we lost part of our lunch. How we enjoyed those rambles !

The Klip River being in high flood, Alex. and I and our Zulu commandeered the ferry boat belonging to old Adams the blacksmith, and gaily rowed down stream. All went well until we got into the big rapids above Cauvin's Mill, (in the Poort opposite Umbulwana,) when we struck some rocks, got twisted about, and half filled with water, but succeeded in landing at Cauvin's, where we hired a cart to drive home. Old Adams was unreasonably put out; but we paid for a wagon to fetch the boat back, and there was a reconciliation. There is a large pool in the river above our house with a rapid shooting into it. I was bathing when I saw a man wash down into the pool, I swam to help him out, but he was dazed and tried to grapple me, so I hit him between the eyes, caught his "back" hair and held him up while we drifted with the stream. Fortunately, our stable boy (who was watering the horses), a splendid swimmer, jumped in, and helped to get the fellow out. He turned out to be a half drunken Irish bush sawyer, and he no sooner recovered, then he wanted to fight me for hitting him in the eye. There's gratitude for you! There were no bridges in the fifties; so travelling was dangerous, as the rivers filled so rapidly from the mountain rain storms.

One day while shooting on Ruitenburg, I heard my dogs barking, on getting near saw a large, black snake swinging from a branch spitting at them. I shot him, but all the dogs went blind and remained so for some time. These mountain snakes 
killed 13 of our cattle; some died before they reached the kraal. The Kaffirs declare that snakes are fond of milk and suck the cows to get it. I had two grand dogs, Gyp and Smut, crossbred Scotch stag hounds, and many a wounded buck and antelope they accounted for. I took them to the Transvaal, where Gyp was killed, she was found with her jugular vein torn open, with dead baboons which she had killed before they mastered her around her. This was on Louw Pretorius' farm, on the Pinaars River below Bairaam's Poort. A fine pup of hers which stood level with the dining table, I lent to Will Skinner and Lewis Devereux on their big game hunt. A crocodile caught him in the Limpopo.

When the grass fires started I used to get the Kaffirs with throwing "kerries" and have a fine game drive at night. There were reitbuck, vaal and rooi reebok, oribe, duikers, steenbok, red hares and a very large kind of dark hare with a spot on its forehead which gave fine sport. The Kaffirs named him "Woguacha," the red hare "Intenetceha." We used to keep the house in fish and game.

Once my father and I called at Casper Labuscagne's on the Tugela near Spion Kop. We found him in bed with bones broken and badly mauled by a buffalo which had got among his herd of cattle and charged him without warning. I afterwards bought Spion Kop and put Ted on it with a herd of cattle, but disposed of it again, as the Kaffirs on the adjoining land-colonization farms make living there impossible. This letting of farms by Natal companies and large land owners to Kaffirs is ruining the Colony, and the finishing touch is the coolie invasion. Ladysmith is now a coolie town, the white shopkeepers and tradesmen are gone, crowded out by the Asiatic. Ladysmith once did a large trade 
with Mauritius and the Cape in butter, Messrs. Knight \& King at first sent thousands of casks away, but the Boers made it so badly, that there was soon no sale for it, and the trade died. Splendid Zulu boys' wages were $7 / 6$ a month and mealies; and they were cheerful, healthy and willing workers. Now they get five times the pay, wear dirty clothes, are often sickly, and don't like work. Some of our old Zulus followed me to Pretoria, but gradually gave it up as they did not like Makkatees. (i.e. Transvaal Natives).

In those days there was very little money in the Colony; everything was bartered and cheap-mealies from $1 / 6$ to $3 /-$ a muid of $200 \mathrm{lbs}$. Traders or "smouses" (as they were called) brought herds of cattle from the Transvaal and Zululand to add to a plethora in the Colony, and they were almost valueless. The Zulus gave from 10 to 30 cows for a wife, now they take them on the credit system for about a fifth of that, and often fail to pay the poor fatherin-law. I know of a case lately (before the East Coast fever came into Natal) of an old Kaffir buying a young wife for 10 cows. The brother handed them to his father-in-law to pay for a wife he had taken on credit some time before. According to native custom the eldest brother of this damsel took the cattle to pay for his wife and this was repeated once more. The cattle having thus passed four hands in the meantime. The first old "sportsman's" wife took exception to his looks and general decay and "bolted", so, according to native law the cattle had to be returned. This caused much oratory in the four families, but Kaffirs love complications anent their marriage laws, and shout and talk for days. These cases are the despair of magistrates. In the early days gangs of "Intombies" (girls from 15 to 
18 ,) used to parade the streets of Maritzburg, dressed in a fringe of string about three inches deep round the waist. and some brass anklets. Immediately a cry of "Kelegeshla umtwau etu" would be raised by dozens of Kaffir boys, grooms, house boys, shop boys, etc., who would stop the girls in a row, each boy selecting the one which he admired most, the jokes that passed, and the language used from a moral and social point of view left much to be desired. These girls had a great advantage-charcoal would make a white mark on their faces so they could not blush, and unlike Eve, they were naked and not ashamed. They were healthier in the South African climate with "zair nodings on" than in the bedraggled finery and garments many of them now wear.

I love a good horse, and when we lived in Natal we had some of the best; they were cross bred Arabs, grey, standing $\mathbf{1 4 . 2}$ to 15 hands and as hardy in the limbs as they were good of heart and enduring. They came from the Hantam, a district in Cape Colony. One, Snowball, was stabbed in the neck by a Kaffir in a brush with them under GadoGado in 1853 and eventually killed by a lion on the Crocodile River in 1858.

Another, "Flam," after being used as a hunter, and having run down more big game than any horse I ever heard of, was sold to Signor Piavo Raposo of Delagoa Bay and lived in luxury until he died of old age. This class of riding horse does not now exist in South Africa, what with weedy thoroughbreds, ugly floppy Holstein and Flemish brutes, Argentines, etc., it will take some time before Africa

Note.-“Kelegeshla umtwa etu." Lit.: "Go nicely child of ours," which might be more freely translated "How do you do my little dears." -(Editor.) 
can supply herself with really useful mounts, much less export them to India for remounts to the military as in bygone days.

I remember an Englishman, Mr. Evans, a geologist, in 1854 wanted to examine the Drakensberg formation, and I was told off to escort him round. We had a very interesting time; he showed me pebbles and shells on the slopes of the "Berg" which he considered as proof that the ocean coast line had, in bygone ages been there. When we (my brother Fred and I, so many years afterwards) discovered the Witwatersrand water-worn pebble beds, or conglomerates ("Banket"), I remembered this and concluded that the high Transvaal water divide was a still older coast line. There were troops of elands then in the Berg-I believe there are still a very few left near Champagne Castle and the slopes of the Berg. How I did enjoy those delightful rides among the grand, natural scenery.

In 1854 our dear mother died and was buried in the cemetry at Ladysmith. I have made many a quiet pilgrimage to her grave on my journeys from Pretoria to Durban, and have always kept it in repair. The family never recovered her loss. After our mother's death, we had really no home. My father married again and the home was not a happy one for us children. My eldest brother Alexander had always been delicate, he entered the Civil Service and became Civil Commissioner for Durban. Sir Theophilus Shepstone and other of my friends tried to pursuade me to join the Civil Service too, but I was more robust than Alex. and preferred a more independent though rougher life, where I would have more scope for my energies, so I went to the Transvaal with my father and worked there. 


\section{Chapter V.}

\section{EARLY PRETORIA DAYS.}

In 1855-56 I went to study farming with President Pretorius on "Kalkheuvel." $\mathrm{He}$ was kindly disposed but was seldom on the farm and his wife was impossible, a woman with a terrific temper. I found that I was not learning anything, so left one day, after one of her frequent tantrums. The Crocodile River, which runs on the boundary of the farm was in high flood, but she refused me any natives to assist me in getting my cattle across, so I had to do the best I could alone, as it was impossible to remain in the house until President Pretorius' return, nor did she wish it, as she knew he would take my part; as he did when he came to hear of her behaviour, and asked me to try and forget all about it. He was a kind hearted, good man. I could swim very well, so drove the cattle into the crossing, but they were taken down by the strong stream. Some got entangled in the trees; in extricating them I got several bad knocks and bruises, and once or twice nearly gave up, but got them all out after a long struggle; and then had to swim back for my clothes, and, half dead with fatigue and cold, reached old Badenhorst's, where they gave me a "kraal " for my cattle and shelter for the night. Next day I reached Pretoria.

When we first went to Pretoria there was only one Hartebeest house built of poles, reeds and mud where the Pretoria Club now stands. This belonged to Hendrick Vermuelen, the Landdrost, Joachim 
Prinsloo, nicknamed "Tweeduim," (because he had two thumbs on one hand), lived on the banks of the Apie's River, and the Field Cornet, Andries van der Walt, had a cottage near the furrow below Eland's Poort. Messrs. Lionel and Lewis Devereux and William Skinner, who had built a large house for the late General Andries Pretorius on Groot Plaats (a beautiful farm in the Magaliesberg valley) were engaged to build a Dutch Reformed Church in Pretoria, and Mr. Pretorius came and camped in tents, while superintending the making and burning the bricks, and I used to go out with him to shoot "quaggas" as food for the Makkatee brick makers. One day, Mr. Pretorius, who had good horses, and was a good shot, said that any of the party who did not shoot anything was to get ten cuts with a bullock "strop"; in the evening old Franz Schutte, a deacon and leading light of the church was courtmartialled and stretched, while Mr. Pretorius gave him a few cuts, when he shouted so violently that we had to let him go. He left in high dudgeon and never went shooting with us again. At that time the Pretoria town commonage swarmed with Gnu, Blesbok, Springbok and Quagga in the winter, which came from the high veld into the sheltered valleys for warmth, and better grass. I used to go out before daylight and shoot them, as they returned to the high veld during the day time. Poor beasts, they are all gone long ago. It was difficult in those days to earn a living, so I obtained a Government appointment as schoolmaster, but I found it most irksome and only kept on until. I

Editor's Note-Now, on looking from the fine pile of the Union Buildings over the great extent of the town, with its houses situated among their gardens on the many hills-Pretoria, the Administrative capital of the Union of South Africa, would seem to have undergone incredible changes in the 60 years-since this lonely little farmhouse was its sole habitation. 
had earned enough by adding to what I had, to buy a wagon and span of oxen.

Both money and skilled labour were unobtainable in the early days in Pretoria, and when I gave up the Government school, as I had not enough capital to start farming, I started a transport service to Natal in a small way. To economise, I learnt to make my own boots, "veldschoens," to paint my wagon, make " reims " and "strops," to repair wagons and gear. My clothes, except for a suit or two kept for high occasions, made by a tailor in Natal, were built in a most comical fashion by old Mrs. Vermeulen. I soon had several wagons and about 250 oxen, experienced white drivers, and plenty of native servants. I went up and down to Natal several times a year. I shot game for the servants and made "biltong" to last them back into the game country. I sometimes travelled with horse and cart, but during rainy seasons I had to ride the whole distance, alone on horseback, swimming swollen rivers, and riding in the rain on a wet saddle, this brought on rheumatism, which has troubled me more or less ever since.

I had good horses, and enjoyed the sporting part of the business immensely, but at times, with rivers in flood, no bridges, the hard work "trekking" till 10 p.m. and again at 3 and 4 a.m., wagons sticking in morasses, and the thousand and one other accidents inevitable in South African travelling, "it was not all beer and skittles." It was, however, a healthy and free life. I was earning my own living and helping others, and I saved enough to buy the "Willows" and other farms, notwithstanding some heavy losses I had at various times.

When I was staying at President Pretorius' farm "Kalkheuvel," the two Devereux and Will 
Skinner lived on a small farm near by, called "de Erf," and it was a relief to spend quiet Sundays with them and hear one's mother tongue. They were good cheery fellows. Old Mr. Hendrik Pretorius and his kindly tempered wife also made my life bearable at "Kalkheuvel" by making me welcome at "Groot Plaats," whenever I chose to visit them. They knew of Mrs. Pretorius' vile temper, and told me to run over and stay with them whenever I felt inclined. I used to get fine shooting in the Magaliesberg and good fishing in the Magalies River. It is a beautiful district between the Magalies and Witwatersberg Ranges. The river traverses the whole valley, and the land is cultivated on both sides with cereals, tobacco, fruit, etc. I had to go three and four times a year to Natal; and in the winter two or three times to Zoutpansberg, and besides painted all my wagons once a year myself as there were no painters in Pretoria, (and I also saved their charges,) so I was never idle and was quite contented to do all I attempted as well as I could.

In those days (of the fifties and sixties), the spring rains regularly came in September and the winters were colder than they ever are now. The water furrows in Pretoria, and all waterholes and "spruits" were frozen hard, now they seldom are. No one appears able to account for the change.

There was very little money in the Transvaal in those days. The better class Boers used to go every autumn to Natal to sell their produce and get groceries and clothing in exchange. The load would consist of say 10 bags of wheat value $15 /$ - each, tanned leather, ox reims, whips, "sjamboks," giraffe bones, honey, dried fruit and biltong. The average value of the whole load, including a couple of 
oxen out of the span, would not amount to more than $£ 30$ or $£ 40$, and this had to be taken 350 miles by bullock wagon. Very little money passed hands except for ivory or ostrich feathers-the former worth from $3 / 6$ to $6 /-$ per lb.-a good ostrich cock in full plumage with skin complete would be worth from $£ 7 / 10 /-$ to $£ 10$. There were few stores except in Potchefstroom, and afterwards in Pretoria. "Smouses" (itinerant traders), took goods about the country, and exchanged them on the farms for produce, cattle, etc., at about 100 per cent. on cost. The farmer only got from $£ 2$ to $£ 3$ for cows, and $£ 4$ to $£ 5$ for big oxen. Native labour was cheap and better than now, and on the whole, the farmers did as well then as they do now, although there is more money in circulation. I remember one day the wagons had just outspanned at Van Reenen's Pass on the top of the Drakensberg, when some Basutos came along with ponies for sale, and I bought seven at 30/- each and took them to Pretoria.

Old Adrian Standers offered to sell me seven farms on the Upper Vaal River for $£ 75$ apiece in paper money. These farms are now heavily stocked and worth thousands. It is a splendid stock raising country for horses, sheep and cattle, from the Drakensberg to the northern escarpment of the high veld, and should be reserved for occupation of white farmers only. 


\section{CHAPTER VI. \\ DIFFICULTIES OF THE ROAD.}

RIVERS AND THUNDERSTORMS.

In the late autumn it was bitterly cold crossing the Berg and high veld, I think much colder than it is of late years, and the poor Kaffirs and oxen suffered badly in the hoar frost, with the morasses and spruits frozen over. On some trips I had to sleep in the open myself, and felt chilled to the marrow. I soon gave up travelling in the high veld in winter. One trip in the summer I came up with Okker Oosthuizen on the hill north of Bushman's River, now Estcourt. The lightning had just killed his whole span of fine red oxen (14), they were lying in the road in a row. Another time four oxen belonging to my travelling companion were struck, while grazing close to the wagons.

In those days there were no bridges, and the rushing swollen rivers would detain wagons for days, often the loads had to be raised and half taken over at a time, the oxen almost swimming. I have been sometimes for hours in the water getting the wagons over; it was terrible work for us all, but it had to be done. Now "Johnny Newcomes" growl in comfortable railway carriages. People coming to South Africa now, with bridges over the rivers, railways to all important centres, roads made, and hotels at intervals, cannot realize what the risks and hardships of the early days of colonization were. 
Jacobus van der Walt, the same man who drove my wagon home from the commando against Mahura and Gaisbone, was on the road to Natal with a load of ivory for Evans and Churchill. $\mathrm{He}$ attempted to cross the Vaal River at Sand Drift, the water was too strong, and the oxen were swept down below the ford, until only the half of the tent was showing. On this poor Jacobus sat in great fear as the oxen were drowning and he could not swim. I got my men together, and by means of ropes, etc., got him and most of his oxen out, by cutting them loose, but it was a nasty job, and made me ill with rheumatism when finished. I had to attach long chains and pull the wagon out with my oxen, as van der Walt's were no use. One had to be amphibious in those days if you had to travel much.

Some of the drawbacks to the high central plateau are the frightful lightning and thunder storms. During the Basuto war of 1866 , a number of Pretoria people were going in convoy to Natal. They included R. Lys, Brodrick, P. Marais, John Murray, etc., I was elected Commandant to order the travelling, camping, etc. The Vaal River was in flood, and the wagons were camped on the north bank when a terrific storm broke over us. My valuable horse "Trump" was knee-haltered, and I put my head out of the wagon to see if the storm was driving him into the river, when a flash of lightning nearly blinded me. It struck Murray's wagon a few feet away and sent a case of ostrich feathers, which was on top of a load of wool, flying in all directions, then ran down a chain, part of the charge burning marks all over a thick Boer-made woollen hat worn by Dieterickse, who was stunned, and was deaf ever after, until he broke his neck some years afterwards hunting blesbok. Mr. Brodrick took the hat to England as a curio. 
Aletta Vermuelen and her husband, living near Heidelberg, went to Waterfall River shooting. The wagon was fairly loaded with game. They started for home, when the lightning killed the husband, who was driving, and the two hind oxen. The dead man slipped off on to the ground, the wife had no help but a little boy of 10 ; she had to lift her husband on to the wagon, to cut loose the two dead oxen, to inspan the others, after pushing the wagon back from the dead oxen, then drive the wagon about 30 miles home. She kept up bravely until in sight of the house, when she fainted. Her people subsequently found her with her two small children in the wagon at the side of her dead husband. She is still alive, living near the Premier Mine. I have had endless narrow escapes both in Natal and the Transvaal, but have mercifully been spared. The lightning struck a small gum tree on "The Willows" one day, I was writing in my office when I heard the crash, and the rattling of the roof, and ran out to see what was the matter, and found your mother, her old servant-woman Clara, my brother Fred and my man Postill, all more or less dazed, though not near each other. The charge had jumped from the tree about 6 feet from the ground to the iron roof, and the current had affected all of them in passing.

My elder brother Alex, who was in the Civil Service in Natal, used to make a trip up country with me occasionally, as his health was not good; he had while riding in a steeple chase burst a blood vessel and was never very strong afterwards.

One trip it rained incessantly and all the rivers were in flood. While we were delayed at the Wilge River, three English military officers, who were going on a shooting trip, but had only short leave, 
were much distressed at being obliged to turn back; so I made a raft of some casks and planks, and swam a rope across, and in two or three journeys got them over. They were grateful, but I never saw them again.

Being weary of waiting, Alex. and I decided to ride on and let the wagons follow; we had to swim every river to Pretoria and the wagons did not arrive until three weeks later. Before leaving the wagons I swam over the Wilge River to Mrs. van Reenen's, and bought a fat cow for slaughter for the men, and in getting her over I nearly got drowned, owing to my horse being a bad swimmer and hurting me in the rushing water. He got washed on to an island and I could hardly get him off. The horses we took on at Pretoria were good, and gave me no trouble, but the trip was severe on Alex, who was not used to such exposure and fatigue. I have some sketches he made of places en route; he was a natural artist and a dear, brave, lovable fellow as ever lived. $\mathrm{He}$ was great at private theatricals, and afforded much amusement to the quiet, little English côterie in Pretoria, where we were then like one large family, but nearly all are gone over to the "Majority." Once on our way home at Sea Cow River on New Year's night we came upon a big dancing party. The friendly old Dutchman invited us to join and we made a night of it, dancing with the Boer girls till daylight with intervals for refreshments. That trip seems a hundred years ago, but it is really only about fifty. From 1857 to 1870 I was constantly on the road between Pretoria and Durban during the summer from September to April.

In the early days, when I had to go so much up and down the road to Natal, there were certain inns where one was sure to meet some good fellows, and 
many a pleasant evening have I spent at Nixon's on the Bushman's River, (now Estcourt,) where there were many intelligent English gentlemen farming in the district; a cherry, fine lot of men. Old Dodd's at Sandspruit, under the Berg, was another kindly halting place. I first met Harry Escombe, who afterwards became a prominent politician and a most useful and respected citizen, in a little wayside place near Wilge River which he and Herman Solomons had together.

There were then numbers of young Englishmen farming all about Natal, but of late years they have decreased instead of increasing in numbers. With the increase of the native population, the invasion of Asiatics, the want of unity between the two white races, the expectations of the early, hopeful days, of the Colony have not been fulfilled; and Natal bids fair to become a Native reserve, with all the retail trade in the hands of the Indians, and Durban a forwarding station for the interior commerce. This should be an object lesson for the rest of South Africa, and unless this insidious invasion of Asiatics into the Transvaal is stopped, it will soon be no country for the white man. 


\section{Chapter VII.}

\section{TREKKING TO CAPE COLONY}

In 1857-8 I started with two wagons loaded with tanned game hides, hippo sjamboks, kameel (giraffe) whips, buffalo soles, etc., for the Free State and Cape Colony, to sell for cash, and exchange for sheep. My brother Edward accompanied me, and Lewis Devereux also had one load, and Hendrick Vermuelen one. Devereux's oxen developed "lung sickness," before we reached Kroonstad, and he decided to return to Pretoria, so I took over his load, and rather overweighted my two wagons. Vermuelen and I continued together to Riet River where he got among relations, and I continued on to Murraysburg in the Cape Colony. Here I stayed for 10 days with $\mathrm{Mr}$. Jacob Burgers of "Vlei Plaats," a splendid specimen of the best class of South African farmer. He was shearing sheep and reaping wheat and oats, and I gave him my men to assist him in exchange for his giving me the run of his grass vlei to feed up my oxen, who were dying of hunger, as they would not eat the aromatic Karroo bushes, and the average Colonial Boer gave nothing but the worst veld he had for "outspanning." One day Burgers, Albertus Meiring and I, went to shoot springbok to feed such a lot of working hands, and we shot over 70 in the two days we were out. The bucks were migrating north, and were in hundreds of thousands. In those days the districts of Murraysburg, Middelburg and Hanover were very wealthy, but of late years the farmers are poorer, partly owing to the deterioration of the veld due to over- 
stocking, no fencing, and driving stock every night long distances into kraals, and so resulting in hardening and cutting the surface of the ground ; diminished rainfall and vegetation. I sold much of my stuff in these districts and got together a large troop of sheep, which I sold to butchers. We continued, after leaving Coetye Burger's hospitable home, to the Buffalo River, where an old curmudgeon of an uncle of his lived, also a Burgers, who would not give us any grazing, and a few miles beyond his place a severe hailstorm killed three of my hungry oxen, so I turned homewards via Hanover. Near here we were "outspanned" on a farm, and doing a trade with the owner, when about a dozen Boers returning from a wolf hunt turned up and got off to inspect the leather. Just as they were beginning to buy, their horses with one accord commenced kicking, rolling and behaving madly, then scampered away into the dim distance, and the riders after them. I said to the old Boer who looked stolidly on "What is it?" And he answered "Dit is de bij nest neef" "(it is the bees nest nephew.)" Bees get infuriated with a sweating horse, and a swarm in the wagon house had turned out en masse to sting the unfortunate horses. The old Boer said he did not think that his friends would catch their horses soon, and they didn't. I waited a couple of hours and then trekked. They may have collected them sometime during the week.

I had to buy three oxen to replace the dead ones; one was so savage that he nearly killed one of my boys, and chased me on to the wagon, and poked his horn through the side of the front chest, just missing my "hind" leg. The pious Boer had given him an excellent character, but he had suddenly changed, and became so dangerous, that I shot him for the boys to eat. 
At "Oorlogs Poort" a storm caught us, and as soon as it was over a Hottentot galloped up and drove my oxen off. I saddled up and overtook him and "sjambokked" him properly; he then galloped off to tell his master, but I got there first and explained matters, when I was reprimanded for hammering the Hottentot, but allowed to proceed free. This farm is now "The Willows," owned by a Mr. Hall, Mr. C. Southey’s brother-in-law.

After leaving here we were snowed up for a couple of days close to Compassberg, the highest point in the district, and lost a couple of oxen from cold.

It was a long five month's trek and sometimes rather tiresome, but there was good shooting and plenty of fresh air, and Ted and I enjoyed the novelty of it all. The chief drawback was the drought, and my oxen giving up, as they could not eat the dried up Karroo bushes, being used to grass country.

Near Philippolis the Griquas were most insolent, they had taken the oxen of one Gert Emmenes, and while he was getting them back, one party of them took the wheels off the wagon. I found his poor wife and children sitting disconsolate, not knowing what would happen. The Griquas came bluffing us, but I had my horse saddled, and plied them with rhinoceros hide, and the drunken scoundrels cleared off to fetch more men, but they did not come back. We helped Emmenes, (who soon returned with the oxen,) to lift his wagon on its wheels, and escorted him on the way a bit.

Richard Harvey, who had a large store at Paljasfontein, was buying farms from Adam Kok's people, who were to migrate to Griqualand East, 
now Kokstad near Natal. These Griquas did not deserve to have farms; they were never sober and would sell their coats, as well as their farms, for drink. They will die out as the Bosjesmans and Hottentots have done. They are a drunken, filthy, immoral lot, and will never become really a civilised and useful community. It is well that they squandered their farms.

I did fairly well out of this trip to the Colony, notwithstanding the losses of oxen from drought, but my two companions were less fortunate. Devereux turned back and some of his oxen died, and old Hendrick Vermuelen used to fight with his two Kaffir boys every day until at last, when I parted from him, they could not stand it and ran away. He then hired a Hottentot, who one day, when he was at a Boer house, broke open the wagon chest and stole $£ 370$. The "Totty" was eventually caught, but with law expenses and what the Hottentot had given away, he recovered very little. 


\section{Chapter VIII.}

\section{BIG GAME SHOOTING TRIPS, ADVENTURES WITH LIONS, ETC.}

In those days the High Veld between the Drakensberg and Heidelberg was swarming with game, and in September and October, dense masses of them would trek out of Natal to the Free State; the whole country was full of deep water pools containing fine yellow fish, carp, tench and barbel. These pools were surrounded with tall reeds and rank grass, and lions in great numbers lurked in these covers, for their prey. A Pole named Drodsky, made a business of lion shooting, and always went alone with one Hottentot, following him at a safe distance with a spare gun and ammunition; he was greatly admired by the Boers for his cool courage and is reported to have killed during the years he lived on the Vaal River, some hundreds of lions, and sold the skins and the cubs he sometimes caught.

I have had wagons stampede at night, when oxen saw or smelled lions, and one night when near Cornelius River, I went to see what the dogs were barking at, one brute nearly caught me, but I never suffered real damage through them on the High Veld, partly owing to my knowing the worst places to avoid at night time; besides they had so much game that they were not hungry. These fine water holes and morasses are now nearly all dried up, and one-time rich grass and clover valleys are dry ditches, due to sheep and goats tramping footpaths from one water hole to another, which in flood time they soon cut into deep "dongas." The 
game, although in countless thousands, never cut up the pasturage like sheep do, and many parts of South Africa are becoming barren, as the water instead of being stored as of yore, is run off in these dongas without benefitting the soil.

When not occupied during the winter in going trips to Zoutpansberg and Spelonken, I used to go hunting in the Bush Veld where in those early days, there were large numbers of game, rhinoceros, giraffe, buffalo, kudu, waterbuck, eland, palla, wildebeest, hartebeest, rietbok, quagga, ostrich, besides smaller antelopes such as duiker and steinbok, and birds of all kinds, francolin, partridge, grouse, guineafowl, koorhaan, pauw, wild duck, pigeon, geese, teal, lions, hyenas, leopards, lynxes, wild dogs, jackals, etc. There was grand shooting and plenty of excitement, sometimes with natives, sometimes with lions, etc., and I have enjoyed having yarns with the old Boer hunters who lived in tents and wagons all along the Apies, Pienaars, Plaatte, and Eland rivers, grazing their stock during winter on the succulent buffalo grass. They lived a primitive, but perfectly happy life, shooting what game they required and having plenty of food, bread, dried fruits, pumpkins, potatoes, mealies, besides fresh milk, eggs and butter, and the better sort made their camps very snug.

I never pretended to be a lion hunter and had a wholesome respect for their majesties, but occasionally had their acquaintance forced upon me, and much as I dislike lion and snake stories, I will relate one or two adventures as they occur to me.

While returning from a winter trip in the Bush Veld with two wagons and a troop of loose cattle; 
after trekking for miles through burnt grass, we arrived late at Sluetelfontein, drew the wagons a distance apart, and made a rough bush "kraal " to keep the loose cattle between the spans of oxen. My horse was tied to the hind wheel of my wagon, my brother and a friend slept in the other wagon, the native drivers and leaders on the ground under their wagon. We had heard no lions and it was very dark. About midnight I woke hearing a gurgling noise, got off, with my shot gun loaded with slugs, (as I had been shooting small buck), and saw an animal close to me which I took for a hyena sitting up in the road, gave him the charge of slugs right in his face, he, a large male lion, gave a tremendous roar, fell, and got up again, and got into a patch of dry grass in a gulley, where after some commotion, he was quiet. The cattle were now all on the alert and I ordered the men to stand round them. When quiet was restored, I looked for my horse, he was gone from the wheel, the buffalo "reim" broken, and the gurgling noise was heard again about 30 paces away. I called my driver, Klaas, to make a flambeau of grass on a long stick, and come with my spare gun. We went towards the sound, and two green eyes were looking at us over the side of my dead horse, behind which the lioness was crouching. Klaas lifted the torch, I fired at the eyes, and in a flash the lioness charged me. Klaas bolted with the light, and the other gun, and in diving under the wagon, cut his head open against a bolt. The lioness stopped a few yards from me, so near that I felt the gravel she disturbed rattle against my legs; she then went back again and lay behind the horse. I got Klaas back with a fresh torch, and promised to shoot him if he bolted again. I fired several shots at her, the brute rushing at me and growling, but turning back each time about half way, as fortunately I had not wounded her in the 
darkness; but hit the dead horse close to her nose more than once. Our white companion was in a "mortal funk" and quite demoralised, so I told him to get inside the wagon and draw the blinds! My brother Edward asked permission to come with me, but I did not like to risk it, so would not let him. Finding it impossible to make a good shot in the dark, I decided to wait for daylight, so built a fire about 30 yards from her, and sent the boys to stand round the cattle while Ted and I watched her. As the dawn was breaking, she gained confidence from being so long unmolested and stood up, intending I think, to lift the horse and take him further off. I fired, and broke her shoulders, and she made a terrible commotion; I had just before firing told the boys to inspan, and get to grass and water on the Elands River. They were just about finished inspanning when the loose cattle stampeded, the two spans with the wagons followed, rushing through the trees, smashing both tents of my handsome new wagons, breaking gear and half killing some oxen, one of my hind oxen being rendered useless - a regular smash up all round. I could run in those days, and I did run, to try and stop the stampede, but only succeeded as far as the wagons were concerned, when the oxen got so entangled in the trees, they could go no further. By this time we were far from the dead horse and lions, and were so employed in repairing damages, that we could not go back to skin them, so went to Elands River, where we found the loose cattle. Philip Minnaar's Hottentot going to the stock farm during the day, found the male lion dead in the patch of grass in the hollow, and the lioness with both shoulders broken, lying near the horse. $\mathrm{He}$ shot her and so he got two skins. It was an expensive amusement for me! Once coming back from the Spelonken, I was outspanned east of Stryd- 
poort, when hundreds of armed Kaffirs passed my wagons, as I thought, on the war path, I hailed some, and they said that Sebedilla, their Chief, had ordered them to encircle game and drive them down to the narrow "poort." I inspanned at once and got into the "poort" just in front of the driving game, and shot seven quaggas for the old chief, for which he was grateful; his whole "Impi" had only killed some small buck, as a black rhinoceros had broken the ring of beaters, and let all the game out. I kept one quagga for my boys, as they preferred that meat to any other game. This old Chief was always friendly to me, and was loyal to the Boers, who had once befriended him; his tribe is Matabele. Years afterwards, in the Volksraad, I used my influence to prevent old Sebedilla's Location being cut into farms, and parcelled out to speculative applicants.

One day while riding a smart little roan pony that was not well trained, I had ridden down a fine giraffe and had just put up my gun to shoot him, when the pony looked up, and, terrified at the tall beast towering over him, swerved under the bough of a tree, which caught me full in the "lower chest," it took me part of the way, and with the recoil, shot me back some yards, the pony going on from under me. I fully understood the meaning of a real stomach ache. The boys caught the pony, and I kept him in hard work after that, until he was sensible.

The Elephant's River, after it is joined by the Eland, Moos and the other rivers, is a fine stream. The banks are lined with grand trees, and rich grass, and there are long stretches of water, ideal for boating. It abounds in fish and crocodiles, and when at all in flood is most dangerous to cross at the fords, 
which the crocodiles appear to watch, and although natives, when crossing, go in line, the "croc" will rush and take one occasionally. I have shot many of these loathsome reptiles on the sand banks of this beautiful river, but no matter where you hit them, they generally manage to get into the water to die.

Along the banks of the Zambesi the natives make stockades into the water to protect the women while filling their water jars, but the wily "croc" sometimes waylays them in the reeds, and attacks them from the land side. When watering oxen, care must be taken not to let them go near steep banks and deep water, as a crocodile can pull the largest ox in, by seizing him by the nose, and then drowning him. Many dogs get taken by them in the bush veld rivers. 


\section{CHAPTER IX.}

\section{HUNTING BUFFALO.}

False economy is bad at all times; it is especially so when purchasing a doubtful horse for hunting in the bush veld. On one trip I had only two horses, the one very good, and the other a worthless brute, I had taken it on the word of one of my friends in exchange for one much better. I had sent notice to the chief Mapela to open all the game pits while I was in the veld, but one row near the Mahalaquena River had been left covered, and my best horse and a fine "salted" mare of Philip Minnaar's (who was hunting with me) fell in, were staked and killed. The chief pretended to be very sorry and promised to pay 10 oxen for each horse, but he never did. He was not friendly at the time, and some Boers who were hunting there left the ground, as they feared that the Kaffirs might kill them. Shortly after this a Boer commando attacked Mapela on his mountain, and General Nicolas Smit, (who was afterwards conspicuous at Ingogo and Majuba,) was wounded. This stronghold of Mapela's is a succession of high bluffs facing the Mahalaquena River. It is formed of conglomerates, in places carrying a certain amount of gold. The escarpment is most picturesque. The loss of this horse spoilt my trip, as I always shot from the horse's back when hunting large game; the horse I had left proved a sluggish, clumsy brute, and brought me to grief more than once. A clumsy horse is useless in the bush veld as he only frightens the game, and then cannot catch up to it when started. One day, whilst riding this slug, a wounded buffalo cow got into some thick gwarrie bushes. 
Philip Minnaar shouted to me from the other side that his gun would not go off, so I entered the bush, when the cow came at me full tilt, and I had hardly time to turn my horse. A man, Casper Badenhorst, who was following close behind me, took fright, threw his gun away which struck my horse on his foreleg. The cow then gained on me and scored the horse's haunches, trying to get her horn into his flank to throw him, but I never used spurs to such effective purpose in my life, and at last lifted the slug over a fallen tree stump, against which the wounded cow brought up with a crash. I jumped off and shot her before she could recover herself, but I had a nasty fright. I then had to ride back, for the gun of the coward who nearly stopped my horse at a critical moment, and which nearly cost me my life. He was too frightened to go into the scrub himself, as he thought there were more buffaloes in it. I would not allow him to hunt with me again, and ordered him and his friends, (who had only joined me as they were afraid of Mapela's Kaffirs,) to leave our camp, and they returned home next day. I had more than one narrow escape. We had about 90 buffalo in front of us in heavy sand veld below Matala's and had shot several; I turned back to kill any wounded ones, among others, a very large bull I had, as I thought, hit hard. I found him standing under a tree in the shade; so tying my exhausted horse to a tree, stalked him on foot. I fired and hit him too far forward in the neck, so he charged. I could not reach the horse, so scrambled up the nearest tree, a young one with two stems, and I was hardly out of reach of his tongue, when he began to bellow and butt at the tree, and as the tree was small tried to knock me out. Fortunately, the bleeding from the cut jugular vein partially blinded him, and he pumped away at the wrong stem, going 
back, and charging with his heavy plate, knocking this stem against me several times. He was snorting blood and glaring at me in a terrible rage.

At last he came to the stem I was on, and as it had no branches for foot hold, I could cling on no longer, so, as he was boring at it, I hung on with one hand, and my knees, and held the heavy gun with the other hand, and when the muzzle was behind his crown I pulled the trigger. The charge was not well home, and the re-coil sent me flying out of the tree with two bones in my hand broken, and a scar which I bear to this day. The gun in one direction, I in another ; but the bull, fortunately, dead. I did not feel much afraid at the time, but for several nights I would dream that he had me and wake up in a perspiration of dread. I can see the savage beast now, trying to lick me with his tongue, to get me out of the little tree. Had he not been wounded twice he would have got me out and killed me. He had the finest pair of horns I had ever seen.

I returned to the camp in an awful pickle covered with blood and gave the people a shock. I think a wounded buffalo the most dangerous of all African animals.

To give an idea of the power of a buffalo's tongue, Philip Minnaar had an old Kaffir named Lefuri, whom a buffalo bull had chased into a tree. The tree was too low to allow him to get out of reach and the only perch he had was one branch. The buffalo actually licked away the entire calf from one leg, on which the poor wretch stood, before the bull was shot by his master. I have seen the man with his shrivelled leg. He went a trip with us, large game shooting about 1862, down the Mahalaquena River. The buffalo's tongue is like a coarse file and of great power, evidently for the 
purpose of grasping the rough herbage on which the animal feeds.

Philip Minnaar, sometimes my hunting companion, was one of the coolest, pluckiest men I ever met-a splendid fellow. One day he saved my life. I had hit a buffalo cow and he could not see where she hid until we saw her standing on an open place, behind a burnt tree stump. We left our horses and went towards her, when she charged me. Minnaar called out "don't fire until I have loaded," but she came on so fast that I aimed stupidly at her forehead, the ball glanced off her horn and never made her halt. Minnaar rammed his charge home, ran sideways towards her and shot her behind the shoulder, and she rolled over at my feet. There was no tree near, and nothing could have saved me had he failed to kill her. Now that I am over seventy and stiff, I can hardly believe that I could jump into the saddle with my gun in my hand, without stirrups, and load and shoot at full gallop; and ride from Durban to Pretoria and back two or three or more times a year.

I was returning from Waterberg Warm Baths and rested the horses over Sunday at Willem Boshof's on the lower Apies River. After prayers (it was Sunday), two young Boers and I went for a swim in a deep pool near the house. They assured me that there was no danger of crocodiles, as the pool was a distance from the river. I undressed several yards distance from where they got in, and just as I was diving I saw an animal plunge into the water not far from me. I scrambled out at once, convinced it was a "croc," but the two youths, although they got out when I shouted to them, said I had only seen a large iguana, of which there were plenty. During that week a Kaffir 
woman, stooping to get water, was killed by my friend the crocodile at the spot where I escaped. Of all dangerous creatures I dread sharks and crocodiles most; one is so helpless when in their native element; on terra firma one can always make some kind of defence. In the early Pretoria days I had built a brick walled house and rode to Magaliesburg to hire Gabriel Ezel, a noted thatcher, to thatch it for me. I was riding a grand grey horse in fresh condition. In the valley west of Daspoort (where the cement factory now stands) I saw a small herd of quagga grazing on the short green veld, and I determined to drive them into Pretoria on my return. In the afternoon, on my way home, I found them still in the valley and gave chase. They were very fat, so I soon came up to them, but they would not cross the "nek" in the range towards the village, so I killed two with my hunting knife, riding alongside them stabbing them in the lumbar (above the kidneys), which brought them down. The second one, a big stallion, kicked my horse on the mouth and made him swerve, just as I was leaning over to stab him. I drove the knife clean through my foot and into the sole of my boot, but I did not feel it much at the time in the excitement, and killed the quagga. I then covered them to prevent the "Aasvogels" (vultures) eating them, and rode to town, and sent Hendrick Vermeulen with his wagon to fetch them, as I wanted the meat for my boys. My toot swelled, so that my riding boot had to be cut open to get it off, and it was very painful and bled a good deal, but I was healthy and it soon healed.

I was told of a strange adventure that befel a friend at the Moord Drift (where the Potgieter family where all murdered by the Macapan tribe). My friend, Robert Lys, was travelling to Zoutpansberg 
and had a Mr. Bell with him, a tall young fellow, just out from England. Bell went down the reedy banks with a shot gun after snipe and had a little spaniel with him. Suddenly a white rhinoceros rushed out of the reeds after the dog. Bell fired, but the shot would not even tickle him. The dog made for the wagon, ran under it, the half blind rhinoceros followed, ran against the wagon, and got his horn into the "aftertrap" full of pots and kettles, with which he made off, taking it some distance, scattering these utensils about the veld to the astonishment and delight of the native boys. Had it been a black, instead of a silly old white rhinoceros, it would have been a different joke, as the blacks are savage and active.

While hunting on the flats below Matala's Mountain, I hired some of his men to carry skins and meat, horns, etc., to the camp for me, the price to be paid was eight head of either quagga, wildebeest (brindled gnu), or hartebeest, for a fortnight's work. I found a troop of wildebeest, killed five, and wounded one badly while running him down in the dust made by the herd; my horse went into a hole and rolled over on to me. The stock of the gun broke, it went off, the bullet passing through the rim of my hat; I was stunned and my shoulder and hand hurt, and when the Kaffirs came up to me I was still dazed and did not know where I was. This was the only time I remember losing my way in the bush veld. The horse's jaw was out of joint and I did not know what to do, but a Boer at the camp knocked it back into the socket with his leather bandolier full of bullets, certainly a primitive, but effectual treatment which would have astonished a "vet."

There is some grand and wild scenery in Matala's and Mapela's countries, and a splendid hunting 
ground then. Now, nearly half a century later, there is little or no game, and the Kaffirs have cut down and burnt square miles of trees. We kept our horses in good fettle on cut buffalo grass and "sorghum" (Kaffir corn), although riding daily after game. One never goes faster than at a walk, or amble, except when actually chasing game, as you would frighten all game away, besides losing touch with your carriers.

I had one grand little cream coloured horse, only 14.2, but I could shoot any game from his back at full gallop. I have ridden him from Pretoria to Durban and back many a time, eight days each way, sometimes swimming several swollen rivers. One afternoon I shot two giraffes off his back and the next day rode from below the "Slagtboom" on Elands River to Pretoria, seventy miles, as a messenger had been sent to tell me that my father was seriously ill. When sometime afterwards I was leaving the Transvaal my neighbour, Nicolas Prinsloo, living on what is now my farm, "Lynwood," gave me fourteen large black trek oxen for him. I knew that he would be well treated, as the better class Boers value a good horse highly and treat them well.

In the dry frosty air of the Bush Veld in winter, I used for weeks at a time; to sleep mostly under the wagon on the ground, and never was in better health or spirits. I preferred it also when in lion veld, as I was better able to protect the horses and oxen. What I did not like was snakes, but they seldom troubled me. One got under my mattress one night for warmth, and the boy killed him in the morning when he took up my bed.

One night, after I had been running about the bush in the dark to turn the horses (which a stray lion had stampeded,) I got to bed at midnight. After 
a time I woke with a start, feeling something biting my toe, and jumping up, banged my head violently on the bottom of the wagon, then saw instead of a snake, a wretched little mouse run out from under my blankets. "Oh, ridiculus mus!"

Once after hunting Buffalo all day on the Klein Mahalaquena River on foot, having left our horses at the camp near "Roodekrantz" for fear of tsetse fly ("Glossina Morsitans"), we, were following up wounded buffalo, our bearers having remained behind skinning and cutting up those killed, and not turning up, we went back to look for them, and found them roosting in trees all round, two "Magali" (black rhinoceros) having charged them. They came off their perches when they saw us. The "rhinos" had left and we could not find them. That night a party of Boers from Bronkhorst Spruit asked our permission to join our bivouac. The fear of the black "rhino" was in both them, and the Kaffirs, and we had an amusing night. After a supper of buffalo grill, without salt, and dry biscuit, we selected trees to get into, in case the rhinos came and charged the camp. I selected a liquorice tree, "Witgatboom" with a comfortable seat in a fork, six feet from the ground; and placed my two guns against it and lay alongside. At midnight a great commotion was started, the Makalaka Kaffirs we had hired to carry hides to the distant wagons, had much overeaten themselves and lay about, when an old male lion jumped in among them, they shouting "Magali," (black rhinoceros), came helter skelter over our camp, mixed up with their overgorged dogs, and blundered over the Boers sleeping by the fires twenty yards away. I jumped into my special tree, but one Badenhorst was just getting on to my seat in the tree, when my hunting cap of strong leather, with my head inside it, struck 
him with full force below the belt and knocked him out; he fell some fifteen feet into a dry ditch full of grass, giving vent to piteous howls in his funk. The other Boers came tearing over our fire, one putting his foot into an antbear hole, shot after Badenhorst into the donga. Then our old Hottentot hunter cried out that it was "only a lion" so I got down from my tree and being then quite awake, went with the Hottentot to where we heard the lion purring in the bush, having helped himself to meat. I shot him, but he was a poor old brute with broken teeth, so we all turned in again in the cold. On the way back to camp next morning, my Scotch staghound, who had been unwell for some days, started barking at a buffalo cow I had wounded and lost the day before. She charged out of some gwarrie bushes where she had been hiding and came after the dog straight before me. I jumped behind a tree and she now "spotted" one of the Bronkhorst lot bolting up an open glade, and gave chase. She had to pass close to me and I gave her an eight to the pound bullet behind the shoulder and dropped her, but poor Bronkhorst kept on sprinting in his unbleached calico breeches, a sight for sportsmen; and the harder I shouted to him to stop, the harder he ran, as he thought the cow was still after him. He got such a fright that he decided that it was no place for a simple minded agriculturist in linen trousers, and as they were short of ammunition, and had no horses, they returned home with what meat we gave them.

I am now ashamed to confess that in two days we shot twenty-two buffalo to three guns, but I was young and thoughtless then and was carried away with excitement. For my own eating I had mostly birds, preferring them to venison, and one had such 2 varied choice. 
I had ridden hard from Pretoria to Rustenberg on important business, and having finished it returned the same night, when a few miles from Pretoria, the sun being up and getting warm, I fell asleep on the horse, when all at once I found myself sitting on the road, and President Pretorius and two others sitting on their horses laughing at me, my horse having shied when they came up. I have always felt kindly towards the old ex-President (who died in poverty), and for good old Hendrick and his kindly wife.

Cornelius Botha, who was afterwards Paul Kruger's private secretary, and old Piet Venter, had a terrible experience. They were travelling in a cart from Pretoria to the Warm Baths, it was getting late near "Vaalboschfontein," so they could not get over the Springbuck Flats in daylight. Suddenly a lion sprang on to their horses and killed them both, and then more lions joined in, eating them while in the harness. The two men crouched in the bottom of the cart, which was open and at an angle, with the pole on the ground, and every time they moved in the least the lions would get up and growl. This kept on through the night. At daylight, when the lions had finished the horses, they went off. Why they did not kill the two men, (which they could easily have done,) is not to be explained. Botha said that the night seemed to interminable, and they had to walk twenty-five miles after their awful night's vigil. "Vaalbosch" has now some cottages I put up for a winter shooting box, Kaffir kraals, and the railway to Pietersburg passing through it, and there are houses and stores along the road. Then there was a stretch of forty odd miles without a habitation as I have reason to remember.

On the return from Zoutpansberg one trip I was sitting with P. Minnaar on his wagon, two of mine 
following, when we saw a lion stalking my one span of oxen. I jumped off, my boy hastily handing me my rifle, I bowled him over, but he was not dead and the noise he made started the oxen on the stampede again, and gave us trouble, so I did not get him. This was in broad daylight, so he must have been very hungry.

Another time I was walking up a bushy hollow looking for reitbok. I was stalking one when Ben Holder, my Welsh wagon driver, cracked his whip towards me which annoyed me, as I lost my buck. He kept on shouting and came running towards me with a rifle and pointing behind me. I looked, and there was a huge, black-maned lion standing behind the stem of a tree and looking round the side at me. He did not expose more than half his ugly face, so, fearing he would bolt when he saw Holder coming, I aimed at his eye but struck the tree in front of him, sending the bark into his face, and the way he bolted, all confused, was too funny. Holder said that the brute had been stalking me for a mile, and that was why he shouted, and at last came up to me as I would not take heed of him. The Blood River from the "Lun's Klip" to old Venter's was always a bad stretch for lions. 


\section{Chapter X.}

\section{AN UNLUCKY TRIP.}

One evening, when outspanned at "Rust de Winter," on Eland's River, my Kaffir boy came running to tell me that a big snake had caught a pallah (rooibok). I took my gun and found a python with the horns of big ram sticking out of his mouth. I shot him, and the boys staked the python's tail to the ground and pulled the buck out. He had not been long killed, but they would not eat the buck as they said it was unlucky, that I should not have shot the snake, but have let them peg him to the ground while dormant, and they foretold trouble on our trip.

Two nights after that, I was dining with old Mr. Kort Joachim Prinsloo, who was encamped close to the "Gift Spruit" below " Kameel Poort." After dinner the old man said I had better go over the spruit to my wagon before it got too late, as the lions had been killing several cattle lately. I went, while my oxen were still grazing, and when I got up the bank I saw an animal walking up the spruit in the sand. I whistled, and my two splendid dogs came and started barking as soon as they saw, what I then recognised as a lioness, as she ran into some reeds. I cleared the spruit and reached the wagon in less than no time, and started tying up the oxen before they should smell the lions and stampede, when finished, I wanted to go to help the dogs, who were still barking near the reeds, but the boys begged me not to go from the wagon as there would be more lions than one. We made fires and at last 
when the moon rose, went to bed, the two boys sleeping close to the wagon with a big fire beyond them. I slept in the wagon but with the front flap open and my loaded gun on the bed. About one o'clock, (the moon shining brightly) I was awakened by a yell. I jumped out half asleep, nearly on to a lion who was standing over a kaffir boy. The lion got as big a fright as I did, and dropped the boy, bounding into the bush, but not before my old Jonas had struck him over the head with a fire stick. I saw the sparks and hot coals on his mane, took aim at him as he bounded away, but found he was just in line with Mr. Prinsloo's camp, so I jumped to get a side shot, but he was too quick for me and I never got a shot at all. The boy, September, had been seized with his kaross round him which probably saved his life, but his arm was broken in two places while three of his ribs were also broken. The wonderful part of the performance was, that the lion had torn to pieces, a new, white blanket I had given the boy and only seized him when he came to the familiar skin kaross. I had to sit up the rest of the night with the wounded boy who was badly lacerated and in agony. Next morning old Mrs. Prinsloo gave me remedies, and we bandaged him as well as we could. He said that he wanted to get to his kraal in Rhenosterpoort. At great inconvenience I had to make him up a bed in the back of the wagon by day, and let him sleep under the wagon at night. I got him to his people and they said that they would cure him, although the bites were festering badly. I paid him something extra besides his wages and got a friend of his in his place. I never heard of him again. Old Jonas declared it was all because of my shooting the big snake. We certainly had a harassing trip anyhow. 
We were outspanned for the night at "Crokodil Heuvel" on the Olifant River, when about 30 of Sekukuni's Kaffirs, who were then not on friendly terms with the Boers, came to the wagon and asked what I had on it. I told them to mind their own business, but the wounded Kaffir (who was jumpy), told them that I had a load of powder and lead for the year's elephant hunt. They immediately demanded some, and got so impudent that I took my rifle and told them that I would shoot anyone coming within a hundred yards. One fellow, I think their head man, would not go, but threatened to kill me, so I lashed him with the long wagon whip and when he saw that I meant business, he followed the others to a stony kopje a few hundred yards off, where they built large fires, blew on their war horns, and shouted threats till nearly morning; but as it was moonlight, did not venture near the wagon. At daylight they crossed the river and I did not see them again, although I expected that they would waylay me in ambush ahead, so kept a keen look out. We got to the Ingumpi River, near Sebidella's location that night, where we were safe, as these Matabele were friendly. Old Jonas, who had relations in the kraals, told his tales to them, and they all agreed that our troubles were the result of my shooting the python with the rooibok in his mouth. I wanted to leave the wounded man here but he would not hear of it, as he was of another tribe, so I had to cart him on in my only wagon. I determined never to travel in the bush veld again with only one wagon.

While passing through some thick bush, when just leaving Olifant River, some wild pigs frightened the oxen, and they ran the wagon against a tree stem, and cracked the axle which was of assegai 
wood. There were no iron axles in use then, so I had to pile the whole load in front and could only travel slowly until I got to Venter's, near Rhenosterpoort, where I had a new one made. Some nights after this accident we could only get as far as the heights above "Deelkraal," near what is now "Eersteling," when it got late, so I had to outspan without water, to allow the oxen a little time for grazing before being tied up, as it was notoriously bad lion veld. Before it was dark, the brutes began to roar on all sides, and the wounded Kaffir was jibbering from fear. Before the moon rose, I fancied the oxen were restless and as I was sitting on the chest in front of the wagon putting my "veldschoens" on, when right in front of me, a lion made a spring at one of the after oxen, which was tied to the "dissel-boom." It was dark and he missed the ox, so before he could recover, I put a shot into him. The blood next morning showed that he was badly hurt. He drew off into some old stone kraals and lay growling, but did not come again, though two lionesses kept me going all night. I lit a strong lantern, and put it on top of the wagon, when they kept chasing my dogs to within the radius of the light. I fired at their dim forms several times; I think I hit one once, by her growling in rage, and next morning found the blood spoor but could not find either of the wounded ones, though I prevented them from taking any of the oxen, which were tied up to the wheels with two buffalo "reims" each. Next morning the oxen overtired as they were, wanted to stampede, whenever a bird flew out of the grass. When oxen get panicky for lions, they are dangerous. I was much relieved when I got rid of the wounded boy at Rhenosterpoort, and got a less frightened one to help me on to Zoutpansberg and Albasini's in the Speloken, which was my destination. 


\section{CHAPTER XI.}

\section{GIRAFFES AND MORE LIONS.}

One trip, on my way to the Spelonken, the wagons had just crossed the Doorn River to outspan when I spied three giraffes walking away from the river. I ran after them on foot and wounded one, when I happened to turn round and saw a large black maned lion bounding out of the river towards me. I had no time to reload my 8 to the lb. muzzleloader, so jumped behind a large antheap with bushes growing out of it. $\mathrm{He}$ came on, but kept looking over his shoulder-the echo of my shot must have wakened him out of his evening nap-I turned round so as to keep the bushy antheap between us; when he bounded past only a few yards off. When some distance past, he looked back and saw me, and I thought he was going to stop, so in my fright I jumped on to the antheap, waved my hat and shouted loudly, when to my intense relief he continued his course. When a lion starts bolting he seems like a human being and becomes demoralized. With those old muzzle-loaders I wonder we were not all killed by one animal or another. If I had had a breech loader I could have killed him as he passed close to me. When you did hit, it was, however, a different thing to the 303 used now, you generally got him, but your shoulder was often blue and green from the kick. We used to pad the stock of the 4, to the lb. and 8 to the lb. rifles (spherical bullets). Afterwards, conical bullets came into use, and the smaller bore was much handier for using on horseback. It is wonderful what splendid shooting the old "voortrekkers" made with their smooth bore old fashioned flintlocks. 
When I first went to the Transvaal many Boers had nothing else. Once I was watching a lot of Massalarooms kaffirs fording the Olifant River near Commando Drift, when the river was rather strong and the water up to their waists. They were following Indian file, holding each other's hands for fear of crocodiles, when a big one came lashing down stream, seized a kaffir in the middle of the string; carried him down stream before the poor creature fully realised what had happened. The others burried out to the bank but could do nothing-Kaffir and "croc" had both disappeared. I never bathed in those bush veld rivers, which also contain poisonous fish. I caught one about nine inches long and in taking him off the hook, a spike he had in his front fin ran through my hand, which festered so badly that I feared I would lose it.

Kaffirs have a queer idea of justice. At the lower drift of Elands River near "Israel's Nek" I bad just shot a waterbuck when some of Sebidella's kaffirs came up with a boy of about 18 tied up with bark cords. They asked me for some meat, and I made them skin the buck and then gave them some. While grilling it, some of them got a large stone, and were going to tie it to the boy's neck to throw him into the river to drown. I told them I would not allow it, but they said they must drown him so that Sekukuni's people, to whom he belonged, should not find him, that the Sekukunis had killed one of their friends while hunting, so this boy was the first instalment of their revenge. I gave them most of the buck's meat but took the boy from them and when they tried to get him, I threatened to shoot the first who touched him. They were of a friendly tribe and did not care to go to extremes with a white man, so I mounted guard until the wagon 
came near, then I took the trembling wretch with me. Two days later I met some of his tribe and handed him over to them. He told us that he had wandered from a hunting party shortly before I met him. The gang who were going to drown him had just caught him and brought him to the river. My kaffirs said that he was only a "Bapedi" and very thin and not worth troubling about, and I might have let the Matabeli drown him. The fellow himself seemed rather indifferent about it; he had been well fed at the wagons and preferred to go on with us but I did not want him, so he returned to the bosom of his family.

All my spare working oxen and cattle I sent to fatten in the bush-veld in winter. One year Philip Bronkhorst had them at Rooibokfontein under the Swart Rand near the junction of the Eland and Olifant rivers. On my way to Zoutpansberg I called to get some fresh spans and found my cheery old friend, Willem Hans Prinsloo and his son Adrian, and one or two others there. I asked if there was much game as it looked an ideal bit of country. Old Willem, nick-named "Boschbok" said that there was game, but as an "Englishman could'nt shoot, what did it help." $\mathrm{He}$, however, sent Adrian with me to see that I did not get lost in the hills. We soon saw a blaauw wildebeest (Brindled Gnu), which stood gazing at us about four hundred yards away. I aimed at him, but Adrian said "Don't shoot, he is too far ;" as he stood still, I dropped him with a bullet between the eyes. I had then a Pryse and Redman rifle, conical ball, and Adrian was astonished at its accuracy. A little further we came on a herd of pallah and I shot two, with only one shot each. We then left the boys to skin the game and bring the meat into camp. When we arrived, old "Bosch- 
bok" said, "Well Adrian, how often did the Englishman miss?" Then old Willem and his friends had a good laugh at my expense, but when sometime later the boys brought in the game and he heard the truth, he seemed quite disappointed, but quite good natured over it. He was a fine old sportsman himself. While we were having supper in Bronkhorst's tent about 9 a.m., we heard a bellowing of cattle and a crashing of the bushes which formed the kraal. Then a general stampede of all the cattle in the big kraal (about 500 of Bronkhorst's and mine together), and the silly creatures bolted in a mass. There was a lull, then we heard another cow bellow, then another stampede, then another bellow, further and further away. At daylight next morning we found one cow dead in the kraal, and eleven of poor Bronkhorst's cows and heifers lying dead at short distances apart, also a large front ox of mine. The lion had eaten the breast of the $\mathrm{x}$ and the udder of the cow and then walked off. Next evening old Willem put up a gun trap with an old smoothbore loaded with slugs, tying a tempting heifer (one of those the lion had killed), in front of it. About the same time, while at supper, we heard a loud report, a sort of roar and gurgle and then quiet. One fellow, who was a notorious coward, proposed we should go in the dark and see if the lion was dead. We asked him to lead the way but he had several reasons for not doing so. Next morning, we found a big maned lion dead, with one slug hole just over the eye. I gave the head to John Robert Lys, who had it over the door of his office in Pretoria for years. This little episode made our cattle skittish, and Bronkhorst told me on my return that they had stampeded once or twice since. On my return, Philip Minnaar and his wife accompanied me from 
Rhenosterpoort, and we stayed a couple of days at Bronkhorst's (who was his brother-in-law). I took a couple of spans of fresh oxen, leaving my tired oxen, and he asked me to lend him a span for a couple of treks to rest his. I lent him a fat red span I bought from Jacobus Rademeyer and these had been in the lion kraal. We had not gone more than two miles, when some guinea fowl startled them; they stampeded with the wagon and frightened poor Mrs. Minnaar dreadfully. The brutes rushed the wagon against stumps of trees until both hind wheels were shaken to pieces and the tent broken. When we got them they were entangled in trees, so we had "to outspan," send the oxen back, get tools and assistance to mend the wagon; poor Philip regretted not having stuck to his tired oxen. Tinkering up his wagon, and with the help of the inevitable raw hide reims, we reached Pretoria safely with our loads of ivory. There was never any monotony on these winter trips through the veld; something was always happening; it was charming, notwithstanding some hardships now and then. I never stayed longer in Pretoria than just to arrange business matters, and prepare again to go either to Natal or Zoutpansberg; the village life soon tired me.

Where the road leaves Elands River to go over the bush ridges to the Olifant, on the top of "Israel's Nek" is a huge mound of small stones which the Kaffirs say has taken ages to build; each traveller as he passes adds one stone to make his journey safe and prosperous. You see these mounds on many hill passes all over the country. When I first knew this part there were troops of Koodoo, Giraffe, Eland, Rhinoceros, Brindled Gnu, Quagga, Hartebeest, Waterbuck, Rietbuck and vast herds of 
Pallah, Rooibok, quantities of Ostriches, Pauw, Knorrhahn, Bustards, Guinea Fowl, Francolin, Red Wing Partridges, Grouse, Spurwing Geese, Widgeon, Teal and Ducks; a game paradise. Now nearly all are gone, and the whole beautiful country destroyed by Kaffir kraals, the trees chopped down, " the place thereof shall know it no more." The Olifant River is a beautiful stream, the banks lined by large trees and long stretches of water fit for boating. I have spent many a happy day hunting on both banks, mostly quite alone, sometimes with a companion, once with my dear brother Alex, keen sportsman and delightful companion. 


\section{Chapter XII.}

\section{AN UNPLEASANT RIDE.}

Messrs. Evans \& Churchill of Natal had branch stores in Pretoria and Zoutpansberg, and I accompanied Mr. Evans on a trip to the latter place. At Krantz Kop, beyond Waterberg, we came on a farm where the people were all on the "spree," and when I introduced Mr. Evans, who was a particularly natty, well-dressed man, one awful looking "takhaar" with fiery red beard tried to kiss him, and I nearly got into a row rescuing him. I shall never forget his look of despair and horror when he said "Struben you can never allow this;" poor man, it gave him a fright and he didn't forget it! He was an amateur geologist, and when we were outspanned at Lun's Klip, he showed me what he said was gold bearing strata. Years afterwards the Eersteling goldfields were discovered near here. I did a lot of work for Messrs. Evans \& Churchill. They were the best class of British merchants; both educated, intelligent gentlemen, I showed Mr. Evans the wild cotton in Zoutpansberg, out of which the natives in the early days made coarse rugs, bags, etc., and I often tried to get someone to experiment in the Spelonken in growing cotton, coffee, tea, tobacco, etc., but I had neither time nor money to do it myself - " a miss is as good as a mile."

One trip I did for Evans \& Churchill nearly prevented me writing this journal for you children. They had a business connection at Rhenosterpoort run by an old Scotchman named Watt, who had married a Boer girl, and been settled in the country 
for years. I think he was a deserter from the troops in Cape Colony. $\mathrm{He}$ had almost forgotten what English he ever knew, and never properly learned Dutch; the mixed jargon was awful. This genius came to Pretoria to get $£ 850$ in cash to pay for a lot of ivcry he had bought; but he got on his usual "drunk" in Pretoria, so that he could not be trusted with the money. I was asked if I would take him and the money back to Rhenosterpoort, as they (Evans \& Churchill) did not wish to lose the ivory. I little knew what I was undertaking, and after much trouble in getting Watt away from the drink, started with him, each of us with two riding horses. A few miles beyond Wonderboom he fell off, and insisted on lying on the ground, and I fairly kicked him on to his horse; we slept at Daniel Kruger's on Apies River. Next morning he said he was ill and told the Boers that I would kill him on the road and take all the money. It was late before I got him under way. I had the money sewn in a strong canvas belt, slung across my shoulders, and no one can imagine what agony it became to ride 50 or 60 miles a day with $£ 800$ in gold and $£ 50$ in silver strapped as dead weight on you. If I had tied it on to the saddle, the belt would soon have burst. Watt was unarmed, or when drunk, might have shot me. I had a heavy rifle (there were no revolvers then), and this, much against the advice of old Kruger, I left with him, as I could not manage the money, two horses and a heavy gun; old Kruger said goodbye, but never expected to see me back alive, riding unarmed to Zoutpansberg in those days. After Kruger's, there were no houses on the road, until we reached Waterberg, 60 miles from Pretoria. We reached Pienaar's River in the afternoon, and while I was watering the horses, I saw the old scoundrel Watt, slyly take a bottle of brandy out of 
his great-coat pocket and have a drink. I watched my opportunity, seized the bottle, and threw it into the river, when he got into an ungovernable rage, rushed at me, and in self defence I had to give him a thorough pounding. It was getting late, so I saddled my horse and told him to saddle his, but he would not, so I told him I would thrash him again if he did not. He said he would die, now that he had no brandy to keep him up; I started however, and he followed. He had had this brandy hidden all the time; which accounted for his keeping his "drunk" up so long.

As we neared "Vaalboschfontein," I saw no less than thirteen lions standing on the road; so I made a wide detour to avoid them. They watched us all the time, but they did not follow us. This sobered Watt a little, and he came closer to me, as it was getting dusk, and we had still about 25 miles to ride to get to Groot Christiaan de Beer's, at Waterberg. We kept on steadily. I had two splendid horses and Watt's were fairly good, but it got dark long before we reached Sandfontein (where Johaan Rissik's farm is now). From there we went through heavy sand, and thick trees, and it was as dark as pitch. When about two miles from $\mathrm{D}_{0}$ Beers, my horses suddenly bolted, and nearly threw me, old Watt's horses followed; but we could see nothing, though the horses had seen or smelt lions. When we reached the farm, Bernardus Enslin (who was afterwards shot on Selikat's Nek by Philip Minnaar in the Boer Civil War) on my knocking at his door came out, and when I told him where we had come from, he said we were lucky to have escaped as some lions had caught his bull that evening on the sand ridge, just where our horses had shied in the dark. I fed the horses well on 
good forage, and old Watt fell asleep (quite done up) under a tree at the back of the house. I left him, as he was useless anyway, and I told Enslin not to let him get liquor. Next morning we started early and reached "Naboomfontein" at sundown. We could not go nearer the Macapan's Poort; the kaffirs were troublesome, as some had been shot shortly before. I made a rough screen of such thorn bushes as I could collect (having no axe), and collected a lot of fire wood, as it was a bad place for lions. I tied up the horses and had a scratch. supper. Watt said he was ill and would do nothing but sleep off the effects of his long "drunk." As soon as it was dark the lions commenced roaring along the river banks, and towards midnight came so near that I could hear them moving about and breathing in their peculiar way. The horses were tired, securely tied with strong reims, behind the thorn fence. I stood behind it and talked to them; but the lions did their best to make them break away. I kept the fire going, but had not much wood and I was so dead tired that I dared not sit down, or I should have fallen asleep. Before daylight the brutes went off after other game. The moon was then up, I knew that I could not keep awake much longer, so I wakened up Watt and made him saddle up; we started along the road at a good pace, for two reasons; first to get a distance from the lions, and secondly to try to get through Macapan's Poort before any kaffirs were about. I was going gaily, when I found myself in the middle of a group of buffaloes, which had been lying on a bare place near Kotjes Zijn Loop. In a minute they were galloping all round me, but soon gave my horses a wide berth, my only fear then was that in the dust they made, they would not see me, and run me down; my horses behaved well, and stood still, till 
all were past. Old Watt who was some distance behind, escaped this extra little excitement.

We rode on fast and got through the Moord Drift but we met no kaffirs, though they must have seen us from a distance, as they commenced blowing their war horns in the hills. We came to a deep rivulet with green grass on the banks; I off saddled our poor horses in the bottom of the gully where they had a good feed and water; and we a bad breakfast; then on again to a small stream on Blood River highveld, where we again off saddled, and I lay down to rest, Watt being already asleep, as usual, the log! Fancying that I heard my horses snort, I jumped up, saw both my horses with their heads up, watching something, and I noticed some vultures on a small tree. I went to turn the horses, when I saw two lion cubs lying under the tree in a small hollow, and following the horses gaze, saw to my horror a lioness, a few hundred yards up the gulley, watching her cubs, and also the horses. I had no choice but to walk away from the cubs and get between the lioness and the horses, as, if she killed them, I was a "gone coon" anyway. I got in front of the horses, turning them slowly towards the saddles, and I think the cubs saved me, as the lioness looked less savage when I went away from them, but the fright stopped a year's growth. No wonder I am white haired after all the scares I have had! I " up saddled " at once, old Watt's two horses were showing signs of fatigue, and we had to ride all down the Blood River in the dark, through a country full of lions, all the way to old Piet Venter's, where we arrived about midnight. I was about done up and slept till late next morning. Old Venter was astonished that we got through alive; the next day I deposited the old wretch Watt at 
Rhenosterpoort and handed over the confounded money that had made sores on my shoulders and ribs; filthy lucre with a vengeance! I had told Bernardus Enslin and the De Beers about the thirteen lions at Vaalbosch, they and the Swanepools traced them to a vlei on the Platte River, and shot nearly all of them. If I had been alone with my two splendid horses, I should have been much safer, as I could time myself, but hampered by a useless, sodden fool, it was the most dreadful ride I ever experienced. After doing the business entrusted to me, and resting my horses two days, I started back home. To my intense relief $I$ heard that armed Boers and a small convoy of about fifteen wagons were ahead of me, going to Magaliesberg, so I rode on and caught them up a few miles beyond (where the lioness nearly took my horses on the way up). The good natured old pioneers were most kind; I stayed with them until through Macapan's Poort, and past Waterberg, when I rode on to old Daniel Kruger's, who, when he gave me back my clumsy gun said that he and his old wife (who was a great medicine woman in the district), had said that they would never see me alive again. Looking back, I think it was more luck than good management; going those hundreds of miles through bush country, swarming with wild animals and savages, without firearms. I never, till then, realised how nearly a man can break down, if the strain is kept up too long, All the ivory in Africa was dear at the price. 


\section{CHAPTER XIII.}

\section{BUSH-VELD AND OTHER TREKS AND ADVENTURES.}

My first shooting trip to the bush-veld was with Hendrick Vermeulen. He laughed at me for shooting the guinea fowl and francolin on the wing, and said he would show me how to shoot! Near a spring at "Varkfontein," where birds came to drink in the evening, he laid a long line of mealies in the open, then hid with his old long flint-lock gun behind a bush, and when the poor guinea fowl were in a dense row he fired and shot, to my horror but to his great satisfaction, no less than fourteen in one discharge. His old flint-lock caused me much amusement, as it frequently missed fire after he had stalked game with infinite trouble, then he would fairly dance with rage, and rub the flint and pan on the rim of his hat to brighten them up.

On one of the early September trips in Natal we were outspanned in green grass across the Vaal river on a Sunday and game came temptingly near to the wagons, but I made a rule not to shoot on Sunday, the day of rest. Dolf Jansen, my Boer wagon driver and conductor, could not withstand the temptation, so he crawled up a donga to stalk wildebeest. I watched him through my glasses and every time he aimed at one, I heliographed with a looking-glass on to the wildebeest, which jumped away. At last Jansen came back and said now he believed that it was wicked to shoot on Sunday, because although he was certain that the wildebeest could not see him, every time he was about to 
shoot it suddenly swung round and galloped off. I instructed the boys not to tell him about the lookingglass, and next day when I shot more game than he did, he was convinced it was because he tried to shoot on Sunday. Poor old Dolf, he and his plump old wife Tanta Jacoba are dead and gone long ago with so many more.

In the winter of $1863-4$, Alex. and I went for a short shooting trip to the near "bush-veld." One afternoon, near Dronkfontein, we espied two giraffe bulls. As he was keen to get one, I told him to get alongside and shoot one, and kept close behind him on my old Buckley. His horse Punch, was game enough, but he could not make him go near the giraffe, so he called to me to try and get up. I at once did so and shot one from the horse's back. $\mathrm{He}$ was eighteen feet to the top of his head. Then afterwards I shot another, as Punch still would not let Alex. get near. This giraffe lay apparently dead, and I was packing bushes on to him to keep "aasvogels" off, when Alex. shouted to me, and turning round I saw the giraffe standing right over me. He had sufficiently recovered from the shot to get up, so I shot him under the chin, bringing him down like a felled tree (poor brute), nearly on top of me. He was 18 feet 9 inches in height. We skinned one, and went on later to "Dronkfontein," where we found the Oppermans and Cornelius Erasmus, to whom I gave the two giraffes, as they had not shot any, and Erasmus afterwards gave me some whips made of the hide. They started at dawn to fetch the animals; I gave them a boy to show where they lay. Alex. used to enjoy sitting round the fire listening to these old Boer hunters' yarns, which they have a very graphic way of telling. Some of these old Boers were most friendly to me always. 
At Pienaars River some wagons of mine left us, and went on to Zoutpansberg and my dogs followed them, which we did not notice for some time. We could not be in the bush without a dog to warn us of the lions at night; so after much persuasion I got old George Scheepers, (nicknamed "Proppe" from having a plug in his nose), to lend us one for the trip. Old George was full of praise of the great ugly grey brute, said he would never forgive me if I lost him. We had some fun out of him; he had a good appetite, but was the most arrant coward possible. When the hyenas came about the wagon at night, he crouched among the kaffirs, whining with fear. One afternoon I shot a giraffe and the boys were skinning it, the dog was smelling around, when a kaffir stuck a knife into the immense paunch (distended with gas); the explosion was out of all proportion to the event, the dog gave one howl, bolted for the veld. Looking round to see if the terror was following, he knocked against a stump and rolled over-when he recovered, he went off as hard as ever, until out of sight, that was the last seen of old George Scheeper's "beef hound." We were in a fright as the old fellow was notoriously passionate, and we did not know how we could explain it away. When we got there I told old Scheepers the whole story of the dog's doings, in a ludicrous way. The old fellow laughed immoderately, when he suddenly asked "where is he now "and I said to the best of my belief he was still going strong in an easterly direction! so after laughing so much he could not well get angry, a "sopje" and a few pounds of coffee, tea and sugar to the old "tanta" cemented our friendly relations.

Old Jacobus Erasmus who lived at "Onderstepoort," adjoining the Pyramids, near Pretoria had a 
terrible accident one day. His herd boy came to tell him that a tiger (leopard) had killed some goats on the hill, at the back of the house. Old "Cous" took his dogs and went to see what damage had been done. On approaching the spot, the dogs found the brute and old Erasmus encouraged them to attack; when the leopard suddenly sprang clean over all the dogs, on to the old man, tore the scalp off his head right over his eyes and gave him some terrible bites on his head, neck and shoulders. The kaffir herd boy stabbed it with his assegai, and the dogs pulled it off, leaving poor old Jacobus nearly dead. It took him many months to recover. Many years, (about 30) after this his eldest son, Cornelius Erasmus, was bitten in the same way by a leopard on his winter farm in the Rooiberg, a strange coincidence!

It is wonderful what severe injuries men of robust constitution can recover from. Hans Delange, a notable old "voortrekker," whom I knew well, was attacked by a lion near Bronkhorstspruit. He had no weapon but one of the old-fashioned hunting knives called "Harnuter" ('Huguenot') as usually worn by the old Doppers. With difficulty he got hold of this knife with one hand, while the lion was biting his other hand and shoulder to pieces, and succeeded in stabbing the brute in the heart. Ho described most graphically to me how he forced the knife into the lion's chest, and then wriggled it about inside until he got to the heart. The old man was found nearly dead-the lion quite dead. His case was considered hopeless, but he was taken to the Warm Baths at Waterberg, where he recovered, and lived for several years, with his one hand and arm maimed and useless. The courage and vitality of some of these old, hard pioneers, was simply wonderful. I could tell many tales of their dealings 
with savages and wild animals, some of which might not be credited.

Commandant Frederick Giester, who had been a great chum of Alex. in the war with Semondo and the Zoutpansberg tribes, was now living on an outof-the-way farm near Deelkraal, south east of Marabastadt. I had exchanged a new wagon with him for oxen, which I had to go and select on another farm, some miles distant. He gave me a game little shooting pony to ride, but warned me to be back early, as lions had been very troublesome lately, and the pony would throw me off if he could smell any, as they had nearly caught him once or twice. I was detained rather late at the cattle farm. While on the road back it got dark and the old pony became very nervous. When about two miles from Geister's, while going through some thick bush, the pony bounded suddenly forward, fortunately keeping the road to the house, and on the instant a lion sprang at us. I could feel the wind of him on my back, as he missed his spring, owing to the alertness of the pony. Had I not been riding "tight" since the pony became nervous, I must have come off and then the lion would have lain down with the lamb, but with the lamb inside. If I had jerked the pony and checked him in his bound, his lordship would have had us both and overeaten himself. I was sorry for his disappointment, but charity begins at home! When I arrived at Geister's, he met me at the door and said at once "You have had an escape, the pony is wet with sweat and trembling all over," and I told him how splendidly the brave little horse had saved my life. He said, "Yes, he is alright if you can only sit him when he takes fright." In my case my fear of the lion was greater than of a pony bolting in the dark, so I sat him. A few days after 
this, a young Boer, who was riding from Duvenage's farm to Schoemansdal to have his banns called, was caught in daylight, not far from where I had my experience. When he did not return, they went to look for him, and found only his skull and portions of his horse and the broken saddle. It seems incredible that in the fifty years since then, the country has been cleared of all game, lions included.

A comical accident happened to one of my kaffirs on "The Willows." I had shot some fat quaggas out of a herd which came below the hill (to feed the working kaffirs), and one quagga I sent to old Rooibok, who was herding a lot of cattle on the adjoining farm "Hazeldean." My brother Ted, a couple of others, and myself, were playing whist in the old Boer house, before the new homestead was built, when we heard a loud report and yells of anguish near the orchard "Rooibok Weh!" "Rooibok Weh! yoh, yoh, malajoh !" Piet du Preez, my farming man, explained the situation. He had a patch of sweet potatoes near the orchard, and had set a spring gun to shoot porcupines which were eating them. Rooibok could not resist the craving for sweet potatoes to eat with his quagga meat, and had come three miles from Hazeldean in the night, and had commenced to dig some out when the gun went off behind him, peppering him sorely and sending him on his face, and he thought it was "Molimo" (God) punishing him for not being content with the quagga, so he shouted for mercy. Next morning the other boys spread him, back upwards on a large round stone and extracted as much of the shot as they could get at with a penknife, but he could not sit down or get about, so I paid him off and he went to his kraal. Some years afterwards he turned up with twenty followers, introduced 
himself as a chief, and undertook to build a stone wall about a mile long, which stands to this day. I paid him with heifers, so that he could increase his stock of wives! 


\section{CHAPTER XIV.}

\section{HYENAS IN A CAVE.}

There are some caves in the Dolomites, west of Pretoria, where a lot of hyenas had their lairs. They had killed some foals belonging to Hans and Rasmus Erasmus on Swartkop. The latter went into the cave with his gun (his Hottentots holding tallow candles), to shoot them, but the concussion of the first shot put the candles out, a hyena caught his hand and bit off two fingers. When he told me this, I determined to have a go at them, so Alex and I with six of my kaffirs, armed with ropes, lanterns, pistols, etc., went there. The kaffirs were afraid to enter, as we had to go down a steep, narrow passage before getting into the big cave, so Alex. and I went alone. He held the one lantern and I had a large pistol, a sword and another lantern. As soon as the hyenas saw the bright reflector lantern, they crept into crevices, lay and blinked their ugly big eyes at the light, which I held right in front of their faces, I shot them easily right between their eyes. I never gave any of them more than one bullet. They made horrid noises and snuffled about, but did not show fight. The concentrated light was too much for them in the dark cave, and the echo of the reports of the pistols frightened them still more. If they had had any pluck, they could have torn us to pieces, but they had not; I shot nine enormous brutes. We could not find more that day, and could not properly explore the inner cave, as we had no string to mark the way back, and if our lanterns gave out, we would be eaten if any hyenas remained unshot. We had trouble to get the kaffirs to enter the cave, although 
we assured them that the "Wolven Pirie" were all dead. It was quite hard work hauling the brutes out with ropes, up the steep entrance passage, as they were very large and fat, and it took us all the afternoon to get them out and skin them. The Kaffirs were much impressed when they was them lying dead, in the corners of the caves, and bragged immensely (when they got home with the skins) about their bravery in going into the cave for them! The skull and jaw of the African hyena is much more powerful in proportion to his body than that of the lion, and his teeth are immensely strong. When I had told Hans and Rasmus that I had shot nine they would not believe me until I showed them the skins. After a few days, having seen fresh spoor in the entrance, I went again; this time taking Louis Devereux with me to hold the extra lantern, but I only found and killed three, and again I went the last time and only killed one, after which we were not troubled any more by hyenas in the village of Pretoria, and the neighbouring farmers were pleased. The skins make excellent tanned leather, and neck "strops" for oxen. These same hyenas ate up all my buffalo "trek tows" one rainy night at Erasmus River (six mile spruit), while I was on my way to Natal and I had to delay some days while I got others from Pretoria, but I had my revenge. I have often shot hyenas in the bush-veld in the moonlight, while sitting under the wagon or sometimes under my shooting pony to hide myself, but if you hit one badly the rest rush on to the killed or wounded one, and eat him up on the spot. Next morning there is nothing but hair and blood on the ground. Alex and I amused ourselves one moonlight night near the Olifant River for a couple of hours, shooting them and watching the rest devour them. The howl of these ceatures in the 
still night, is weird and mournful to a degree. On my way to Natal one trip, I was travelling at night near Tafelkop beyond the Vaal River, the boy was in front leading my two fat, stable-fed horses; as I intended to leave the wagons next day, having shot enough game for rations and wished to drive on to Maritzburg in my cart. All at once I heard the boys shouting and ran forward in time to see the horses tearing off, dragging the boy (who had tied the end of the rein round his wrist), and following them a pack of about thirty "wolves" (hyenas). Fortunately, the rein came loose, the boy was released, but badly bruised and shaken, and my two beautiful horses disappeared in the dim moonlight, tied together, the pack in full cry after them. We could do nothing, so outspanned. My wagon driver, Ben Holder, and I, followed the spoor as close as we could till midnight, but could not overtake them; we met some of the "wolves " returning, having failed to catch the horses, so we shot one of them, the others bolted. The horses being tied together, had fallen over ant heaps once or twice. but had evidently escaped. Hyenas as a rule, do not hunt in pack except at certain times. On my return from Durban I found the horses in splendid condition at the farm of Jan Britz, he having found them while out hunting, and kept them for me when he learned to whom they belonged. The one cream coloured, "Buckley," was my favourite shooting horse, and I rode him for years afterwards. I saw that same Britz perform a wonderful feat of horsemanship. We went out to shoot blesbok, of which there were great numbers near his farm; he was riding an ugly little rat of a Basuto pony, and when racing full tilt, it put its foot into a hole and rolled over, Britz (who like all Boer hunters, rode with very long stirrups), standing almost upright in the saddle, 
without any knee grip, instead of rolling under the pony as he would have done, if he were riding tight, simply ran away on his feet again! When I expressed surprise at this he said, "Oh you soon get used to a horse falling in the veld, the only thing to do is not to stick to him." Whether he could manage quite so easily on a big horse going a greater pace I doubt. On this trip, my trap horses being lost as mentioned, I went on to my father's old Field Cornet Martinus Koekemoor, near Cornelius River, and bought his old shooting horse to ride on to Durban, as I had to see my sister Fanny Proes and her little boy off to Europe.

It had been raining for some time, and all the rivers were full; when I got to Cornelius River I found it had overflowed its banks. I put the horse in, but as he was not a good swimmer, he went far down stream and got into a hole filled with floating reeds and grass; I nearly got drowned in trying to get him out, which I did at last. After a rest, I had to swim back for my clothes, and, half perished with cold, had to ride to Mill River, which I also had to swim, as Koekemoor's house was on the south side. Beyond Harrismith, I had the same performance at the Wilge River, but from there to Maritzburg there were boats behind which the horse could swim. I got to Durban two days before the ship sailed and saw Fan comfortably settled for the voyage. 


\section{CHAPTER XV.}

\section{THE ZOUTPANSBERG.}

When I first went to Zoutpansberg in 1857-8, I was mueh impressed with the possibilities of cotton growing. A kind of wild cotton grew profusely all about that country, and of this the natives made coarse rugs and blankets, bags, rope, baskets, etc., There were also valuable wild fruits, the "Marulla" a large tree bearing a fruit like a greengage which the natives eat and from which they make quantities of a very intoxicating kind of beer; another very handsome large evergreen tree bears immense quantities of berries, shaped like big acorns. This they name the "Mafura" or fat tree and crush the fruit to procure a vegetable butter, which they use to anoint their bodies; they also grease reims, skins, etc. with it. Wild pisang (bananas) grow on the hillsides. The pea-nut flourishes everywhere, and when once planted it is impossible to get all the seed out of the ground when reaping, and it makes a "volunteer crop" for some years. Coffee grows fairly well in the Spelonken; tea would do excellently on the eastern mountain slopes towards Delagoa Bay ; rice is grown by natives nearer the coast, and tropical and temperate-zone fruits flourish. Maize and "Sorghum" (kaffir corn) and tobacco are the main summer crops. Wheat, barley, rye, oats, (the winter crops) grow under irrigation. The Zoutpansberg is a beautiful mountainous grassy country.

Unfortunately, the district has gone back instead of advancing in prosperity, in population, and in 
development, and it is sad to see the old one-time flourishing homesteads deserted and ruined, and the natives in possession, as they swarm into the district from the north and east.

It is a country which can and should carry a large flourishing population. "Go ed ew e ns ch," Albasini's old Estate was bought by President Kruger in 1890 to settle poor Boers on, but I have not heard if they have been successful. These settlements are not as a rule, as the class of people put on them will not work intelligently.

In the early days of Schoemensdal (a trading village under the Zoutpansberg), there was a recognised system, under Government permits, of supplying native hunters with guns, ammunition, blue salempore, brass wire and Venetian glass beads. Each hunter, according to his recognised value, was given a certain number of carriers to take his truck in, and the ivory out, and the hunters got a percentage on the ivory delivered. Some of these men were good elephant shots and made lots of money. Many Boer hunters went themselves, taking bearers with them. It was a hard life, fraught with danger. The hunters did not go in before the 15th of April or May, and were supposed to be back by October, before it got too hot. The guns in use were dreadful things to handle, firing eight, six and even four bullets to the $\mathrm{lb}$. The recoil made one's arm black and blue and green.

When Paul Kruger having made such a mess of his attempt to attack the Makatees in the mountains, fled with his commando, and left Schoemansdal and the district deserted, the Kaffirs kept all our guns, goods and ammunition etc., and there was an end of our trade and hunting. One year we sent out $32,000 \mathrm{lbs}$. of ivory, and on one occasion I traded in 
the Spelonk $3,000 \mathrm{lbs}$. of ivory in three days. The ivory trade never recovered from Kruger's unsuccessful attack on the hill tribes, and his ignominious retreat out of the district. When war was declared, these men kept everything, and the loss to the whites was very great. Zoutpansberg never recovered from that disastrous war.

During the annual petty wars in Zoutpansberg district in the fifties and sixties, native children were brought out and disposed of, the average value being about two hundred rix dollars (£15). A man owed me some money for a long time, and one day a wagon turned up in Pretoria with some ivory, some oxen, and one kaffir boy of about 12 years, in settlement of the debt. The boy was invoiced at $£ 15$; I did not want him, as I had always refused to have any of these captured children, but if I sent him back he would suffer, so I told him that he had been sent to me for as long as he wished to stay, but that at any time he wanted to go he was to tell me and I would give him a free pass. I had him well clothed and he was "tiger" in the cart, when I drove and he was very happy. That was the only instance of my dealing in "black ivory" as it was termed.

Two years ago, while on a visit to the Waterberg Warm Baths, an old man sold me a basket of fine oranges; he turned out to be Jasper Aitchison, whom I had known living in prosperity with Landsberg in Schoemansdal in Zoutpansberg forty years before. 


\section{CHAPTER XVI.}

\section{ALEX. STRUBEN'S TRIP TO ZOUTPANSBERG}

\section{AND THE ZAMBESI.}

In a copy of the newspaper South Africa, of August 31st, 1895, I find a short notice of my brother Alex's trip to the Zambesi. It says "Mr. Struben was the first white man to visit Umzila, the Gaza Chief, in his kraal (at the head waters of the Busi), from the Transvaal, if not actually the first white man there." It was in 1865 that he left Zoutpansberg. He crossed the Limpopo at the Pafuri Junction, and then the Nuanotsi, descended the berg, crossed the Lundi and Sabi rivers through country never before visited. He was badly received by Umzila, and cruelly treated. Some of his donkeys died (probably of tsetse fly bite), and he himself was stricken with fever. He regained Zoutpansberg after great hardships but was unable to recover from the effects and soon died.

"It is unfortunate that no particulars of this very interesting journey can be obtained." This was written by George Lacy in his "Explorers of South Africa," who also mentions Captain Shelley, who explored all about Lake N'gami in 1852. Shelley stayed with us in Ladysmith for some months, and Alex. used to listen with avidity to his tales of travel and hunting.

My brother, Alexander Betts Struben, who was in the Natal Civil Service, obtained leave of absence on account of ill-health, and in February 1863, left with me for the Transvaal. After spending some time with me shooting in the bush veld, he got a 
longing to explore the interior. He returned to Natal, and in 1864 sent in his resignation. The Secretary of State for the Colonies allowed him a retiring pension. After again spending some time in Pretoria (where our father then lived), he started on the 27th June 1864, from Zoutpansberg with natives and animals I had supplied, but he only got as far as the Limpopo, when his carriers refused to go further, as the "Knobnoses" or Shangaans were raiding the country and so he had to return.

I tried to dissuade him from attempting to traverse the unhealthy country north of Zoutpansberg; but he had listened to the stories of the old elephant hunters, and go he would, so the next best thing for me to do was to fit him out as well as I could. On the 10th April, 1865, he made a second start from Pretoria. When he reached Zoutpansberg, another local war between Boers and natives was on, so he left his ammunition at Rhenosterpoort, and went on with one wagon to Albasini's in the Spelonk. I had a number of natives living on a farm of mine near the Livubu river; and these natives I gave him for carriers, and here he had a hut built and stayed while the war continued, until he could proceed into the interior.

In June 1864 he received the goods sent to him in Zoutpansberg, guns, ammunition, medicines, tools for gun repairs, drawing materials, presents for the native chiefs, thermometer, field glasses, air mattress, tent, etc., but this trip never came to anything on account of the war with the kaffirs. The hunters could not go in for two years and the elephants came near to Zoutpansberg. The kaffirs had driven the Boers out wholesale, and hunting and trading were impossible. 
In 1865 the Transvaal Government tried to patch up peace but failed. The native hunters had, as usual, got all the guns and ammunition from the Boers for the year's hunt, and when they found that there were no more to be had, they declared war and joined the hill tribes.

Alex's diary for 1865 is interesting as showing the barbarous life and mode of warfare on the frontiers of civilisation. Albasini, the Portuguese Consul, trader and kaffir chief, was ruined by this war; and many accounts owed by people in Zoutpansberg could never be paid to my father. Alex. was detained five months in the Boer laager, and his substance frittered away. They were six weeks without bread and lived on musty kaffir corn ("Sorghum:") $\mathrm{He}$ had eventually to walk to Pretoria. In April 1866, he was still at his hut near the Livubu, unable to go in, as the kaffirs wou d not give up the guns, while the Government sent a commando from Pretoria. This was under Commandant Paul Kruger. They made a futile attempt to take the mountain strongholds, but retreated routed. Kruger gave the inhabitants three days to take away (from the village of Schoemansdal and the farms) as much as they could, and then retreated "en masse" to Rhenosterpoort. As soon as they left, the kaffirs burnt the village and all the farms near the foot of the mountain. Alex. sent out what cash and ivory he could muster to pay me what he owed but always refused to take payment in so-called "black ivory" (little captured Kaffirs), as neither he nor I would have anything to do with such traffic, although it paid well and was everyday dealing at that time. After wasting about three years in vain attempts to get into the interior, he eventually started with an induna of Mazila's for guide. He took part with the Boers in attacking 
some strongholds and was given command of their solitary 24 pounder carronade. Before the Pretoria commando arrived, the Boers were only about 150 strong, but the Makatees were cowardly or they could easily have wiped them out. Some of his descriptions of these times, 1863 to 1866 are not pleasant reading. The cruelties of the savages on both sides, countenanced by the whites as far as their allies were concerned, were dreadful,-flaying, mutilating, burning, etc., especially in the fights at “ Katlakta's," "Simondo' ," “Magor's," “Lobola's Kop," etc.

A comical event happened as related to me by Alex. with Commandant Geister. There was one of the annual little wars on, with the tribes in the forest clad Zoutpansberg, this time with Simondo. The Boers and Albasini's Knobnoses had dragged an old 32 pounder ship's carronade up the mountain to bombard the kaffir "schanses" or stone walls. A few shots proving ineffectual, the kaffirs made a sortie, and the commando fled round the mountain, leaving Geister, Alex., one Venter, and some Knobnoses to get the cannon down as best they could. Alex. was gunner for the nonce, and while he was firing some shots to keep the kaffirs off, Venter jumped on Alex's horse and fled after the commando, knocking several people over in the narrow bush path on his way to camp. Geister, Alex and the Knobnoses then pushed the cannon into a bush kloof and retreated, keeping the kaffirs off with their rifles. On arriving at camp in the evening, Alex. asked Venter, (who was a tall, ungainly "takhaar" with a head like a bassoon), what he meant by taking his horse and leaving Geister and himself in the lurch? Venter solemnly answered "Mr. Struben, don't be angry with me. I am a man of peace and don't want to quarrel. I 
am a very brave man as a rule, but when I get really frightened, nothing stops me, when once I start to run." ("Ik skrik niet makkelik maar als ik skrik dan skrik ik leelik.")

Dear Alex. wrote some comical anecdotes of his Zoutpansberg experiences and made several water colour sketches, but unfortunately, nearly all of these were lost in Natal.

One day, while on his first trip to the Limpopo, his horse got among a troop of elands that were rushing past the wagon and was never seen again. I notice in his diary June 16th, 1863, "Philip Bronkhorst badly torn by a lion" and further "Minnaar found in the bush with both his arms bitten to pieces," showing how frequent these accidents were, in fact in the fifties and sixties they were still of constant occurrence.

The village of Schoemansdal was prettily situated under the beautiful wooded mountains, with running water in the streets and there were some fine farms in the neighbourhood, but I have never been there since 1865, when the elephant hunting was ruined.

When Alex. finally did start for the Zambesi he had two horses, eight donkeys, sixty Kaffirs, guns, tent ammunition, and goods to trade for ivory and food His companions turned back at the Limpopo. On reaching Mazila's, Quhugenyana's father, the rascal, levied blackmail for permission to shoot elephants in his country, and then sent a commando to drive them all over a certain river, which Alex. was forbidden to cross. When Alex. found this out, he did after a time cross, and shot 32 elephants. Then Mazila sent a commando to catch him, but they failed to come up with him, and eventually he reached the Zambesi somewhere between Zumbo and 
Tete. As I say, many of his memoirs were lost and I am not certain as to the details of this trip, but he was certainly the first white man to reach the Zambesi from the Transvaal.

On his return journey, he tried to avoid Mazila, but the Kaffirs had instructions to take him to the head kraal, where Mazila took most of his things from him, and kept him so long that he got malarial fever, of which he died after reaching Pretoria. I had heard nothing of him for so long, that I sent my trusty old natives "Klaas" and "Jonas" with a wagon and comforts to go as far as they could (for tsetse fly) and try to find him, which they did near a Mr. Heanert's farm in the Spelonken, where be had just arrived, very ill. These good people were very kind to him until he was able to be put into my wagon and come on to Pretoria. Alex. told me that he got on fairly well until the "tsetse" fly killed first the two "salted" horses I had given him, then one after another the donkeys, until the old donkey stallion (skin and bone from fly poison), carried him to Seguarragwarra's on the Limpopo, whence he was carried partly by bearers and partly in the wagon to the Spelonken. It was pitiful to see him shivering with ague and fever in the hottest weather and covered with blankets. 


\section{CHAPTER XVII.}

\section{BOER "VOORTREKKERS" AND COMMANDOS.}

The Dutch farmers ("Boers") who trekked from the Cape Colony in 1836-7, were probably the most resourceful, confident, and brave pioneers the world has produced. They had vast tracts of fertile country at their disposal, to graze their stock or to cultivate at will and they led a more or less nomadic life. With enormous herds of antelopes to fill their larders, they could command native labour, which cost little or nothing, and notwithstanding the dangers and hardships incidental to occupation of unexplored wilds, the healthy open air life in a glorious climate, with its daily exciting experiences, appealed to them. The children were born and grew up on the veld and inherited the restless trekking spirit. When the game was destroyed, and the land became occupied, many of the pioneers and their descendants found it difficult to conform to the more settled conditions. Native labour became less plentiful and more expensive; there were not adequate markets for any stock or produce they had for sale; the farms they obtained (without direct payment) had but little value in their eyes and were frequently sold for a few pounds and the former owners became landless and poor. Again, under the Roman-Dutch law of inheritance, similar to the "Code Napoleon" the larger farms, which supported a numerous family, were sub-divided on the death of the parents among the children. They could not all make a living on these small portions of the original farm, and piece by piece the ground was sold to strangers, A typical 
case of how the Roman-Dutch law affects the prosperity of the country came to my notice. A fine old farmer, Izaak Bretenbach of Leydenburg, lost his first wife and as he wished to marry again he proposed to divide half his estate among his children. $\mathrm{He}$ had quarrelled with a worthless son-in-law who would accept no land, stock or anything, but demanded that the estate be put up for auction. Bills were accepted in payment and these were eventually paid in Transvaal notes (at par £1,) while worth only $2 / 6$ and the old man was ruined.

In the old days of the "Trek" from Cape Colony in 1836-1837, the trekkers were like one big family and wiled away the time when not fighting savages, shooting game, or holding religious services, by playing games and practical jokes on each other. At one laager in the Transvaal, there was a notorious old gossip named Venter, who would bore his friends with interminable prosy stories and keep them up till late at night. He rode a little white mare which had a habit of starting off with a rush for a few yards as soon as mounted. One evening, while old man Venter was holding forth, a couple of young fellows loosened the girths of his saddle and tied a long bullock "reim" to the crupper, the reim being kept on the off side, the rascals obsequiously holding the mare in position, for old Venter to mount. The long-winded yarn ended and "Slaapgerust" (Sleep well !) followed, Venter mounted, thanking his two young friends for so politely helping him to mount. Off went "Saartye" at a bound, the reim tied to the wagon became taut, old man Venter came flying off behind, and sat sprawling on the ground, much astonished and discomfited, to the immense amusement of his late weary audience. "Ya," said one old sport, " dit zal hem leer om niet so langdradig te 
praat." ("Yes, that will teach him not to be so longwinded,") old Venter saw the joke in time, and sought a more appreciative lot of cronies to spin his yarns to.

To-day it is to me a sad sight to see the descendants of families whom I knew some years ago in comfortable circumstances, now living in degrading poverty, and deteriorating physically and morally, without energy for the work of the day or hope for the future. The only chance of bettering these poor people is to educate the children, and teach them self-respect and the dignity of honest labour, not to despise work or service as only fit for Kaffirs. If the landless people of white descent do not become industrious, the natives will take their place and they will die out. It is to be regretted that the Dutch Ministers of religion, who in some ways so strongly influence the Dutch constituents politically, have not been able to do more for the so termed " poor white" section of the race, industrially.

In 1856 I was commandeered to go on commando against Mahura and Gasibone in the Batlapin country. I took my own wagon and oxen, and Matabele servant, so as to be comfortable, but to my disgust they quartered two fellows by name Piet Viljoen and P. Du Preez, on me. They "sponged" on me until I could stand it no longer. One night, while there was a prayer meeting going on, they stole all my biscuits and filled a large chest they had. When I found them out I shamboked Du Preez, and was court-martialled for cutting him about rather worse than I knew. He was a powerful man, and tried to grapple me, but I managed to keep him off until he was tired of being punished. He then complained to the Commandant who imposed a fine of $£ 60$ on me, instead of restoring my stolen 
provisions! I next day left the commando and laid the case before President Pretorius in Potchefstroom, who at once gave me a fat slaughter cow and a bag of wheat meal which Mrs. Botha the mother of Cornelius Botha (afterwards secretary to Mr. Paul Kruger), made into bread and cakes for me. I waited in Potchefstroom until the contingent arrived, when the case was tried and the $£ 60$ fine imposed was remitted, and the Commandants and other officials reprimanded for their behaviour at the front, so I got off with flying colours! There were some good fellows on the commando and as it was a new experience for me I enjoyed it, but it was pretty rough and the horseplay sometimes dangerous. One joke was tossing a man in a freshly slaughtered ox hide and it was a sickening experience for the victim. I was never subjected to it.

While waiting at the Mooi River for the Mahura commando to come up from lower Vaal river, a contingent from the Elands river Ward arrived and joined my camp, they were mostly Bezuidenhouts and hunters, a jolly lot of fellows and they had music and dancing on the grass in the moonlight every evening. You never meet that light-hearted, rollicking class of Boer now. When the Pretoria section of the commando turned up, the leaders were sulky because I had worsted them with the president, but by a judicious application of gin to some, coffee and biscuits and fat biltong to others, and a cheerful face, we were soon friends again. In the evening, all kinds of rough outdoor games were played among them. One "Stok-Trek"-when two men sit opposite to each other, on the ground, their feet against each other, a stout stick held by both, the one who is pulled upright or forward loses the game, and a small prize is awarded. Willem Horn had 
lately married a sister of Joseph Fourie, a spinster of uncertain age with a "wall eye," she was known as the "oude nooi," ("old maid.") I generously offered to "trek stok" with Willem for his "oude nooi," he was irate, but being chaffed by his friends, he risked it. I pulled him up and claimed the "oude nooi" most seriously, this got on his nerves, and he slunk away from the laager in the evening to walk home at Horn's Nek in the Magaliesberg. When he reached Sarel Du Toit's farm (near where the "Jameson raid" party were first attacked many years later) the dogs drove poor Willem into a dry ditch, keeping him there in the bitter cold till daylight, when the commando came along and we got him out. In consideration for his sufferings I promised to waive my claim to "de oude nooi," and he no doubt wrangled with her happily ever after.

On this commando the oxen contracted foot-andmouth disease, when the poor animals could hardly travel, and many died of starvation, as they could not eat the dry grass. The commando was a failure. The time and energy wasted over these frequent commandos prevented the country progressing. During the Boer Civil War of 1864, Rensberg's commando was expected. They made my father Commandant and our verandah was full of warriors, sleeping. I relieved Lys, Broderick, and others from guarding the powder magazine, but told them not to be disturbed if they heard shots during the night. About midnight, our guard (some armed with elephant guns) let off a couple of volleys, and the panic in the town was immense-it was lovely!most of them stampeded into the yard behind the house! it was not until order was restored that I could get to bed. My dear old father was annoyed with me when I could not give an account of $\mathbf{m y}$ 
guards firing, and I had to confess that it was an experiment in alarm drill. I was sorry it was not appreciated, but it had its moral for the "park of artillery," (two 32 pounder ships guns), could easily have been spiked when they were deserted outside the old Court House (where the Law Courts now stand on Church Square).

I had several queer experiences during this war. I never could make out what they were quarrelling about. Rensberg's Government adherents would occupy Pretoria and commandeer sugar, coffee, etc., and then Schoeman's lot would come in, and the others would clear out; and the commandeering was done all over again. I had no interest in the matter, so paid both sides and was allowed to continue my journeys to Natal as usual. On my return from one trip I heard that Schoeman's commando was at Block Drift on Vaal river. My wagons were outspanned at "Turf Sluit" on the Pretoria side of the river, when who should ride up but Field Cornet Jan Kock (who was afterwards as General Kock killed at Elandslaagte.) $\mathrm{He}$ had come from Schoeman's laager and said that he wanted gunpowder. I had a large quantity in one wagon, but pretended that I thought he wanted a little for game shooting, so I ostentatiously emptied my powder flask giving him more than half, saying that I must keep a few charges for springbok near Heidelberg. He said he thought I had a quantity, but I asked him if he thought I would risk taking ammunition about in war time. I gave what I had to him so cheerfully, that he was misled and rode back to the laager. As soon as he was over the rise, I "inspanned "at once, gave all the boys a stiff glass of gin, told them to keep up to my leading wagon, and anyone causing a stoppage would be punished, we did go all that long night, the boys being primed 
now and then with gin and biscuits. One wagon stuck in a mud hole near Zuikerboschrand at midnight, but I put double spans on, and as the sun rose we passed Gabriel Jacob's, safe in sight of Heidelberg, where friendly forces were lying. I heard afterwards that Kock was laughed at in the laager for being hoodwinked, and that a strong horse patrol sent to catch me, turned back on the Nek above Gabriel Jacob's, when they saw my wagons near Heidelberg. They might have overtaken me, but turned back at once, as they thought I could not have travelled so far, and that they had missed me somewhere in the dark. If they had taken all my ammunition I should have been half ruined, as they would never have paid for it. The old Boers say that when you can't fight you must run hard, but begin in time. I thought of that then, $\mathrm{Ha}$ ! $\mathrm{Ha}$ ! and I did run and no mistake. All this happened later when the Transvaal was getting "civilised" and troublesome. I preferred the old simple times.

During the quarrel between the Free State and the Transvaal, I was outspanned at Mill River with some wagons on the road from Natal. One of the wagons had $2000 \mathrm{lbs}$. of gunpowder on it, intended for Pretoria and Zoutpansberg. This was reported to the Free State authorities in Harrismith (which place I had avoided), and suddenly a Field Cornet and some men rode up and ordered me to inspan and take the wagons to Harrismith as they wanted the gunpowder and lead. I ordered the boys to bring up the oxen and inspan, in the meantime giving the gentlemen coffee and conversation. When ready, I ordered the men to drive along the road to Pretoria and loosened my rifle and told the Field Cornet that if he hindered me I should be compelled to shoot him and some of his friends, so after some bluster 
and threatening to stop me further on, with more men, they asked me to give them an undertaking not to sell any south of the Vaal River. I did this, and they rode back to Harrismith, much crestfallen. I travelled hard expecting them to collect men and follow me, but I never saw them again, and got all my wagons safe into Pretoria. 


\section{CHAPTER XIX.}

\section{COMMANDOES AND CIVIL WAR OF 1864.}

While I was living with President Martinus Wessels Pretorius, to learn farming, I got to know and to like an old Dutchman, named Jan Visagie, who was better educated than most of the Boers in the Transvaal and was a medical man of sorts (dispensing simples and Dutch patent medicines). $\mathrm{He}$ had a keen sense of humour and I had many a good laugh with him. He became secretary to Government and moved to Pretoria. When during the Civil War of 1864 Schoeman's party entered Pretoria, they seized Visagie, said his books were not in order, and that he must find security for his appearance when called on, or be put in prison. I stood security for the good-natured old fellow, and produced him in Court on the appointed day. Hans Steyn was appointed judge by his party; and one Swart Martinus Pretorius declared Visagie's books to be out of order and money missing and demanded that, as I was security for Visagie, all my estates should be confiscated! I pointed out that I only undertook to produce Visagie in Court, which I had done, and there my liability ended, but it took all the oratory at my command to get me out of their clutches. I forget what they did to old Visagie, but I think they bolted soon afterwards, as the opposing commando was coming to town. I had built a burnt-brick house some time before (I think the first of its kind in Pretoria) which I afterwards leased to Government Secretary Van der Linden. This house was taken by the Government "de jure" and used as a guard house in which they kept their political 
opponents. Pretoria used to be taken and evacuated by the opposing commandos without a shot being fired, but there were "excursions and alarms" in plenty, and each incoming commando camped on the Church Square, made requisitions for slaughter cattle, meal, coffee, sugar, etc., and made a most horrid mess of the place. One time, Rensberg's (really Kruger's party), had given me a pass to go with wagons to Natal. I sent the wagons on with John Lumsden in charge, and my youngest brother Fred (on his way to school in Maritzburg), accompanied him. I followed on horseback, and came on a laager of Wakkerstroom Boers under James Henderson,- - a wild, unruly lot. While I was talking to them and telling them that their side had lost the fight on Moselikat's Nek, Magaliesberg, one Boer tried to seize my horse's bridle, but I galloped off and was soon too far for them to catch me, as their horses were knee-haltered and grazing. Someone shouted out "shoot him if he does not stop," but I was soon over the rise, too soon for them. On overtaking the wagons near Heidelberg I found Lumsden ill. A big Boer had knocked all his front teeth out because he told him that the other side had beaten theirs, and that several of their lot were shot. Had not an old Boer dragged him away, the wheel would have gone over him where he was knocked down. As I never could find out what these two Boer factions were fighting about, and they did not quite know themselves, I did not take much interest in the game beyond getting what fun I could out of it.

In the early sixties a small syndicate in Pretoria smelted galena at Broederstroom, and sold the argentiferous lead to the hunters for bullets at 1/per lb. ; but it did not pay, and soon shut down. I, 
at that time, sent samples of very rich iron ore to England but no one would take any interest in it.

This Civil War wasted much of my time, and cost me a lot of money-when I could ill-afford it. The Boers liked being on commando, the inconveniences were what they were accustomed to in daily life, they had not to do any hard work, got plenty of leave, etc., and had congenial company, but to the men who had business to attend to, and did not affect the rough commando life, it caused inconvenience and loss. In the early days of the Transvaal these commandos, against some native tribe or other, were almost of annual occurrence, besides the more serious wars among themselves, with the $\mathrm{H}$ ree State, or with the British Government. It goes without saying that subject to such a state of chronic unrest, the country could not progress.

We had some comical scares in Pretoria at night, but no serious danger, and after a few men were shot in the fight on Mosilikat's Nek, peace was declared. At one time I was commandeered with wagon and oxen and servants, to go with a contingent to Paul Kruger's farm near Rustenberg. I was placed in command of the artillery (one old ship's 32 pounder "carronade" on wagon wheels), a most dangerous weapon for the artilleryman-the enemy were fairly safe! I was much disappointed that it never came into action, as it might have made history! A truce was proclaimed after much parleying, and we returned to Pretoria. The Crocodile River was full and the commando outspanned. I got a plug made for the muzzle and one for the touch hole (which was nearly as big), and with my own natives and oxen went gaily into the stream, and nearly had the whole concern swept down into a deep pool below the "drift;" but both my boys and I could swim 
well, and we got across. I was ordered to wait for the commando (which crossed later), and was censured for risking the artillery so recklessly. On the south side of Horn's Nek we "laagered." I was told the gun would not go off after being submerged. To prove that it would, I aimed at a bush on the side of Magaliesberg, over the heads of the many spans of oxen grazing below, forgetting that with the best intentions towards the enemy it was loaded with home made grape and cannister! Ma conscience! I got a fright when all the ox herds fell flat and the missiles rained dust among the oxen and started them off. A court-martial was held, and I was informed that while the country was deeply grateful to me for my patriotism, and self-sacrifice, my reckless behaviour in the Crocodile River, and again in so wastefully firing off Government ammunition, as I had just done, (endangering the lives of Kaffirs and oxen) they were regretfully obliged to relieve me of my command. Did I feel downhearted? No! The gun was handed over to Moritz Preller on arrival in Pretoria, and he, rash man, fired it off to see how it would shoot. The charge came out at the wrong end, a piece struck him below the belt, he studied Transvaal artillery in bed for several weeks, and never quite recovered his health. One piece nearly killed my servant Ben Holder. So not hankering after too much honour and glory, I did not volunteer to run another "park of artillery." It was rather a different story when (about forty years later) Mr. Kruger, with three millions of revenue derived from the Rand Gold Mines, imported the best Krupp and Creuzot guns to fight the British, when he invaded Natal 1899-1900.

Acting President Rensburg's commandos and those of Stephanus Schoeman alternately occupied 
Pretoria. I knew nothing of the supposed cause of the war but I was on the Government side. When they commandeered my house, and put several of the other side in the stocks, among others P. J. Marais, Barend Pretorius, a little Hollander "Lastdrager" etc. I used to visit and cheer them up with jokes, but they said that jokes were of no use to them, while they were in the stocks. Barend Pretorius, who, when at liberty, was much given to talking big, was specially low-spirited and wept bitterly. Little "Lastdrager" jeered at him for being such a coward, and incensed the jailers by chaffing them. Everything was topsy-turvy, business at a standstill and Boer patrols riding about the country, instead of attending to their farms.

During these unsettled times we in Pretoria had some amusing experiences. One night Piet Marais, some others and myself were told off to guard the powder magazine, as Schoeman's commandos were expected to seize it. We got some fiddles and gin and warmed up the guard with dancing, melody and "squareface." In the night we let off a volley, the Commandant, Nikolaas Smit, and the whole town turned out in alarm. While the military council were investigating the cause of the stampede I slipped round and took all the gin out of their quarters as we had run short. I never drank spirits myself but my guard were thirsty, so I had to keep them up to the mark. Later, after the commotion subsided, we explained that we thought we saw horsemen approaching the magazine and prepared to sell our lives dearly. It was a touching oration and brought tears into their eyes, especially when they discovered, that, in the stampede someone had annexed all their gin and on such a trying occasion. While old Hans Steyn was presiding on 
the Bench (before the other commando approached when they all cleared out), one, Swart, was haled to justice all the way from Swartruggens for improper and immoral conduct, Commandant Andries Van Der Walt commandeered some of us to keep guard over Swart for the night and hand him over to the authorities in the morning, and as guard house, we were given the cottage of a widow who was an intimate friend of old v.d. Walt, who was a great sport. P. J. Marais, myself and several others, collected all kinds of musical instruments and the inevitable gin, and made night hideous with discord. We impressed upon the prisoner the importance of his taking some gin and this was repeated, notwithstanding his protests, until he was unable to escape, and he was then sat up against the wall on the floor. I am ashamed to say that one perverted spirit discovered a bucket of eggs, and a brilliant idea struck him that a target made with charcoal on the whitewashed wall would give excellent practice if drawn immediately above the head of Swart (which was all hair and teeth). Strict instructions were given not to hit Swart, but, unfortunately, some were out of practice and missed the target, and some perfectly "good eggs" caught him in the eye and elsewhere, and marred the beauty of his black beard! It was disgraceful, but after target-practice he fell peacefully asleep, and the guard danced "Sir Roger de Coverly " in the moonlight, with much music and noise. About midnight I spied the Commandant coming along so I blew out the lights, told the fellows to keep quiet, and I waited until he was inside the cottage; when I threw him down, and sat on him, holding him by the throat and shouting at him "You would try to escape would you"! pretending I thought he was Swart. He gurgled that he was not Swart but our Commandant. I ordered 
candles to be lit, when I saw who it was and said "boys it is our Commandant, our prisoner is safe." I helped him up, apologising for the rough time I had given him in the cause, and knowing his weakness for a sopje," plied him with gin until he was merry. He then requested us to play "Home Sweet Home" and after an encore we sent him back to his house with an escort. Next morning when he produced the prisoner in court, old Hans Steyn wanted to know what was wrong with him, as the target shooting had given him a "snuff and butter look" but as no satisfactory explanation was forthcoming, he was ordered to the water furrow to wash, before judgment could be passed upon him with proper dignity. The judge, who like necessity, knew no law, and besides spoke through his nose, dilated on the gravity of his offence, and confiscated his entire estate. He would no doubt have given the proceeds to the State had time permitted. These were days when it was wise to "agree with your adversary quickly while you were in the way with him," as self-made sporting judges were, at best, somewhat risky. A case in point is as follows: Scheepers of Sterkfontein was on a trading trip to the Free State and his second wife quarrelled with his son-in-law, living on Grobbelar's Farm "Honing Kloof." On the return of Scheepers, who was a violent man and powerful, she told such a tale about her son-in-law, that Scheepers rode over early in the morning, and thrashed the poor son-inlaw unmercifully with a bullock sjambok, while he was in bed. Wife No. 2 (who was still not satisfied) worked Scheepers into a rage again, so he let his son-in-law know that he might expect him early next morning to repeat the dose. He burst open the bedroom door, and the son-in-law, a small weak man, unable to cope with the enraged Scheepers, jumped on to some bags with an old pistol, and in 
self-defence fired, hitting Scheepers in the shoulder, from which wound he afterwards died. The son-inlaw was put in jail, tried and convicted of the murder of his father-in-law and was hanged in Pretoria. It appeared to be a heinous offence to shoot a fatherin-law under any circumstances. Had it been a mother-in-law there might have been extenuating circumstances.

The patriarchal Government of the Transvaal during the fifties and sixties was often amusingly primitive. The first Landdrost Joachim Prinsloo, a real good type of an honest old "voortrekker" and a kind-hearted hospitable man whom everyone respected and liked, when discussing one day the collection of taxes and disbursements, admitted that he found difficulty in keeping books, but after paying his own and other salaries, the balance went to the Government. He said this in perfect good faith and in his case no harm was done, as he had not much to administrator, and he was scrupulously honest, but the system would not work well under conditions obtaining now. A burgher was condemned to be hanged at Potchefstroom, he was placed on a wagon which was drawn under a gallows, like a slaughter pole. He was blind-folded and the rope placed round his neck, when the wagon was pulled from under him, but the rope broke, and he fell to the ground. He had all along declined to believe that they would really hang him and when he recovered from the jerk he received, he said, "It's all very fine to pretend to hang me, and a joke is a joke, but you hurt me." They apologised for the accident, but put him again on the wagon with a stronger rope attached to him and he was legally executed, no joke this time. A notorious horse-thief Breytenbach, spent much of his time in 
jail, when not actively employed in stealing horses,in the hope of getting in again. He used to visit my place at, times, when I invariably gave him a small present in cash, tobacco, etc., as I kept good horses in the stable to which he might take a fancy. He never stole from me, partly on account of our friendly relations and partly because he thought I would shoot him. He camped for some time on the hill at the back of my house, and we could see his fires at night. He stole sheep etc., from my neighbours, but nothing from me.

One Christmas eve he obtained leave from the jailor to visit his family in the town, promising to return at sundown. He was late in getting back, finding himself locked out, next morning he laid a complaint, at being wrongfully kept out of his rightful quarters, in the jail.

During the time of the annexation 1876 to 1880 , a proper system of administration was established; and since then the country never quite reverted to the crude methods of the previous period.

Many stories could be told of Mr. Paul Kruger's early exploits, and others of later years. When a young Field Cornet he gained fame by standing on his head on the gable of the Dutch Church in Rustenberg, he also had visions and went for a time to the Magaliesberg to commune with himself, seeing visions, etc. After the Kaffirs in the caves of Makapan were all dead, he was the first to enter the cave, the stench from the corpses being dreadful. When after Majuba, he was returning to Europe to obtain a modification of the convention of 1880 , a large dinner was prepared for him at Edgson's and about 60 of the leading men of the district were invited to meet him. Mrs. Kruger had come from 
Pretoria to meet him, and they went into an inner chamber. $\mathrm{He}$ did not turn up at the dinner, and said they could send some food in to the room for him. He cared nothing for conventional usage. I had occasion (as President of the Land Commission) to settle a dispute as to beacons, between a fine old "Dopper" Voortrekker, Dolf Holsthuisen, and one Boshoff, and although I felt that the latter had taken advantage of the farmer's simple-mindedness, the evidence of the land inspection and witnesses compelled me to give judgment against Holsthuisen. With tears in his eyes, the poor old man thanked me for having done my best to obtain justice for him, but that he saw under the Government of the day, the laws of the land were no good, and he and his family and relations would leave the Transvaal. He organised a trek, his wife and many of his family died en route and the remnant settled at Humpata in Portuguese Angola. The courage and patient endurance of these old Dutch pioneers, in committing themselves with their families to the wilderness and conquering nature, wild beasts and savages to attain a goal has never been surpassed, and it is pathetic to reflect upon their struggles and sacrifices for an ideal. 


\section{ChAPTER XX.}

\section{BRITISH AND OTHER EUROPEAN PIONEERS AND VISITORS.}

After we had been in Pretoria for some time, other Europeans came to reside there, among them John Robert Lys with his cheery anecdotes, his unbounded and genuine hospitality, his ingrained loyalty to the British Empire, and his downright honesty in public affairs. Mauch the explorer used to be much in Robert Lys' house where he came with the dear old hunter and pioneer William Hartley, who was afterwards killed by a rhinoceros, in what is now Rhodesia. $\mathrm{He}$ took the traveller Mauch to the Zimbabye ruins. Thos. Baines ( the first to paint the Victoria Falls,) a quaint, unassuming, but sterling man, was one of the first to obtain a concession from Lobengula. He was given more to geographical and scientific research, than mere money making. We enjoyed his visits to Pretoria and "The Willows." Alexander McKorkindale, another real pioneer, who endeavoured to introduce British settlers into the Transvaal, and connect it with the nearest sea port. $\mathrm{He}$ obtained from President Pretorius large tracts of land in "New Scotland" district, near Lake Chrissie, eastern Transvaal. The higher portion of this land, named New Scotland, was dotted over with lakes, some so deep that hippopotami lived in them and the district was considered by the Boers too swampy to farm on. Of late years, the lakes have shrunk, some almost dry, and heavy wagons now go over on dry ground - what were formerly swampsand "vleis." The 
other part of the concession was on the lower terraces towards Swaziland called Roburnia. McKorkindale undertook to import white settlers to occupy this land, and was to open up a trade route to the Southern portion of Delagoa Bay. He often used to stay at "The Willows," when travelling between New Scotland and Pretoria, and gave me a very unfavourable idea of the thankless task of trying to settle emigrants on the land in South Africa. These Scotch peasants, judging from McKorkindale's statements, who were used to privation and hard work in their own country, were not satisfied with anything while they could claim what they wanted from the Glasgow Company and would do nothing to improve their own position. Eventually, when he died, and the settlement was disbanded, many of these men (when thrown on their own resources) did quite well for themselves. The land has been sold in farms; and thus the company may have repaid their outlay, while the district is filling up ; partly occupied by settlers under Lord Milner's scheme after the war, partly by Dutch and English farmers. McKorkindale died of malarial fever contracted on the island of Injak, Delagoa Bay, while waiting for a vessel bringing him freight from England. He was an enthusiastic, courageous pioneer of the best sort, but troubles and anxieties proved too much for him. I remember Anthony Trollope, the novelist, in 1877, being angry with me for saying, I did not think he should write a book on South Africa, until he had studied the life and conditions of the country outside Government House, and apart from blue books. Sir George Colley stayed in Pretoria and passed on to Delagoa Bay on foot. Some years afterwards he was commander-in-chief in Natal and was in command at Ingogo, Lang's Nek and Majuba, where he was killed. 
Although Pretoria was the seat of Government, President Pretorius lived in Potchefstroom; where he had a wagon-maker's shop, his house and gardens ; as he said that he had no property in Pretoria. As an inducement to him to reside in Pretoria the towns-people and officials appointed a special committee in which (John Robert Lys and myself were included) to select a piece of ground suitable for the President's residence. The President went with us, and the ground now known as "Skinners Court" was chosen, It was understood that it was for the President in perpetuity; not as a gift to an individual. I am not aware that any money was granted for building, and Mr. Pretorius made it over to Mrs. Skinner, in settlement of an account for board and lodging. The good natured old fellow was always hard-up, and when I saw him shortly before his death, at Maquassie, after his resignation on November 21st, 1871, he was in great poverty; so different to the simple prosperous days on Kalkheuvel where I stayed with him. 


\section{CHAPTER XXI.}

\section{EARLY FARMING STRUGGLES.}

In 1862 I purchased "The Willows" a farm near Pretoria and started farming, but it was slow work, as there were no markets for produce, and no money in the country; while the Transvaal paper issue represented $4 /-$ in the $£ 1$; and I found difficulty in paying the working hands. The losses from lung-sickness among the cattle, from horse-sickness and from hail, locusts, and other causes made it a hard struggle ; but by dint of work and perseverance, I managed to pay my way and to acquire some property from time to time. Shortly after this, I was practically ruined by the wrong-doing of a business firm ; and had to make a fresh start. It was uphill work, and a cruel blow just as I was getting on. After a time, I recovered and began to make my way again.

In January 1868, I married Mary Cole, daughter of the Reverend William G. Cole of Trinity College Dublin, a pretty little English girl with auburn hair and honest, trustful eyes. All our children, except Frank, were born at "The Willows." We had to work very hard to economise to keep out of debt with a large family to bring up; and the dear little mother, besides all her other duties, found time to educate her children, and keep up her own music, until they were old enough to go away to school.

In the winter to have a rest and outing, we used to make a little trek to the bush-veld farms on 
Sand River; and to see how the livestock were getting on, and we and the children enjoyed the camping out in a quiet way. My brother Ted and his wife were on another of my bush farms, Klipgat, close to us, camped under an immense wild olive tree; near a spring. One winter the Schoemans, who have their grazing farm adjoining mine on the Sand River; had lung-sickness among their cattle and allowed them, (the sick ones) to run all through my farm, where I had a large herd of splendid half bred Devon cattle. I went to them and complained of this, and they said that they had no Kaffirs to herd them. Seeing that I could not rely on them keeping their sick animals out of my veld, I undertook to pay the two native herds if they would promise to "kraal" their stock at night. This they promised to do, but they used the two herds to skin dead cattle, to work about their camp; and allowed their cattle to roam at will as before. One morning several of their sick oxen were standing at the gate of my "kraal" and evidently had been during the night, in contact with my cattle. I at once gave notice to the Field Cornet, that I held them liable for any loss I might suffer. The Field Cornet, a Boer friend of theirs, took no notice of my complaint, and the Schoeman's knew that nothing could be done to them. Nine days after this, three of my cattle developed Pleura-Pneumonia (Lung-sickness) and I lost three hundred and seventeen large oxen and cows and seventy calves, and got not a penny of compensation. It was almost impossible to farm stock next to Transvaal Boers, they intentionally allowed their animals to graze their neighbours' veld to spare their own; and persistently refused to pay half-costs of erecting fences to keep their stock out. There was a fair amount of game on my block of bushveld farms, Koodoo, Pallah, Haartebeest, Blue Wilde- 
beest, besides small buck and I took pains to preserve them, but these Boers along Sand River never ceased to poach my farms during our absence and now only a few Koodoo and Ostriches are left. I had enclosed about eight thousand acres of the best game veld but they cut the fences, rode in and shot whatever they could. On more than one occasion my farms were set fire to, and burnt completely out, because I refused to give free grazing and $I$ had to take all my own stock away in consequence.

The fencing of farms with posts and wire is of recent date, I had to fence with stone walls, of which some miles remain on "The Willows" to this day. My neighbour, Matthias de Beer, came to me in a rage one day and said that the building of a wall along $m y$ boundary was an unfriendly act, as it would keep his cattle out of the best grazing along the river in Koodoo camp (my farm), and in consequence he would not speak to me for some time. Even now, (in 1911), I have erected on various properties altogether over two hundred miles of boundary fences, and subdivision fences, and have hardly ever been able to get my Boer neighbours to share the cost; although these fences are of iron and permanent and they have beneficial use of them. Payment of joint boundary fencing should be made compulsory in most districts; (such legislation has now been provided vide Act 17/1912), as the enterprising landowner has to work for the indolent one. About 1866, I asked Izaak Holtshuizen to catch some young ostriches for me, promising him $£ 5$ cash for six months chicks. He brought forty-four birds, and I had to pay him what was a large sum in those days (£220). It was the first venture of its kind in the country, no one knew anything about feeding or plucking, nesting or rearing ; and although the birds grew to be a very large 
size, much bigger than the present domesticated bird in the Cape Colony, the want of knowledge on my part made the attempt at farming wild ostriches at that early date unsuccessful. Some of them became very savage. One day a large cock ran at mother and her sister, and would have killed them, had I not happened to look out of my office window and seen the danger they were in. I had no time to look for any weapon, so took off my coat as I ran, threw it over the bird's head, pushed the two ladies through a pole gate, and just had time to vault over it myself, when he rushed at me, and drove his toe into the pole an inch or two behind me, this caused a strained feeling, so I fetched a gun and shot him. He had previously ripped open some working oxen, and chased Kaffirs all over the place. The birds wandered to some distance, and neighbours shot them for their feathers, pretending to think they were wild birds. So ended my first ostrich farming venture.

I used to send my cattle for winter grazing to the bush-veld farm I owned near the Salt Pan, this pan was Government property, and the Boers and their families came long distances to collect and clean the large salt crystals for preserving meat, butter, etc. It is a most picturesque crater of an extinct volcano, the cone rises from the bush-covered plain to some height, and is noticeable for many miles. The Salt Pan itself lies at the bottom of the old crater, about 700 feet down and is covered by a crust of block salt, some feet thick in parts, on this, after rain, fresh crystals form and are collected. Of late years the pan has been neglected and less and inferior salts and soda obtained. I. W. Henshall, representing Alexander McKorkindale (of New Scotland fame), erected evaporating pans ; but owing to wars, etc., they were abandoned. Some Johannes- 
burg company erected expensive works again, but during the war of 1900 these were also abandoned. Some machinery is there still. It is curious that several rather severe earthquake shocks have passed over the pan during the time I have known it. We had some pleasant picnic parties there from Pretoria in the early days, when the little European community were like one family. Since then, the pan has been much destroyed by lessees cutting down most of the big trees, and generally injuring the property. There were many beautiful birds, green parroquets, green sprews, blue jays, honeybirds and much game, but the Kaffirs from the kraals near by have destroyed all animal life. These farms are 35 miles from "The Willows," and I used to start after midnight, ride down and count up the cattle at sunrise. This kept the herdsmen on the alert, my chief trouble was that of the Boer neighbours setting fire to the dry winter grass, when a strong wind was blowing on to my farm. One old fellow, Wolmarans, was the worst culprit, and was caught in the act more than once. Old Jan Hennings and Rasmus Erasmus, both told me that my only chance was to burn old Wolmarans out once or twice, and then it would stop, but this I would not do. The country all about this Salt Pan I believe to be tin-bearing, the formation being similar to that in Kameel Port and Enkeldoorn, and gold has been found in the vicinity. It lies also in the line of diamond pipes of the Premier and Kaalfontein Mines; which are visible from the top of the Salt Pan kopje, to the east.

On August 4th, 1869, I sowed gum tree seeds which are to-day the big trees in the large plantations. On August 2nd, I built the wagon house on "The Willows" myself, my first and last attempt at brick laying and carpentry. In those days we had 
to be versatile, one day framing laws, another farming, one day on a Government commission, the next planting trees, one day sitting in the Volkstraad, the next inoculating cattle, one day prospecting for minerals, then painting, carpentry, shoemaking, building. travelling all over the conntry on various quests. Truly, a varied, curious life.

During these years our home "The Willows" was a rendezvous for the European people in Pretoria, we were seldom without guests.

On June 7th, 1869, my dear old father died in Pretoria, he had suffered much loss and had had many worries in his later years. 


\section{CHAPTER XXII.}

\section{NATIVE WARS AND UNREST.}

Ever since the days of Lord Glenelg, when (after the exhausting frontier wars) he reversed the policy of the military commander, and the Colonial authorities, and re-instated the hostile tribes on land within the Cape Colony, South Africa has been subjected to a policy of expediency, to satisfy the so-called negrophile sentiment, represented in England by the Exeter Hall party, and also on the part of the Whigs or so-called Liberals, to capture seats in the British Parliament, rather than to establish a continuous, consistent, practical basis of policy, in dealing with the native tribes, in the several colonies and states. The Exeter Hall would-be philanthropists-influenced largely by reports of some missionaries who take an unpractical and onesided view of the problem - and of cranks, who make it their hobby to write harrowing tales of the "dreadful treatment that the innocent native receives under the rule of the barbarous and uncivilised white colonists," are really the natives' worse enemies. They teach them equality before they are in a sufficiently advanced stage to fully appreciate their real position, and the result is trouble and punishment; which could have been avoided, if they had been left to settle their differences without outside influence.

The Basutos during the sixties were causing unrest on the Free State border, thieving stock from farmers, and spoiling for trouble with the Free State Boers, which culminated in war in 1866 . The mount- 
ed Basutos at the commencement made long distance raids, killing and burning. One raiding party went as far as where Standerton now is; and killed Adrian Stander's sons in the door of their house; another party raided as far as Brandfort, looting and burning en route. The Free State President, John Brand, afterwards Sir Christoffel Brand, had to face a barbarous enemy with a force of burghers, requisitioned from a sparsely populated farming area, indifferently armed and ill-found in ammunition. Under these adverse conditions, the "foreign enlistment act" was enforced in the Cape Colony, forbidding British subjects to take part in the war; and the supply of ammunition for the Free State forces was made as difficult as possible.

The family of Piet Pretorious was murdered at Elands Kop (on top of the Drakensberg) on the Natal border, by a Basuto "Impi," when on their way to raid the upper districts of Natal. The Basutos found the Pretorius' outspanned, and told them that they had no quarrel with the Transvaal Boers; so put them off their guard, and when they put down their arms, rushed at them and murdered them, all except Mrs. Jan Pretorious and her two children, whom they stripped naked, and she had to walk into Harrismith (about 15 miles) leaving her husband, father and brothers dead on the veld. How she survived such an ordeal is a wonder, poor woman. This Pretorius family were near relations of President Pretorius. A Transvaal Commando was sent to assist John Brand, but after a severe attack on the laager by Slangaal, and friction between their leaders and the Free State authorities, (about the apportioning of farms when the war should be concluded) this commando returned to the Transvaal, and left the Free Staters at a great 
disadvantage to fight it out alone; they were short of money, of ammunition, and of men to relieve those at the front. The country had been raided in all directions and the farmers impoverished, but $\mathrm{Mr}$. John Brand's patience and courage prevailed, and the Basutos were conquered for the first time in their history.

After the murder of the Pretorius family, the looting of the wagons, and the raid into Natal, the Natal authorities claimed indemnity from the Basutos for these outrages, committed in British Territory, but I am not aware that anything was done or people compensated for their loss. After great hardships endured by the Free State forces, during a prolonged struggle, the Basutos were conquered and Basutoland invaded, when the Basutos at once appeale for protection to Sir Philip Wodehouse, Governor of the Cape Colony. He proclaimed the Basutos as British subjects, forbade the Free State Forces to take any further action in the field, or to shoot one more Basuto, and claimed the right to settle the boundry between the Free State and Basutoland ; allotting the Free State a strip known as the "Conquered Territory". Had he not taken this course, the Basuto tribe would have been broken up, and they would have been removed from their mountain fastnesses and distributed elsewhere.

The Basutos, after their first murderous raids, (while the Boers were unprepared) soon got tired of fighting in the open and took to their vast mountain strongholds; but were prevented from cultivating their lands, and having lost most of their cattle, (which they had not sent to East Griqualand); they were reduced to semi-starvation. Boers from the Transvaal took in loads of kaffir corn, and got as many as thirty horses for thirty bags. I also sent 
in two loads as soon as peace was proclaimed. The result of Sir Philip Wodehouse's interference was shown a few years later, when, owing to Sir Gordon Sprigg's disarmament proclamation, these same Basutos, nominally British subjects, waged a war with the Cape Colony, which cost millions. It largely increased the Colony's debt; but nothing was done to disarm or conquer the tribe. This war called the Morosi War was brought about as follows :-

In the early days of the diamond fields the Griqualand West government (under Sir Richard Southey,) allowed natives working on the mines to be paid for their work, in guns, as an inducement to labour. Their chiefs ordered them to accept guns in preference to money. The consequence was that Langalibalele in Natal, Sekukuni in Eastern Transvaal and other tribes, and the Basutos acquired arms wholesale, mostly cheap Birmingham "gas pipes" (of little value it is true), but also some efficient guns and ammunition. This was done in a newly-annexed British colony, while in all other adjoining colonies the law prohibited natives from possessing fire arms. The first consequence of this inconsistent and nefarious policy was that, when Langalibaleli was called upon to give an account of his arms it led to friction; then to rebellion, and the deportation of the chief and the ruin of his tribe. Colonel Durnford, the same man who was to blame later on for the disaster at Isandhlwana (having disregarded warnings), was caught in a pass in the Drakensberg, and several young Natalians were killed by Langalibaleli's men. Then there was the trouble with Sekukuni when the Boer commando under President Burgers was defeated, and after the annexation the expedition under Colonel Rowlands was such a fiasco. Sekukuni 
was at last reduced by volunteers, Swazies and Imperial Troops under Sir Garnet Wolseley. Then when the Cape Government, (Sir Gordon Sprigg as premier) demanded the disarmament of the frontier natives and Basutos, the Colonial forces failed in the field and retired, and the Colony had to face a heavy debt, besides loss of prestige. All these disasters were the outcome of a want of a rational and continuous policy in dealing with the native races, and the interference of statesmen, who could not understand the conditions obtaining six thousand miles away; and whose sympathies were frequently more with the black races than with the struggling Colonists in South Africa. During the Basuto war of 1866, I had one or two disagreeable experiences. I was on my way from to Pretoria on horseback, and on reaching Dodd's Hotel on the Sand Spruit (under the Drakensberg), I found the place burnt down and quite deserted-the Basutos having raided the district. I got a Zulu who was loafing round, to cut me some grass for my tired horse, waited there to rest him for some time, and then rode on towards Harrismith. After passing the Drakensberg I kept well on the alert but felt anxious, as my horse was tired, and any Basutos I came in sight of could catch me. When near Wilge River a Basuto commando passed to the west of Rensburg's Kop, while I kept on the road to the right. If I had been half an hour later they would have had me, where they came into the main road at Elands Kop. I heard of their movements when I got into Harrismith from Commandant Piet Dreyer, who had just returned from a patrol. I was unarmed, the country was full of Basuto raiders, and I had to ride alone to Pretoria; so after much pleading, Dreyer sold me the only revolver obtainable. He (poor fellow), while on patrol, was ambushed soon after this and killed. 
I kept the revolver as a memento for many years. I think it was taken when "The Willows" was looted in the Boer War of 1880 . I then bought the best riding horse I could get in Harrismith, and went to bed, instructing the hotel keeper to wake me at sundown. I started for the open country rather too soon, for when I reached Marais' farm, half way to Mill River, it was still light, so I put my horse into a ruined house and lay down by him to rest. While dozing, I was awakened by my horse fretting and the trampling of hoofs outside. I jumped up, expecting to see Basutos, and, looking cautiously through a broken window, saw to my relief that it was a troop of blesbok galloping past. I waited in those ruins until it was quite dark and then started on. The moon was rising as I got near Mill River, and, as I topped the rise, I saw the fires of a considerable commando in Solomon Maritz's stock kraal and homestead, and when nearer could hear kaffirs shouting and talking. Fortunately, I knew the country well, and leaving the road, made for the deep grassy banks of the river some distance above the drift. I led my horse along the bank, as a long deep pool prevented my crossing, until I came to a ledge of slippery rocks a couple of hundred yards above the drift, I then mounted and rode cautiously over the slippery stones. When half way across, the moon came out and two kaffirs, who were getting water in the wagon drift, saw me and shouted "there is a white man," and raised the camp. There was a commotion at once; but I knew that their tired horses were Igrazing and knee-haltered, and unless my horse fell, I would have a good start; so was careful not to hurry him over the slippery rocks. When once on dry ground I rode hard, leaving the road, which I knew the Basutos would take, keeping to the small table-topped hill, and soon got into the 
broken ground towards Cornelius River. The Basutos evidently soon gave up the chase, as after a time, I could not hear them; but for fear of a trap, I kept on through the veld away from the road in the dim moonlight. It was a cloudy night, and I had to return to the road to cross Cornelius River. After reconnoitreing I saw or heard nothing, so ventured to cross and rode on to Field Cornet Lodewyk Oortendaal's farm, found the place recently burned and deserted; so I kept off the road to the back of the hill, tied my splendid horse "Tromp" to my wrist (as I was too sleepy to risk holding him), and each time I woke I shifted in the damp green grass, to allow him to graze a little. Before daylight I again pushed on, reaching Drosky's place over the Vaal River, at midnight, about eighty miles ride. In this war, Moshesh's sons, (who had been educated at a Cape Town Native College), were said to be the most active enemies of the white man.

My father and one Van Saarveld, while travelling to Bloemfontein, were nearly caught at Kromellenboog; fortunately, Van Saarveld, an old campaigner, had hid the cart and horses in a deep gulley, when soon after, about sunset, a Basuto commando, camped about a mile from them. They had to remain in hiding till after sunrise next morning, when the Kaffirs rode off towards Basutoland.

I always considered that the behaviour of Governor Wodehouse was disgraceful, after all the Boers had suffered both before and during the long and tiring war which had ruined their country.

Since the Basutos were again taken over by the Imperial Government (after the fiasco of the SpriggMerriman Government), they have been at peace, living their own life under their chiefs, subject only 
to the supervision of a British Resident, but no laws ean be carried out if repugnant to them; and with the natural increase of the population, an agrarian trouble may at any time develop, as the habitable portion of their mountainous country is being tramped out, becoming crowded and too small for them and their stock. Before the last Boer war General Piet Joubert said to me " the Basutos will prove the factor which will bring the Englishman and Boer together in self defence." I have had enough of war in South Africa, and devoutly hope that the day is far distant when a serious native uprising will be required to cement the union of the white races in South Africa, which, since Joubert's has been accomplished politically.

I have lived in South Africa, since 1850 with interludes of travel in Europe, Asia, America and Australasia, but I shall always have a soft corner in my heart for the trustful, patient, docile native, both Zulu and Bechuana, or Bantu of the Transvaal. I have gone through anxious times with them, many have been with me for about forty years, many have grown up on my properties, and on the whole I have found them infinitely pleasanter to get on with than the lower class of white people. It is only when they get spoiled and ruined by contact with the lower stratum of civilisation; or have been taught indiscreetly by ill-advised, but probably wellmeaning missionaries, that they become unreliable, impudent and often hateful. I have an affection for my old natives. I know their weaknesses and their good qualities. My difficulty is to get anyone who will take the trouble to understand them and treat them sympathetically but with firmness, justice and judgment. 
Since the war, when they lost most of their property, and had their villages burnt, they appear to have lost heart and self-respect, and they have taken to beer drinking to excess. They complain that their women spend all that they make in the Indian shops on dress and trumpery, that many become immoral, and will not work as of yore. One cannot but feel sorry for the poor people in this unfortunate transition state, which they cannot avoid, in their contact with European civilisation. The trouble at present is that the old men, women and children remain on the farms, whilst most of the young, able-bodied men go to the Premier Mines, the Rand Gold Mines, and the shops in Pretoria, where they get high wages and learn bad ways. They can grow thousands of bushels of maize, millet, kaffir-corn, etc., and could be infinitely happier than the poorer classes in England, or any part of Europe. Sometimes the locusts destroy crops either wholly or partially. The natives catch and bag them before sunrise, and boil them in large pots (when they turn red like shrimps), dry them, and pound them into meal, which is valued at from 15/- to 20/- a three bushel bag, and they consider it twice as nourishing as maize or kaffir corn meal. Animals are also fed on this. 


\section{CHAPTER XXIII.}

\section{DISCOVERY OF DIAMOND FIELDS AND}

EARLY KIMBERLEY DAYS.

In 1870, Mary, Fred and I went to Aliwal North, with a load of ivory and a large drove of fat oxen which I sold to Richard Harvey and Graham, partly for cash and partly in exchange for sheep, as I intended to start sheep farming. Money was very scarce, and I took sheep in part payment at $3 / 6$ to $4 /$ - for good merino ewes, and I bought sheep on the way home as low as 2/6. At this time I heard of the discovery of diamonds on the lower Vaal River, so I hurried back to "The Willows," sold the sheep, packed some wagons with provisions, and went to the Diamond Fields to try my luck. It was an exceptionally wet season, and all the rivers were full. Near Loskop the oxen got lost. After much riding about in the rain I found them on an island, surrounded by the swollen spruit; but I could not find the native herd anywhere and concluded that he had run away. The poor fellow must have been drowned as he never returned to his kraal.

We could not cross the Vaal River at Lindeque's Drift, but found that a Boer had a pontoon boat a little lower down, he said that he could ferry our two wagons across. $\mathrm{He}$ had a Kaffir caulking the boat with "pot clay"; when I said that it did not look very safe, he said that he had taken numbers of wagons over with the boat in that condition. I put some ivory in for the first trip, and took off my clothes and went into the boat. We had 
not gone more than twenty yards when the pot clay dropped out, and the boat filled; we just managed to reach the bank when she sank. The rascal of a fellow wanted me to pay in advance, knowing that the rotten boat could not get over. We had to trek all down the Vaal River until we got to the Pont, (on the Potchefstroom-Kroonstad Road), when I swam the oxen across, and put the wagons, etc., on the pont.

P. J. Marais joined me in some of our ventures; Ted and Fred and young Preller, and others worked claims with us. We did not make money on these river diggings, some of our little companies made a little, others lost. The first day at Hebron while I was showing one of my Kaffirs how to mark out a claim, I picked out a nice white river stone, this I had afterwards set in a brooch, a St. George's Cross made of Pilgrim's Rest gold for mother, which she still has. At this time, the De Beers and New Rush dry diggings were discovered and we pegged out claims there. There were no houses, only tents, so I got a boat on the Vaal River, cut poles on an island, rowed them to the Free State side, transported them to De Beers, where I had a small wattle and daub house put up, with one glass window, which was the admiration and envy of my friends, and we had pleasant little gatherings in it.

The work on the diamond fields in the early seventies was very hard. I was up at dawn every morning, had an early scratch breakfast and was at the claims at sunrise. The claims were cut down on each side of the narrow roadways; carts, mules and oxen fell down them frequently, and people were often killed or injured. Before I left, the roads between the claims were narrow and the claims getting deeper. One day, when in the claim, in- 
specting the work, some ground fell on me, I looked up and saw two oxen coming over the edge. I had just time to warn the men and get flat against an overhanging wall, when the pole of the cart broke, the two big oxen came crashing down, and were killed a yard from me. Another time, a bucket of soil got loose at the top and killed one of my boys. Yet another time a cart and a pair of mules fell into a claim. Accidents were of daily occurrence.

While I was experimenting with a bucket of diamond soil, running it from the gear head to the sorting table, a big Boer was scrambling up the debris heap, when the bucket caught him on the head and knocked him flat, when he recovered he came at me with a knife, in a towering rage, and would have done me some damage, had not Ward, the Mine Inspector, come to my aid. Ward had his thigh broken shortly afterwards by some Boers, while carrying out his duties on the mines. Marais and I were negotiating with old De Beer for the purchase of the entire farm on which De Beer's mine is situated, we had as good as settled the business, when De Beer's son-in-law, a Hollander, came to our camp in the evening and wanted to know what he was to get from us if he allowed the purchase to go through? We thought it a case of blackmailing as he had no rights, and we did not think he could influence old De Beer. The next morning De Beer refused to sign the deed of sale, and a little later Dunell, Ebden \& Co., bought the property for much more than we were to give for it. As it was, we owned a large area of the De Beers mine, but it was not until later considered very valuable as many of the larger stones were yellow. We found in the early days a yellow stone for which the local buyers offered one thousand five hundred pounds cash; but we decided to send it 
to Europe to have it cut, after many expenses and loss of time, eventually we got only eight hundred pounds for it. I also held some claims in the new rush or Colesberg Kopje (Kimberley mine).

Marais and I had to make several trips to and fro between Pretoria and the fields, we much enjoyed the free life on the road. One trip we slept out in the patch of vaal-bosch trees, where years afterwards Delarey's commando ambushed Lord Methuen's convoy under Major Anderson. It was in the winter and bitterly cold, we started next morning at dawn, it being Marais' turn to drive. After a short time he asked me to take the reins while he lit his pipe, but when I offered him the reins back he refused to take them. I threatened to upset the cart, but being a man of far-reaching knowledge, he said, "No you won't, it is your own buggy." True it was a nice new trap and I didn't, but I thought over the matter. Late at night we arrived near Potchefstroom, and when we came to the first big water furrow, I got out to find a crossing; I found a small foot bridge, and called out to him to go down the furrow till he came to a crossing, in the meantime I walked to the hotel and as he did not turn up, had supper and went to bed, telling the landlord to send a man to look for Marais, but when he came, not to tell him which was my room. They found him wandering among the Potchefstroom water furrows, in a most unreasonable temper and wanting to know where I was! Next morning I had to explain, with much sorrow, that I found it due to myself, and as a wholesome lesson for his future guidance, to pay him off for his behaviour in the cold early morning. I will not repeat his language, but no blood was shed. When we first went to Hebron, a native chief Iantye set up a claim (backed by certain adventurers), to 
the diamond fields north of the Vaal River. President Pretorius was very weak, and had actually taken out a digger's licence from one calling himself President Parker. Marais and I went to President Pretorius and pointed out that he was giving himself and the Transvaal away, and that it was his duty to assert his authority, he was slow to grasp the situation, weak and uncertain, and the end of it was the "Keate Award," giving the case against the Tranvaal; this was the prime cause of the poor President's downfall. There were some native scares and some people bolted about to avoid the savages, but I refused to move our camp and nothing happened to us. This self styled President Parker confiscated my two loads of meal, etc., because I had not paid some dues he claimed on something, but old Mr. R. W. Murray, who had some position at that time, got me off. If Parker had kept my stuff I should have been in a fix to feed my people, as food was scarce, having to be brought hundreds of miles by ox wagon. Paddy Rolleston and some Natal men were on the river near us, Cecil Rhodes afterwards joined them I think at the New Rush or the Colesberg Kopje, now the famous Kimberley mine. Rhodes was a poor and delicate lad with nothing but his brains and energy for capital. Once on a voyage to England, when he used to discuss with me the possibilities of the interior, now Rhodesia, he said to me, "If you with your knowledge, and I with my ideas, had known each other better in the early Kimberley days, we might have done a great deal of useful work for South Africa." I answered "Yes, but I think you are doing quite enough, and I am a quietgoing man with a family, and am content with a competence and less worry." $\mathrm{He}$ was certainly a big hearted, broad-minded man, with nothing small or mean in his character, and whatever mistakes he 
may have made, the insignificant creatures who calumniate him, are not worthy to tie his shoe strings.

I greatly admired his breadth of view, his persistency and courage and open handedness, although I could not pretend to keep pace with him; he was a man who only appears in a country once in a generation. It is not likely that a second Rhodes will visit South Africa or have the opportunities the diamond mines offered, of carrying out his grand programme of Imperial expansion in the "Dark Continent."

The pertinacity of Rhodes and his far sightednese were characteristic, as also his contempt for money except as a means to an end. How many men we still have with us who would have been less missed in these critical times in South Africa. I did not stay long on the diamond fields, the life did not suit me. Any money I made I sent to Natal to pay off in coin some accounts that I owed and which $I$ would not pay in Transvaal Notes worth only $2 / 6$ in the $£$ although they had been made legal tender; and Boers had taken advantage of that to pay long standing accounts they owed me in this worthless paper currency. When mother and Arthur both got ill, I took them back to "The Willows" and disposed of my interests in the diamond fields.. One valuable claim in the middle of Kimberley Mine I left Lexy Maclean to work but he never attended to it, and sold it for a fraction of its value.

Jew diamond buyers called ("Kopje Wallopers") went the rounds of the sorting tables daily buying small parcels of stones. Most of them developed into merchants, magnates and millionaires, many 
of whom added to their legitimate business, that of Illicit Diamond Buying, and encouraged natives and low whites to do the stealing, and take the risks, while they piled up wealth in safety. Sunday was a great day among the kaffirs, troops of them went a short distance from De Beers and fastened the Birmingham cheap ("gaspipes") they had bought to the large thorn trees which then covered the ground, tied long strings to the triggers and fired them off to see if they were safe to use, as many had burst and injured the owners.

I probably missed a great fortune by selling out when I did, but anyhow, mother and Arthur and I still have sunshine, health, friends and families, which are of better value than six feet of diamondiferous soil in Griqualand West. How many poor fellows who went there full of hope and energy failed to get their "castle in Spain" but left their bones there, while some amassed wealth, but did not appear much the happier. I for one am truly grateful that all happened for the best. 


\section{CHAPTER XXIV.}

\section{EARLY GOLD DISCOVERIES, LEYDENBERG AND ELSEWHERE.}

Shortly after my return from the diamond fields in 1872 Piet Marais, Charles Becker and A. Gusman came to "The Willows," and asked me to join them in a venture in Lydenberg, where gold had been found in small quantities. I was intending to visit Europe at the time and refused. Marais said, unless I joined them he would have nothing to do with it, and between them they persuaded me to go. I supplied horses. etc., and we passed through Lydenberg, stayed with the splendid old pioneer Izaak Breitenbach, and got Piet de Villiers to show us the way from there, past Krugers Post over the mountains to the Blyde River.

While prospecting, I discovered what I was convinced were ancient workings, and found a little gold in several places. The others did not do much. Marais and I decided to buy the farms "Ponies Krantz" and "Drie Kop" afterwards famous as "Pilgrims Rest". We returned to Pretoria and at once started off again for Rustenburg; bought the two farms outright for cash from the owners, who lived there. Nothing much happened for some time, but shortly afterwards, while I was sitting in the Durban Club, a friend of mine came to tell me that rich gold had been found on our farms; and that several hundred diggers were ground-sluicing for "alluvial". I returned at once to Pretoria, persuaded President Burgers and Judge Buchanan, (then Attorney-General) to go with us, see the diggers, and 
arrange proceedings. I employed myself in collecting all the information I could from the works on the Mining Laws of Australia, New Zealand and California,- which I had sent for some time previously, - and drafted a set of laws, which I considered would suit South Africa. The AttorneyGeneral did not like me, having usurped his place, but as there were no Transvaal Mining Laws, and he had made no attempt to frame any, Mr. Burgers agreed that he would discuss the laws that I had drawn up, clause for clause, and with a few slight alterations, the Law as drafted by me, became the Transvaal Gold Law. It rained incessantly that season, and the rivers were high. We were warned on the way up that the diggers were unruly, and had threatened to assault Mr. Burgers if he came to the diggings to interfere with them, so, on reaching the swollen Blyde River a camp was formed and a council of war was held. Some tried to persuade the President to return to Pretoria and not take any risks, but I pointed out how completely such a retreat would destroy the prestige of the Government, offered to swim the river and interview the diggers in the morning, and I prevailed. In the morning some hundreds of diggers assembled on the opposite bank. I swam across in a "state of nature," introduced myself as the proprietor of the property, said that I intended to make reasonable terms with them, and that President Burgers who was on the other side, wished to see them and discuss the matter. The good enough fellows cheered me, said they would treat Mr. Burgers with respect, and at my request sent to the Mining Camp for a long rope to assist us through the rushing stream, which was slowly going down. Mr. Burgers said "my dear Struben, I can't swim," but I promised not to let him drown-I put stones in the wagon to prevent it 
being turned over by the current-put the President on the "cartel" (slung high) and also the light articles, I swam through with the end of the long rope tied to the end of the trek-touw, and then went into the stream below the oxen to keep them up stream, while the diggers walked away with the rope, and although the water was half way up the wagon, we got over safely, receiving quite an ovation from the good-natured diggers. We had palavers with their leading men, a dinner and speeches, discussed the Law as drafted, made one or two slight amendments, the diggers appointed a Committee and Chairman to look after their interests. We appointed an American, Mansfield, to represent us as proprietors, and stayed among the miners for a considerable time, riding round the country and inspecting mining operations. $\mathbf{P}$. Marais who was one of our party took very little interest in mining, and did not like the discomfort of camping in the wet weather, so got himself taken over the river and the mountains to Tom Mullers'. Next day he wrote me a pitiful tale of woe. The room they gave him was "alive" with "Norfolk Howards" so he moved into a tented wagon which was worse, he was reduced to three meals a day, of buttermilk and peaches. He was depressed in spirits accordingly. Mr. Burgers and I discussed the situation and wrote to him that we deeply sympathised with him, and drank his health and return to a less blasphemous frame of mind, but as candid friends, told him that buttermilk and peaches were excellent purifiers of heated blood, and that "B flats" taught mortals not to be proud. Heart-rending letters were sent daily, and as he was between two swollen rivers Mr. Burgers and I consoled ourselves on the receipt of each letter with a bottle of Hock and fervent hopes that his troubles would soon be ended. 
In a few days, the rain having ceased, and the rivers somewhat subsided, the diggers again helped us to cross the Blyde. Gray Barber lent us his span of oxen to assist us out of the steep, slippery mountain. I had been so long in the cold river, helping the wagon through, that I was laid up with lumbago. Much "alluvial" gold was taken out of the Pilgrims Rest Creek, and there were about fifteen thousand diggers on the property, but as we could not get satisfactory terms, arranged with the Government and the diggers to sell the entire property to a Port Elizabeth syndicate. Subsequently war broke out with Sekukuni, the diggings were raided, and the diggers (through Magistrate Cooper,) asked for British protection. Then in 1877 the annexation took place, and for years the Lydenburg gold mining areas were neglected. The discovery by my brother Fred and myself of the Witwatersrand gold fields, diverted the attention of the mining and speculative public. Lydenburg although a valuable gold-bearing district, is only slowly regaining popularity. 


\section{CHAPTER XXV.}

\section{SEKUKUNI WAR, AND FALL OF PRESIDENT BURGERS.}

During the session of the Volksraad in 1876 , letters were read from officials and others complaining of the warlike attitude of Sekukuni, and his subordinate "Johannes", details of which I will not enlarge upon. A motion was brought forward declaring that the action of the Bapedi tribe made it imperative that war should be declared, and a burgher commando called out. Commandant General Piet Joubert, member for Wakkerstroom, and I, (member for the Pretoria district) voted against the resolution, on the ground that the Republic was not then prepared to take the field; that there was no money in the Treasury; and we also knew that a section of the people were disaffected; that $\mathrm{Mr}$. Burgers, who intended to take command, knew nothing of the Boer mode of fighting or of Kaffir warfare, and we feared disaster. Mr. Burgers, full of confidence, gained the ear of the Raad, and the resolution to declare war was passed, with our two dissentient votes, which were recorded. When I saw that war was inevitable, I begged President Burgers not to take the responsibility of command, asking him to appoint Mr. Paul Kruger, who knew more about native warfare, who would also probably work against him in his absence, and I pointed out that if the Boer forces met with a reverse, he (President Burgers) would have the full blame. The evening before he started he sent a messenger on horseback 
to "The Willows" to ask me to see him. I went into town and argued till midnight all the points with him, till at last he decided not to go, but next day I heard that he had started, Swart the Secretary to the Government told me that the President had instructed him to do the financing, but he had no money available. I had warned the President that Solomon Prinsloo and his following intended to give him trouble, but he said that he felt "his star was in the ascendant," that he would come out of the war with safety, etc. An attack on Mathila's Kop on a Sunday was the first opportunity taken by Prinsloo to denounce Mr. Burgers, and start a spirit of disaffection in the laager; and again after the failure of the attack on the mountain, he declaimed against the president and his methods, and the burghers were only too glad to listen. With a cry of "Huis toe" ("Home,") the commando broke up, Mr. Burgers being left to find his way back to Pretoria as best he could. My brother Fred was appointed the President's aide-de-camp during this disastrous campaign. Volunteers were placed in forts near Sekukuni, to keep him in check; and remained there until Sekukuni was finally subdued by Sir Garnet Wolseley, in 1878-9. On the re-assembling of the Volksraad after this fiasco of Mr. Burgers, I was appointed by the Government and the Raad to investigate the causes of the failure of the commando, and I am afraid made some enemies on account of my plain speaking. In cross examination of witnesses it transpired that a German, Von Schlickman, who had been conspicuous for bravery on every occasion, had begged Mr. Burgers' permission to turn the guns on Solomon Prinsloo and his party, and destroy them; as they were rebels during war time, but Mr. Burgers would not let him. When Von Schlickman was called upon to make a statement he told me (in Com- 
mittee), that he intended to shoot Prinsloo and repeated it before the full Raad, pointing to Prinsloo as a traitor. I also had to settle a dispute between Stephanus Roos and Colonel Ignatius Ferreria, and there were many painful episodes that I will not mention here. Stephanus Roos led the storming party on Majuba in 1880, and was shot on Mapoch's Hill, on the anniversary of the day on which Sir George Colley was shot on Majuba. There was a superstitious feeling among the Rustenberg Boers where he lived about it. The church bells were rung and much said on the strange coincidence. $\mathrm{Mr}$. Burgers had been promised by the Boers at Sekukuni's that they would pay a special war tax, to pay for the volunteers who were left behind. As member for Pretoria district, I held several meetings, largely attended, and begged them to pay the $£ 10$ tax per farm as imposed: I was told, that my statement that there was danger of their losing their country if they would neither fight nor pay did not frighten them, and many said that they did not trust their Government, some said they preferred the British rule to the unrest and bankruptcy that they had endured for so long. When Sir Theophilus Shepstone afterwards annexed the Transvaal, this £10 tax (which had been paid by only a few), was remitted.

One of the causes of discontent during Mr. Burgers' Presidency was the imposition of a railway tax of $30 /-$ on the farms, while no railway was being built. Mr. Burgers had gone to Europe, authorized to raise a loan for the purpose of constructing a railway from Pretoria to Delagoa Bay. Mr. Hall was appointed to survey the line, which he carried through Swaziland, on to to the plateau near Klipstaple. This route was after the annexation again surveyed by Mr. Farrell, but subsequently; under 
Mr. Kruger it was changed to the present one via Waterval-onder, partly because Mr. Kruger did not want it to go through Swaziland, and partly to serve certain private interests. Major Machado afterwards Governor of Mozambique, surveyed it but did not consider it the best route. I was appointed by unanimous votes of the Volksraad in 1876, as the first Director of the Delagoa Bay Railway and representative of the Transvaal. Mr. George Piggott Moody, afterwards Surveyor-General representing Portugal, was also a director. Mr. Burgers went to Holland to negotiate the loan, and to Belgium to purchase rolling-stock, rails, etc. The loan in Holland was only partially taken up, Mr. Burgers in the meantime ordered a state coach and some rails and rolling stock in Louvain, but had not a penny to turn a sod or buy a wheelbarrow, and I as director, had the unpleasant duty of explaining the financial situation, and the unbusinesslike way in which the loan, etc., had been conducted, including the excessive commission charged by the people in Holland who assisted Mr. Burgers. The president was in an awkward dilemma, but no more money could be got on loan, the Hollanders evidently distrusting the Transvaal Government; for as soon as the Annexation was known in Amsterdam, the people at once communicated with London, offering to complete or oversubscribe the loan. Their offer was not entertained by the British authorities. Mr. Burgers was authorised by the Raad to borrow $£ 300,000$; he only obtained $£ 14,000$, much of which went in commissions and donations to Hollanders and Belgians. A very large safe he bought to put surplus cash in fell overboard while being landed, and lay at the bottom of the sea in Delagoa Bay. Hollander love of the Transvaal rose to the highest level when they obtained valuable concessions for the mint, railways, the National 
Bank and other monopolies authorised by the Volksraad. Mr. Burgers brought from Holland Mr. Von Gorkum as Minister of Education and Dr. Jorissen (who had been a parson on an island in the Zuyder Zee), as head of the schools. Some Hollanders wrote that they were not orthodox, and an agitation was started, led by Daniel Taljaard, to prevent their appointment to the Raad. Mr. Burgers appealed to me, and I pointed out that as the Raad had authorised their engagement they must be given a chance, and could not be dismissed on inadequate evidence of unsuitability. They were retained, and Jorissen became a prominent politician during the annexation period. Mortals cannot foresee events!

At this time, besides my own private work, I had mueh to do. I was president of a land commission, which necessitated visiting various parts of the country, to settle land disputes, which took up much time. I was on several committees on the Raad, finance committee, Director of Railways, a special commission to enquire into official salaries and working of offices, etc., besides the daily attendance in the Raad as Member for Pretoria District.

On May 10th, 1876, General Piet Joubert, Jacobus Esterhuizen and myself were appointed by the Volksraad to draft native laws, and more especially a "Plakkets Wet" that is a Squatter's Law. At the time I pointed out that it would be difficult to enforce this law for various reasons, but $I$ was in a minority, and the law was passed; it has since proved to be in-operative. It has never been honestly enforced; some people were harassed and threatened; while Field-Cornets and other officials, instead of the five families allowed by the law, kept as many as they liked, drew rents from some, and obtained their labour from others. Many Boers 
gave over valuable farms to natives to cultivate on half shares, doing no work themselves, the consequence will be that the native will become an intelligent, energetic farmer, and the the Boer a loafer. Under the Squatter's Law five householders are of little or no use to furnish labour for the landowner, and a difficulty is how to break up families, when, owing to natural increase, they are in excess of the five families allowed on one farm. On the other hand, the locating (by large land speculating companies) of hundreds of natives for the purpose of Kaffir farming cannot be allowed, but it is too big a question to be discussed at length in these notes. Under the Union, the whole native question will come under review, and the systems obtaining in the various provinces will be brought into line as to land tenure, the franchise and the position of native women, should the franchise be given to white women.

During President Burgers' absence in Europe to borrow money, General P. J. Joubert, acting president, told me how he distrusted the Hollander influence, which later led to trouble in South Africa. Lord Carnarvon's scheme for Federal Union (as propounded by Froude) was not accepted in the Cape Colony; but Joubert was willing to meet delegates at a central point-Aliwal North-to' discuss the question, and asked me if I would go with him. I was willing, but nothing came of it. Joubert was as genuine an Afrikander as ever Paul Kruger was, but he had different ideas as to what was best for his country, his distrust of the Hollanders, and behind them the Germans, was genuine, and he dreaded the hold they exercised over Mr. Burgers and still more over Paul Kruger. At the time of the Annexation, President Burgers at 
a meeting of leading Boers said that had he listened to the one man who gave him sound advice, but who sometimes opposed him, he would not then be in the unfortunate and humiliated position he was in. When asked who the man was he said, "Struben tried his best to save me and the country, but I was misinformed and misled, I did not know the people of the Transvaal." This was told to me by Wessel Schutte who was at the meeting. President Burgers was accused by the Boers of having sold the country to Shepstone; of using his protest as a blind; of leaving for the Cape Colony with much money and promise of a pension from the British Government. I knew him intimately and I am certain that not one of these accusations were true. He was sentimental and impulsive, and committed grave errors of judgment; but that he was guilty of intentional treachery or wrong doing is untrue, and he lived and died in Cape Colony a poor and disappointed man. Paul Kruger and his Doppers were too "clever" for him. Some of them called him "Antichrist" because of his Church controversies, and his importation of heterodox Hollander parsons. Many Boer families left the Transvaal for Portuguese West Africa as a protest against their own Republican Government at this time. 


\section{CHAPTER XXVI.}

\section{ANNEXATION OF THE TRANSVAAL.}

About the time that Sir Theophilus Shepstone came to Pretoria, a very prominent member of the Natal Legislature wrote to me privately that, although Shepstone was coming to Pretoria, avowedly to see how he could assist in adjusting existing difficulties, he actually had powers to annex the Transvaal, and he thought he would exercise those powers. I had permission to acquaint the Volksraad of this, and asked permission to make a statement. Paul Kruger desired that the public should be excluded, so the doors of the Raad were shut. When I told the Raad and the President that I considered it my duty to inform them, that Sir T. Shepstone intended to annex the Transvaal in the name of Great Britain, that it was the duty of the Raad and the Government to be straight-forward and let Sir T. Shepstone know what they would do in the event of his taking the country. I pointed out that the people had quitted the Cape Colony to get away from British authority and that the Raad must judge whether they were prepared to live quietly under the British Flag again; that as a sworn member of the Transvaal Volksraad, I was in duty bound to assist in any measure for the maintenance of the independence of the country, but that if from vacillation, or despair of getting the country out of its present difficulties, the keys were handed over to Sir T. Shepstone, and I again became a British subject, I would remain loyal to that Government, and that if the Boers afterwards changed their minds, they need not then call upon me to fight because I would not. I put the case as strongly as I could against the annexation, but I could see that many of the members did not care what happened. The 
Chairman asked if I had any objection to a deputation going to Sir T Shepstone to state what I had said and to get a clear declaration from him of his intentions. I said that I wished that they would. They then deputed Messrs. Cornelius Bodenstein and F. Munnik to interview him. On their return, they told the Raad that Shepstone admitted that all Struben had told them was true, but he could not think where I had got my information from. The Chairman then voted me the thanks of the Raad for my conduct in the matter. The Raad was distracted, and again asked me to give my views on the situation. There was much diversity of opinion and much talk, but it was evident that nothing would be done. There was not $10 /$ - in the State Chest; members of the Raad could not get the pay they demanded; the Government had not the confidence of the country, and the people would not support it. As a matter of history, the country was annexed by Sir T. Shepstone by proclamation on the 12th April, 1877, without a shot being fired or a word of protest. Sir T. Shepstone afterwards asked me, why I had forced his hand, by informing the Raad of his intentions; and had in no way assisted him when he thought he could depend upon me, having known me for so many years. I answered that I did not like the way the whole business was conducted; it might be diplomatic but not straight; that I could understand the dominating power in South Africa, asserting that the South African Republic had been allowed a free hand for some years, during which time there had seldom been peace; that the country was bankrupt, and that the Boers had proved themselves incapable of good Government, and were a menance to the peace and progress of South Africa; and that in consequence, the British 
Government would take over and rule the country, and the public should be made aware of the position ; but that I did not like this trading upon the immediate difficulties and fears of the executive and Volksraad, and quiet annexation, and that I feared trouble when the Boers had had time to think over the matter, and had recovered from the present depression, when those who were against the annexation could organise.

Sir T. Shepstone assured me that I was wrong, that many members of the Raad had come to him at night; so as not to be seen by others, and had begged him to go on, and annex the country, and not to mind what they said in the Raad, where they were not free to speak as they wished. I found out that this statement of Sir T. Shepstone was true. Men who talked loudly against the British rule were the first to go to him. There is no room in this memoir to mention a hundredth part of what took place at this time; a full history has been written by others. There is no doubt that Sir T. Shepstone's promise to remit the $£ 10$ war tax, affording a market for produce, and the putting in order of the administrative offices, tended to pacify the Boers at that time. I will only record a few incidents. A brother of $\mathbf{M r}$. Paul Kruger's, Tjaardt Kruger, brought in a load of meal and some slaughter oxen to Pretoria, sold them for a very high price in British coin, and I congratulated him and said that the troops were useful to him in bringing cash. He replied, "Yes, I know that, but all this money I will spend in buying guns and ammunition to shoot them." He then asked me to arrange a duel between him and Sir T. Shepstone on the understanding that if he shot Shepstone, the Transvaal was to be given back, and if Shepstone shot him, he could keep the country. Sir Theophilus 
was sitting on Mr. Lys' verandah when I delivered the message ; and it took me some time to convince him that old Tjaardt was in earnest; when he sent me back to say that in his official capacity he could not accept his proposal. Old Tjaardt said he was a coward, but no blood was shed. After the annexation much money was spent in the country, the people were divided in opinion as to British rule; the Bapedi and Zulu tribes had been subjugated at great cost to Great Britain; the public offices had been established on sound business principles, which they were not before, and the Boers as a whole were apparently contented, with improved conditions. There was, however, all along a section influenced by $\mathrm{Mr}$. P. Kruger and some others, who quietly kept the embers of anti-British sentiment alive, awaiting an opportunity to organise against the British rule when convenient.

Upon the annexation of the Transvaal under. the circumstances known to history, I resigned all official commissions and accepted no office of emolument again in the Transvaal, either under the British, or subsequent Republican rule. I will not attempt to write details of the political situation-records abound and books could be filled. I will only mention a few points that occur to me. When Paul Kruger went on the first deputation to England to get the annexation rescinded, he was in the pay of the British Government. While in London he ran up an account of $£ 1,400$ for hotel expenses at the Albermarle, which he could not pay, so Lord Carnarvon paid it for him, and it was, so it was stated, never repaid.

When Sir Bartle Frere came to Pretoria, in 1879-80, he asked me to allow myself to be appointed a member of the Executive Council, under a scheme 
of administration he intended to inaugurate. I told him that unless Messrs. M. W. Pretorius, P. Kruger and $P$. Joubert, accepted office, I did not think his scheme would be permanently successful. He asked me to see these gentlemen, and try to arrange matters. Messrs. Pretorius and C. Bodenstein were prepared to consider proposals, if other influential Boers would join. P. Kruger would have nothing further to do with it, and the project came to nothing.

I refused to accept office as I considered the scheme unworkable. An Executive was appointed which had no influence in the country and proved a failure. A legacy left by Burgers' government was the Sekukuni trouble. When the Boer commando retreated, some forts were built near the Zulu mountains, and paid volunteers, mostly foreigners, were left to harass the natives, to take their cattle, and prevent them cultivating their crops until another commando could subdue them. For this purpose Sir T. Shepstone despatched Col. Rowlands with a force. On request, I showed Colonel Rowlands and Captain Harvey the map of Sekukuni's country, explained the features as to water, roads, the best approaches to the strongholds, etc., and specially warned them against taking advice from Captain Clark, (afterwards British resident in Basutoland), who was then in Fort Burgers, as he had been unfortunate with Sekukuni and would lead them into difficulties. I knew the country well, but was too busy to go myself, so I hired Franz van der Burg to go with them as a guide. I went with the force as far as Lower Elands River, to help them get " en route," then returned to Pretoria. Rowlands got on as far as near Krokodil Heuvel, when Captain Clark persuaded him that I was wrong. The force was taken back to Olifants River (the old Commando 
drift), and went via Burgers' Fort, down defiles along the Zulu mountains. The men were exhausted, in the burning sun without water, while the Kaffirs sniped them from the hills as they marched down the long kloof, the whole attempt to take the Kaffir strongholds was a fiasco. On his return I saw Col. Rowlands at one of Col. Brook's balls at Pretoria, and said, "You listened to Clark after all, notwithstanding my warning," he said "Please do not say anything about it, I have paid heavily for it." Commissary Sir Emilius Hughes asked me to organise a commissariat train of ox wagons for them as he had been so imposed upon by local men and had been recommended to me. After some demur, I consented, and started at once buying wagons and teams, and hiring others; and my brother Edward went with them through the Sekukuni and Zululand campaigns and gave much satisfaction. This utter failure of Rowlands' expedition had the effect of making the Boers say that the British could not fight, that they need not be afraid of them, and aided the agitators against British rule; and lost us prestige with the native tribes. Subsequently, Sir Garnet Wolseley, with a large force of regulars, volunteers and Swazies conquered the worn out Bapedi, and took the old shrivelled-up Sekukuni prisoner to Pretoria.

After the conclusion of the Sekukuni War, and shortly before Sir Garnet Wolseley left the Transvaal, Sir Owen Lanyon complained to me that he would be in a dangerous position if left without sufficient troops to maintain order in the Transvaal, as Sir Garnet, acting on instructions no doubt, was sending many away. It was not long before the affair at Bronkhorst Spruit started the war, which ended on Majuba in 1881. Sir Owen Lanyon left Pretoria on April 8th, 1881. 


\section{CHAPTER XXVII.}

\section{ZULU WAR OF 1878-1879.}

During and after the Zulu War of 1878-9, I arged that Zululand should be kept as a native reserve, no white man to be allowed to acquire land over the Tugela River, the natives to remain under native law, subject to a low taxation to provide for the salaries of a British Resident and Magistrates. Further, that the Laws in Natal should be made sufficiently stringent to induce the bulk of the lately imported Zulus to re-migrate into the reserve, and to some extent deplete Natal of a rapidly increasing but non-working black population, which might at any time become a source of danger owing to agrarian trouble; as they with their system of cultivation and stock raising require such large areas for occupation.

My idea then being to retain the temperate portion of South Africa for the white man, such zone to be determined by a railway system from Cape Town to Delagoa Bay to begin with, and to be extended with increase of population. The chance of carrying out such a policy was made impossible by Sir Garnet Wolseley's settlement of Zululand, and the subsequent action of Mr. Gladstone's Government, which refused to accept any responsibility for the country. Dinizulu, aided by the Utrecht Boers, defeated the loyal chief "Usibepu," the principal chief of Sir Garnet's appointing. The Boers acquired the district of Vrijheid, then in Zululand. Dinizulu, who was found to be the centre of unrest, was deported to St. Helena, but was repatriated later 
owing to the influence of Miss Colenso. He was again the cause of unrest, culminating in the Bambata insurrection, which was suppressed by the Natal volunteer forces. Dinizulu was then placed on a farm near Middelburg, Transvaal. During the Zulu War I was in Utrecht, and walking outside the town with my brother Fred, met a messenger who had ridden hard from Helpmakaar with tidings of Lord Chelmsford's disaster at Isandhlwana, and Chermside's defence of Rorke's Drift. Sir Theophilus Shepstone (who was then in Utrecht), was overcome at these tidings as his son George was with the Natal Volunteers under the ill-fated Major Durnford (of Bushman's Pass notoriety), and he asked me to read the despatches. The Magistrate who was present exclaimed, "We are all lost, the Zulus will be here directly." I begged him not to create a panic in the town and laager and to keep calm. Sir Theophilus gave me full power to do what I thought best, to put the place in a condition to stand an attack, as there were many women and children in a small laager, and some military stores. There were some three or four hundred native followers of a supposed loyal chief, Oham, quartered near the village, so I appointed two young Boers, Lombard and Potgieter, I think their names were, to supervise these Kaffirs, and after buying up all the shovels and pickaxes in the town, we set the Kaffirs to dig a moat round the women's laager, leaving a foot wide margin below the wall, which I packed with broken bottles. I had sand bags placed on the walls with loop holes, a wooden platform along the inside for a second line of sharp-shooters above the lower loopholes, and two heavy gates and a drawbridge constructed, had stores carried in, and I am sure that the Zulus could not have taken the laager when I had finished it. During the work, Oham's Kaffirs 
frequently bolted, as they were not used to spade and pick, but my lieutenants, Lombard and Potgieter, who were mounted, drove them back into the moat with sjamboks. These Kaffirs complained to Sir Theophilus that I overworked them, and he asked me to be more lenient with them, but I said it was war time, and they must do their work. People in the laager overheard them say that they would kill me, and begged me to sleep in the laager, and not in a cottage of Birkenstock's, on the outskirts of the village, but I knew that the Zulus would not expect any one to be there, and that I would be safe. The people in the laager were grateful and signed a round-robin thanking me for the work I did. My brother Fred went on and joined Wood's Flying column, and took part in the fight at Kambula. Sir Theophilus wished to communicate with the column, so I commandeered a horse from a young Boer for the messenger. I also wrote to my brother Edward who was with the column, and to Colonel Gilbert, in command of the 13th Regiment, whom I knew very well, and also to Piet Uys, begging them to come out of the broken country of the Makulusine into the open, to laager and prepare for a Zulu attack. Uys and Colonel Weatherley were there with many others, including R. Lys' brother. The sons of the two former were trapped and killed at Hlobane, but the laager in the open at Kambula withstood the attack, chiefly owing to the pluck and discipline of the old 13th Regiment.

My wagons went over the Drakensberg into Zululand, where I had altogether 131 teams of 14 oxen each, about 300 men (white conductors and native hands) under Edward and afterwards under Fred's control with Sir Evelyn Wood's Flying Column. I had to send hundreds of oxen to fill the 
teams, as many died from overwork and bad feeding, and many were killed at the attack on Kambula camp. On this and other occasions, Fred behaved very well, was mentioned in despatches; and was to receive a medal, but being only a civilian, I do not think he ever got it.

Nearly all the Basutos bolted when they saw the Zulus swarming on to the laager. None of ours did, but they behaved pluckily in defending the cattle laager, killing Zulus among the cattle. After the fight General Wood asked them who they belonged to, and why they did not run away with all the other camp-followers. They said they were afraid of the Zulus but could not run away, as they would be ashamed to meet their master. One poor fellow, who was a distance from camp gathering wood, could not get back, so made for Pretoria, and sent me a messenger explaining his position and asking if I would receive him, which I did. I used to send troops of 500 oxen at a time all the way from Pretoria into Zululand, with only two of my natives in charge and never lost any, except two which were drowned when crossing a swollen river. My natives fully trusted me and I them. I had terribly hard work at this time to keep all these wagons, oxen and men up to requirements, but felt all must help when the savages were on the war-path; and I worked day and night until I was nearly done up. Commissary General Sir E. Hughes said that ours was the best organised and most honestly run commissariat train during these wars. It was common knowledge that there was abominable swindling and bribery in Natal, with some of the columns.

When I had completed the Utrecht laager, at Sir Theophilus' request, I accompanied him to the top of Laings Nek on the Drakensberg, then went 
with proclamations among the Wakkerstroom Boers with orders to recruit as many as I could, to go to Utrecht and the border to prevent Zulu inroads. I obtained only two men, Englishmen, to go to the front. The Boers told me that Shepstone had annexed the Transvaal, and he could manage as best he could : they were not going to fight for the English and recommended me to throw Shepstone's proclamations away. They knew and liked me, but some extreme ones might punch my head if I showed them elsewhere. I left my tired horses at Rolfontein and got fresh ones, but my attempts to persuade the Boers to assist in the campaign were fruitless, and I went to Standerton to report to Sir T. Shepstone on the temper of the people. He soon after went across country via Harrismith to Maritzburg and I returned to Pretoria.

A strange thing happened at this time. I was walking with Sir Theophilus Shepstone outside Utrecht, discussing the situation, when suddenly it became dark, and for a moment neither of us realised that it was a total eclipse of the sun. When we did he said "Struben this may have a strange effect on the Zulus, who are superstitious". Next day we heard of the disaster at Isandhlwana and he said to some old Kaffirs who came to hear news "Umtwan ami u fele, George ugwazile." "My child is dead, George is stabbed," and he was quite overcome. The history of the Zulu war has been written, and I will not attempt to repeat it. After the battle of Ulundi, Sir Garnet Wolseley came on the scene and made the unfortunate settlement of Zululand by appointing thirteen chiefs, among others, an Englishman, John Dunn. This man was accused of gunrunning up to the time of, and after Sir Bartle Frere's ultimatum to Cetchewayo. He had a harem 
of Kaffir wives, one of whom was the Zulu king's daughter. When Dunn saw how things were going, he deserted the Zulu king, being subsequently given a large district to rule over. One night at dinner in Pretoria I was sitting next Sir Garnet Wolseley and he was discussing the position in Zululand, when I, in answer to a question, told him that the settlement did not meet with the approval of the colonists, and especially the giving of a chieftainship to Dunn,which was putting a premium on moral depravity and gun running. He got so annoyed with me that he wished us "good night" and went into his room, I was hauled over the coals by some of his staff for speaking too plainly. However a few days afterwards he spent a day at "The Willows" and discussed the questions of the day with me. At this time Captain Paterson and a party were sent from Pretoria on a diplomatic visit to Lobengula-an inappropriate time when the native mind was disturbed by recent native wars and political changes in the Transvaal. The whole party were murdered by the Matabele-only one Hottentot servant escaped. 


\section{CHAPTER XXVIII.}

\section{TRAVELS IN EUROPE.}

For some years I had wished to revisit Europe which I had not seen since I left it as a boy from school in 1850, but something had always prevented my leaving the Transvaal. However, we determined to go at last. We started via Natal and the East Coast on February 19th, 1880.

We first visited Delagoa Bay, which was then a miserable fever-stricken village of a few houses. The place was bankrupt, the little black soldiers were months in arrears of pay, and the mutinous official's salaries were unpaid. The only source of revenue was a tax of $£ 1$ per head imposed on natives returning from Natal sugar plantations. I found the Eastern Telegraph clerks operating in a small tin hut, all down with fever, and reported to. Sir Bartle Frere at Cape Town on this and other matters. When I arrived in England, I found letters from Sir Bartle Frere introducing me to the Secretary of State for the Colonies, Lord Kimberley, and to Mr. (afterwards Sir Robert) Herbert, Permanent Under-Secretary. The latter was an intelligent and able official, full of knowledge of Colonial affairs, and took much interest in my report. At this time, the Transvaal, was in possession of the British, who had their ports of entry in Natal and Cape Colony: Delagoa Bay was of little value to Portugal, and I strongly urged the authorities in Downing Street to acquire it, as it could be had cheaply then, and if in British hands, would make a South African war (engineered by European powers) 
impossible. Portugal owed England $£ 14,000,000$ and interest accumulated, since the Peninsula War. This debt cancelled and a small sum in cash would have settled the matter. Mr. Herbert wrote about it to Lord Kimberley, who was in the country, but he did nothing and then when I had taken passages to return to South Africa, wrote asking me to put off my departure, and to await his arrival in London, but as news of the unrest in the Transvaal made me anxious, I left and did not see him. George Moodie also went with me once to aid in endeavouring to persuade the British Government to move in this matter, but as Gladstone's party was in power, they would do nothing. I had previously urged this on Sir Garnet Wolseley when he was in Pretoria, but the British Government were too slow. Now British capital has made Delagoa Bay an important seaport and town, and millions would be required to do what thousands would have done then. Its railway commands a large share of Transvaal trade, while it is one of the most valuable coaling harbours south of the line.

On reaching Zanzibar the S.S. "Nyansa" was sold to Sultan Bargash, so we went on in a British India S.S. We had some very enjoyable rides about the island, the Sultan providing ponies, but we had to start very early to avoid the heat. We passed one morning a large traction engine buried axledeep in sand and rusting away. This had been sent out by some philanthropic old ladies in England to haul cocoanuts and bananas and other products to Zanzibar market, as they had heard harrowing tales of how the poor enslaved natives carried them on their heads. I discussed with Dr. (now Sir John) Kirk and Bishop Steer, the advisability of occupying the fine forest-clad and snow-capped mountain 
"Kilimanjaro" with a mission station; pointing out that this would appeal to the British public, and secure a base of operations into the interior, strengthening the British position in East Africa. Caravans could go from Bogoyomo (the port of entry) in winter, and post runners in summer would keep communication open. The highland was perfectly healthy, and commands Ugii on Lake Tanganyika, to the west and Victoria Nyansa on the north. They fully agreed but said that the British Government would never move in the matter. The whole territory, including Kilimanjaro has now been painted yellow on the map by Germany, (1911). The many lives lost and millions spent by England in suppressing the Arab Slave Trade have been thrown away as far as the vast territory claimed by Germany is concerned. We now retain Zanzibar, Pemba Islands and Mombasa, and the territory to the east of Lake Victoria Nyansa.

Whilst travelling on the Continent, disquietening news caused us to leave sooner than we otherwise would have done, and regretfully we left for England. We landed at Southampton on a miserable wet Sunday, I thought it was the most dismal place I had ever seen. I have never got over my impresssion of the English climate received on this visit to England, after an absence of exactly 30 years, that is from 1850 to 1880 . 


\section{CHAPTER XXIX. \\ RETURN TO SOUTH AFRICA.}

\section{FIRST BOER WAR.}

As the news from the Transvaal was so bad and the possibility of war imminent, we had to curtail our visit to England as it seemed necessary to be in Africa at such a crisis, so made up our minds to leave almost at once. We started for South Africa in the "Kinfauns Castle" with Captain Robinson in command, on October 25th, 1880. On arriving in Natal, I at once bought two wagons and oxen to travel to Pretoria, but war had broken out, the Bronkhorst Spruit disaster had taken place and the roads were closed. I made frequent efforts to get to Pretoria but was not allowed, so was obliged to remain in Durban, arranging for landing and transporting furniture, machinery, etc., which we had brought from England.

Sir George Colley, whom I had known in Pretoria, sent an orderly to me frequently, to let me know when I could get through, but we never succeeded until the war was over. I was anxious to get up, as our children were on "The Willows" and afterwards in the siege of Pretoria, but we could get no news about them. I saw Sir George Colley often and very soon came to the conclusion that he underrated the capabilities of the Boers as irregular troops, as sharpshooters and as veldsmen; and I anticipated the reverse he met with. $\mathrm{He}$ was a nervous, sensitive man, and appears to have lost his head after the Ingogo fight. 
I drove to Harrismith and met the remnant of the regiment which had been cut up at Bronkhorst Spruit. No two of them gave me the same account of this disaster. I also learnt that it was impossible for me to get to Pretoria that way, as Captain Elliott had been shot in cold blood, while crossing the Vaal River with Captain Lambert. I afterwards stayed with Lambert in the same club in Maritzburg and heard all about it. I had written to General Piet Joubert asking him to send me a free pass to go through their lines at Laings Nek to Pretoria, but he informed me that the "Krijgsraad" would not grant one. Old Conrad Pietersen, on whose farm the now famous Pieters Hill is situated, a wealthy Boer, who had been in our neighbourhood when we lived on Ruitenburg and who was a so called friend, refused to let me his furnished but vacant house in Ladysmith, and we had to draw the wagon near to the Dutch Church, and Mary who did not wish to return to Maritzburg (hoping to be able to get on soon), had to live in the vestry which was placed at her disposal by the minister Mr Kriel. It was a trying, weary time. One day a detachment of troops were crossing the Klip River and I noticed a Boer sitting above the drift taking down their numbers. As soon as they were all counted, he rode quickly away through the poort. These troops were under Colonel Ashburnham, who was advised to push on to Newcastle. He escaped being ambushed on the Biggarsburg by a couple of hours. Anyone can read all about the war of 1880 in detail in books, despatches and newspapers, and I will not repeat.

I returned and stayed in Durban, where the latest news was obtainable as the war dragged on. I took Mary back to Estcourt, where I hired a small house, and used to visit the little family there from 
time to time, but I could do nothing until peace was declared by Gladstone, after the reverses at Ingogo and Laings Nek and Majuba. During my stay in Ladysmith Sir George Colley passed through to the front. A rumour was about that Boers were inciting natives and using them against the British, and that Sir George Colley intended to use the natives against the Boers in retaliation. I at once wrote a strongly worded letter to him, (a copy of which I have) begging him not to employ blacks to fight against whites under any conditions and warning him of the lasting ill consequences of such action. I have since learnt that there was never any intention on his part to use native levies. At Estcourt I kept a cart and four horses ready, and the day peace was declared, mother and I started for Pretoria. On arrival at Heidelberg, we found the Provisional Government and Mr. Paul Kruger established there. The village was fúll of people and lodgings were difficult to obtain, but Sir Morrison Barlow, who had been taken prisoner in Swaziland (where he was acting as magistrate), and brought to Heidelberg gave up his room to us. Soon after my arrival Mr. Kruger sent Dr. Jorissen and Secretary Edouard Bok, to ask me to re-enter political life, and assist the new Government. They stayed until quite late and prevented us having dinner. Notwithstanding their arguments and promises, I refused to promise anything, as I intended to see what had really happened in Pretoria, and to my children and property before committing myself. Mr. Kruger was annoyed at my refusal. Next day in Pretoria we found the children looking miserable, having been half starved on boiled kaffir corn and third-rate rations while in camp during the siege of Pretoria. On the other hand the troops and favoured individuals were being fed on the fat cattle and produce 
taken from $m y$ farms, and for which I was never paid. I found "The Willows" for all practical purposes wrecked, not a moving thing left, all my papers destroyed, livestock, implements, machinery, produce, all taken. We felt so bitter that Mary decided to return to Natal. After arranging what matters I could, I bought a wagon and team of oxen from Rider Haggard, and sent the family off with two old "Willows" natives. I had to remain behind in Pretoria to settle some matters and followed in my horse cart. I slept at Heidelberg. The hotel was very full, so they made me up a bed on the floor in the drawing-room. Later, as I was falling asleep, the proprieter came to ask me if I would mind his putting up Mr. Aylward in the same room. I said no, that I was fully armed and I could shoot him if necessary. They made his bed fairly close to mine but when Mr. Aylward came in and found out who I was, he would not sleep there, and they removed his bed elsewhere. The scoundrel had been implicated in some Fenian atrocities in Ireland, and headed a seditious insurrection on the diamond fields. $\mathrm{He}$ had come to work up sedition in the Transvaal against the British Government. I was told afterwards that he was an arrant coward, and could not sleep at night unless someone he knew was in the same room, and kept a light burning. I paid my score and got the key of the stable from the landlord intending to start at daylight, but in the night I got restless, as there had been heavy rain and only Kaffirs were with Mary and the children, so at midnight I started to follow the wagon. It was fortunately light when I came to where the two roads parted, and I saw that the boys had taken the wrong one. I drove on as fast as I could, found the wagon stuck in the middle of Vaal River, the span of oxen all twisted up in a heap, the Kaffirs shiver- 
ing with cold and quite demoralised, Mary and the children were sitting on the cartel bed, the water was running through the wagon, and the river was rising fast. I did my best to get the oxen to pull, but they had been too long in the water, and were not a good span at best, so all I could do was to get the wagon near the bank and gallop up to a Boer farm for fresh oxen. At first the man said he had no oxen, but when I told him there was a mother and children in the wagon and that if they were drowned it would lie at his door, he said he would send the oxen if I would pay him $£ 3$, which I did. $\mathrm{He}$ brought a fine team of fat oxen which, with our assistance, got the wagon up the steep mud bank. Had I waited at Heidelberg for daylight the whole family would have been drowned; as the two Kaffirs were quite helpless and the children all small. Mary was, as usual, calm and brave, but fortunately she did not quite realise the great danger they were in. We trekked down to Maritzburg, where I hired a house from Offie Stepstone. It was a miserable time-I had nothing to do and was spending money all the time, and I cursed the day when I had to return to Africa, which was never at peace.

Among other things which I had imported to take to Pretoria were implements, fencing material, a steam engine and sawing plant, large water pipes and sluice valves, also a brick and tile making plant. My brother Fred who had nothing to do, took over the latter and started making excellent ornamental bricks, tiles, flowerpots, etc., at Isipingo, Natal.

I started alone for Pretoria to try and save what I could out of the wreck of my affairs. I was outspanned at Sand Spruit beyond what is now Volksrust, when I saw a storm gathering, so started 
in haste for Paardekop, where there was an hotel of sorts. A terrific storm of wind, hail, and sleet caught me a few miles from the starting point and and I had to put down the hood to save the "spider" from blowing over, while I could hardly keep the horses on the road. When I reached Paardekop my little groom Kleinboy, was frozen and of no use. I drove the spider to the side of the house, and went to get assistance; but the Jew who kept the hotel refused to come out, saying it would kill him to do so. There was no one to help, so I unharnessed the horses in the hurricane and had just put them in the stable when the roof blew off and the wind took it down the hill. The hotel was an iron building, the snow drove through the joints and made strips across the floor. The Jew said he had no food, but could let me have some gin, I told him he lied because I had seen him eating dinner in the next room. After some strong language he gave me a meal of sorts, and a glass of gin, and I had to attend to the frozen Kleinboy.

A poor delicate little clergyman with his wife and child told me that the Jew would not let them have any food, and that they were almost starving. I made the miserable hotel-keeper give them some food at once, and I paid for it. During a lull in the storm, Robert Preller (whose farm-house was close by over the Spruit) came for a flask of gin, I persuaded him to give me room for my horses and self, and he helped me to inspan and to get over to his farm. This saved the lives of my horses, if not my own as the storm broke out again, and we were snowed up for three days, in the most bitterly cold blizzard I have ever experienced. The snow was driven over the high range, and was six feet deep at the homestead. I got compressed forage from the Commis- 
sariat, and, as we could not get at the spring, boiled snow for the horses to drink, and so saved their lives. As soon as I could get to the hotel, I went to see how the poor little parson and his wife were faring. They were miserable, and, as the weather showed signs of clearing, had decided to go on to Standerton with a Commissariat wagon which was leaving, as the hotel keeper was treating them so badly. They had only got to an iron stable, a few miles further on, when the snow storm broke again, and there $I$ found them three days later. They reached Standerton in time, but the poor little man died soon after arrival. Preller's cattle were buried in the kraal several feet deep, and when the snow melted, there was not one of the seventy-six alive. His sheep had run down the wind, and he and I tried to find them, but the snow blizzard drove us back home. The running saved their lives. After the storm he found them on a farm of mine, "Haartebeesthoek" on the Vaal River. All the way to Pretoria (via Heidelberg) I saw thousands of dead animals, cattle, sheep and goats, etc., and again from Pretoria to Kimberley, where I went some time afterwards. The country was denuded of livestock, the loss all through the Free State and the Transvaal High-veld was immense as the Boers seldom provided shelter for their livestock. In Pretoria I had no pleasant task. The Boers had taken part of my property from "The Willows" and the British my cattle and farm produce for the troops. The Boers had made "The Willows" the headquarters of one of their commandoes, staying on the homestead during the day, and sleeping all about the rocky bush-covered hill at night. Nothing was left in the house except the oil paintings and portraits of my parents and grandparents, which I afterwards learned were spared owing to the influence of Karl Erasmus, who was 
married to the daughter of my good old friend Joachim Prinsloo, Landdrost of Pretoria. Outside, everything had gone excepting the frame of a large steam wheat-thrashing machine, of which bolts, wheels, sieves, etc., etc., had been taken away. I found that some of my immediate Boer neighbours had most of my things. At the retrocession the British Government undertook to compensate those who had been pillaged. On the 13th of June, 1881, Sir Hercules Robinson, Governor of the Cape Colony, and General Evelyn Wood arrived in Pretoria. On August the 3rd, 1881, the Pretoria Convention was signed, and on the 21st September the last British troops left the Transvaal. Sir Owen Lanyon, who had become Administrator on March 5th, 1879, left Pretoria 8th April, 1881. Sir John Brand, President of the Orange Free State had arrived in Pretoria on June 8th, 1881, to join with Sir H. Robinson, General Evelyn Wood and Chief Justice de Villiers, in handing back the Transvaal to the Boers, after the fight of Majuba (on the 27th February, 1881). Mr. Gladstone decided to abandon the country, and carry out the programme as announced in the Midlothian election campaign. Among other events Sir $\mathrm{H}$. Robinson called a meeting of native chiefs at which I was present. He explained to them that the white Queen over the water did not wish to fight the Boers, so had given the Transvaal back to them with all the natives, English residents, etc., and told them to be law-abiding, faithful subjects to the Boer Republic. He introduced General Piet Joubert (who sat on his right hand) as Minister for Native Affairs in place of Henriqué Shepstone. The natives asked why they had paid taxes to the British (under promise of protection) while they were now being handed over to the Boers, etc. It was a most humiliating spectacle! 
There were many incidents during the war of 1880-1881 which one would like to forget.

God grant that foreign intrigue will not bring about any more trouble between the British and the Boer in South Africa, where they must live together in unity, if the country is not to revert to barbarism and the reign of the black man. I mentioned some way back that all my selected cattle, oathay and mealies had been taken from "The Willows" by the British Military Authorities at the outbreak of the war, and I was tendered a price so inadequate, that I refused to accept it. Judge De Wet, who evidently had been primed, told me that I had been abominably treated, worse than any others and he recommended me to try the case in court. I obtained an interdict on stores to found jurisdiction, then Ceneral Bellairs and George Hudson asked me to submit the case to arbitration and not to sue the authorities. After many promises, I agreed, and they asked me if I would object to Judge De Wet as arbitrator. After the way he had expressed himself to me, I naturally thought he would be impartial, accepted him, and withdrew the interdict. $\mathrm{He}$, after keeping me waiting for months, sent me a dirty, little crumpled piece of paper, on which he stated that "Mr. Struben had no claim whatever." This man was given a judgeship in Ceylon because he understood Roman-Dutch Law. George Hudson and Dr. Dyer indirectly had the paying out of compensation claims, with Dr. Rutherford as secretary. Claims were treated in a most callous manner. I myself heard Hudson (who was going out shooting), answer a question as to what valuation to put on a claim, which he had not seen, "Oh, cut it down about two-thirds, that will be near enough." Dr. Dyer bought up a good many claims from people who did not know what they 
might get. This business almost ruined me for the third time in my life. On the 14th May 1881, I wrote to the Royal Commission presided over by Sir Hercules Robinson, showing my position prior to the annexation and the losses I had suffered since then, and during the war, but no notice was taken of my letter. After our pleasant voyaging in the East and in Europe, this coming back to a ruined home in South Africa, and with a large family to provide for and no prospect of improving my position, was almost too much for me. The brave little mother and I went through a sad and anxious time.

After the 1880 war when nearly all my diaries, private and political papers, family relics, etc., were destroyed, myself nearly ruined, and the country so miserably poor, that it was a hard struggle to keep my family, I turned to anything I could think of to earn a livelihood. I tried various branches of farming, and did some prospecting. A bad drought in 1883 handicapped me. I was tired to death, and getting to hate the couutry, and all connected with it. There was no justice obtainable from the local officials; even the Bench was not respected, and I wanted to sell out and leave, but there was nobody to buy, no trust, no hope, for the future of the country, under misrule. At the retrocession, the bulk of English-speaking people who could, left the Transvaal. There was no money in the Exchequer and no credit, and the granting of concessions became the order of the day on everything conceivable from jam to dynamite, from land areas to brandy monopoly and a few patriotic foreigners did well. If I could have sold out, I with my brothers intended going to New Zealand but were unable to do so, as we could get no one to buy anything. 
In January 1883 the Boers went to war with Mapoch; and the Field Cornet took all my working oxen out of the ploughs on "The Willows" to pull their guns; and all my native servants as camp followers, so that all farm working was stopped. Being an English individual I had to supply as much to a commando, as any dozen of my Boer neighbours.

For fear that by any possibility there might be a term of peace and industry in the Transvaal, the Boers declared Republics in Stellaland and Rooigrond and one, styling himself President Van Niekerk issued bloodthirsty proclamations and for some time kept the western border in a state of anarchy. 


\section{CHAPTER XXX.}

\section{AFTER THE RETROCESSION.}

The Transvaal Boers most cordially disliked and despised the Hollanders dwelling among them, but on account of their speaking Dutch and being useful to write official documents and keep accounts, they tolerated and used them. Dr. Leyds (who was born in Borneo) and was a school-master, succeeded in ingratiating himself with President Kruger. $\mathrm{He}$ had written a letter to a friend in Holland speaking in a most insulting manner of the Transvaal Boers. This letter was sent back from Holland to the Transvaal, was read out to the Volksraad, and caused great indignation, but as he was so intimate with Transvaal affairs, Mr. Kruger defended him, and smoothed it over.

When the state income from the Rand Goldfields exceeded the Kruger dreams of avarice, a secret service fund was started, and Dr. Leyds was credited with handling large sums, The money was mostly used to purchase cannon, rifles, ammunition, to prepare to fight the British, and establish Republican rule over South Africa, it was hoped with the assistance of Germany and Holland. The deepseated animosity of the Dutch Afrikander against the British is mainly due to the injudicious manner in which the emancipation of the slaves was carried out in 1838.

On March 26th, 1713, England made a treaty with Spain "The Asiento de Negros" by which she secured the monopoly of supplying slaves to the Spanish 
colonies, and the greater portion of the slave trade all over the world was carried on in English ships, and with the knowledge of the English poeple. In view of this, and notwithstanding the philanthropic feeling which prompted the Act of Emancipation, the arbitrary manner in which slave owners were treated, the way they were paid, the partial compensation awarded, the disorganisation, (social, industrial and commercial) involved could not be justified. The gradual emancipation, (having due consideration for the industrial interest of the community ) they could understand, but the sudden cessation of work and the consequent ruin, they could not forget. The West Indies were also ruined in like manner. Again, the policy pursued by the British Government towards the turbulent and raiding native tribes on the Eastern borders; and especially the ill-considered act of Lord Glenelg in siding with and re-instating the Kaffirs after heavy sacrifices made by the burghers and British troops-in driving the marauders out of the colonycaused thousands of people to seek homes elsewhere. At the same time it must be admitted that the South African Boers were not satisfied under any Government. They had been insubordinate under the Dutch or Batavian rule, and subsequently under the British and the Transvaal Boer Government, but they made no allowance for that. They only remembered what they considered the harsh and unsympathetic treatment of the ruling authorities. As their history shows, since the days of the old Batavian Government, the Dutch Boers have been intolerant of strict discipline, of taxation or any restrictions. Although they did not go to extremes, there were frequent dissensions among the parties of trekkers during the occupation of the Free State, 
Natal and Transvaal and the Boer Civil War of 1864. The consequent issue of paper money, the ruin of commercial houses, the total absence of credit, the stoppage of all progress or development, the hopeless state of insolvency in the Transvaal and the discontent of the burghers with their own Republican administration was the cause of the annexation of the Transvaal by Sir T. Shepstone in 187\%. Since these wars, free institutions have been granted to the whole of South Africa, including the conquered Republics.

The Union of South Africa has been established and a Dutch Afrikander Ministry rules the land. It now remains to be seen whether the Government will prove capable of welding the several nationalities and communities into a real and not a sham Union, or whether the back-veld Boer will be exploited by unscrupulous or fanatical agitators, to obstruct the Government, and block all progress of useful development.

In 1875 a second large party of Boers trekked to Damaraland, the first lot having gone in 1874 . They were mostly Doppers and left the Transvaal because they did not trust their own Government, and objected to the laws passed, and to the state of general unrest and poverty due to mis-government.

These Trek-Boers (after terrible privations), eventually settled in the Province of Angola at Mossamedes. The curious feature of this exodus was that they left the Transvaal Republic ostensibly on account af the Church not being orthodox (that is Calvinistic), and the selection of Thomas Burgers, a Dutch-Reformed minister of Hanover, Cape Colony, as President (Mr. Burgers had started a controversy on certain passages in the Bible); yet they placed 
themselves under the authority of a Roman Catholic Government, and intermixed with Roman Catholic Portuguese, some of the marriages being rather irregular. Others trekked to German South West Africa, but most of these returned, as they could not stand German authority and their stringent rule. Since 1900, some have gone to the Argentine, to Brazil, British East Africa and Rhodesia. When once a Boer sells his farm, he becomes either a loafer about the town, or he treks away to seek undeveloped land, where game is plentiful, labour cheap and life primitive. 


\section{CHAPTER XXXI.}

\section{A GENERAL SURVEY AND SUMMARY}

OF EVENTS.

I could write pages of the events preceding, during and after the war of 1880 , but no good purpose would be served. Enough has been written about the military and political muddles of these times, as well as of the nepotism and bribery, the concessionmongering which was rampant in the Transvaal after the retrocession; the policy which led up to the Jameson raid, and subsequently the great war of 1900 , when the Republics took the offensive. The whirligig of time brings strange things to pass! In 1857 Kruger raided the Free States, in 1896 Jameson raided Kruger. The Boers raided Bechuanaland and Zululand with Kruger's approval and tried Matabeland. Rhodes and Jameson annexed and populated it. Jameson and his friends paid tens of thousands in fines. Kruger \& Co. paid nothing and obtained land! During the sixty odd years of my sojourn in it, South Africa has never had rest, never known real peace, or been able to concentrate its energies on industrial and commercial development like other countries. One never knows what will happen! I remember Sir Garnet Wolseley discussing with me the advisability of proclaiming the country up to the Zambesi River as an annexure or portion of the Transvaal. I pointed out that in the event of a Liberal Government coming into power, and that if according to Gladstone's speeches the Transvaal were given back, it would involve the session of what is now Rhodesia and would probably become German 
territory. With party Government in England, the colonies never know what policy will be pursued; as everything is sacrificed to party.

On April 4th, 1860 the district of Lydenburg (which since 1857 had been an independent Republic) was incorporated in the South African Republic, largely owing to the influence that my father exercised with the Lydenburg people. He became secretary to the Government in 1860 . On June 12th 1865, the Republican Government issued paper money in notes from $1 / 6$ to $£ 5$ face value, but they were not backed by any coin in the treasury, and were worth only from $2 / 6$ to $5 /-$ in the $£ 1$. The issue continued to 1868 , and the notes were signed by M. W. Pretorius, State President, M. W. Viljoen, Member of the Executive, and C. I. Joubert, Member of Commission, H. v.d. Linden, Treasurer. They afterwards became a forced legal tender at par; to the ruin of bond holders and merchants, and were ultimately redeemed by the Cape Commercial Bank when Mr. Burgers became President in 1872. These notes were issued to redeem the "Maandaten " or Treasury Bonds, after the Civil War of 1864. The Boers in Potchefstroom and elsewhere, who owed bills for coin (British currency), agitated for proclaiming the notes a legal tender, and men who had been given credit and extensions of time for years, rushed off to pay their debts with this worthless paper. I was a victim for what at that time, were to me, considerable sums, and as the Cape Colonial merchant would not accept the paper, many shopkeepers were ruined. Many of these Boers, who were well off, paid their debts at $2 / 6$ in the $£ 1$, and thought themselves clever.

The Sekukuni and Zulu Wars undertaken to protect the Transvaal in 1878 to 1879 , cost Great 
Britain fourteen million pounds sterling. As the settlement (owing to Mr. Gladstone refusing to accept the responsibility of administrating Zululand), was a fiasco, Boer speculators were allowed to annex the best part of it as an independent Republic, which was subsequently incorporated with the Transvaal. After the Retrocession of the Transvaal in 1881, concessions were freely granted to foreigners, Hollanders, Germans, Frenchmen, for making gunpowder, for distilling spirits, for the public salt pan, for iron smelting, for making jam and soap, a bank and mint, for railways, etc., etc. The country was run for the benefit of "continentals," Mr. Kruger's one idea being to keep the British out at any cost as participants in these concessions, but to allow them to contribute the bulk of the revenue. One remembers the closing of the "Drifts" and'the special taxation without representation and other matters which eventually culminated in the Jameson Raid, and ultimately in the war of 1900.

At the time of the discovery of the diamond fields in $18 \%$, the whole of South Africa was practically bankrupt. The Transvaal was hopelessly insolvent. A British $£ 1$ sterling was almost unobtainable, and in cases where it was absolutely necessary, it cost about $£ 4$ or $£ 5$ to get it. It was a bitter struggle to bring up a family respectably and keep out of debt in those days. There were no railways or markets. The Boers were really hunters not farmers, growing only enough for their own wants. Their only extravagances were "salted" shooting horses, rifles and ammunition, but they managed to live somehow, and were as happy as they are now. The opening of the Diamond Fields, and subsequently in 1873 of the Lydenberg Gold Fields followed in 1884 by the discovery of the 
Witwatersrand Gold Fields, entirely altered the conditions of life in South Africa, both for the white and coloured inhabitants. Labour has been in demand at high wages, railways have superseded the ox-wagon, towns have been built, banks established with a coin currency, and inter-communication is rapid and convenient. Those people who do little or nothing themselves, should be less prone to abuse the so called mining magnates, who have brought in millions of capital to develop the resources of this country, which, if dependent on the enterprise of the old inhabitants might have remained dormant another ten centuries. Agriculture in all its branches would have also stood still, but for the infusion of fresh blood, the object-lessons given, and the new methods introduced. I am of opinion, that unless oversea immigration is encouraged, South Africa will slowly but surely revert to the dark races, and become again barbarous. The children of the old Boer pioneers as a rule are going backward; they will not farm properly themselves, but let the Kaffirs work their farms on shares. The consequence is, and must be, that the Kaffirs are becoming industrious farmers, white owners are drifting into the towns, and many becoming " poor whites," and a burden to the State. Many children of leading land owners of the last generation have squandered their land and money, and are now asking for Government support. While under Sir Richard Southey, as Governor of Griquland West (including the diamond fields), permission was granted diggers and companies to pay their natives wages with fire-arms instead of money; and thousands of guns (mostly of very inferior quality) were obtained by Kaffirs hailing from various tribes, Sekukuni, Zoutpansberg Mountain tribes, Natal 
Zulus and Basutos, etc., in the other British Colonies and in the independent Boer States the sale of arms and ammunition to natives was a criminal offence. The Free State protested against the armed Basutos passing through their territory to Basutoland. In Natal the authorities demanded that all fire-arms in possession of natives should be registered. The result was that when Langalibalele's tribe refused to ragister their arms, fighting followed. The tribe was dispersed and Langalibalele sent a prisoner to the Cape Peninsula. The inconsistent and mischievous policy was disgraceful on the part of the Government and led to disturbance and bloodshed, while it made the Boers more than ever distrust the British native policy, which has by vacillation and inconsistency, (due largely to changes of party Government in Great Britain,) done more to retard the progress and quiet settlement of South Africa than anything else. It is to be hoped that under a Union Government a uniform policy based upon justice and common sense, with a due regard to the maintenance of the supremacy of the white races as the civilising factor in the future will be pursued.

I remember very often going with the late $\mathrm{Mr}$. Harry Escombe to inspect the works at the port of Durban, in which he took such great interest, and he would rejoice to-day if he could see the splendid advance the plucky little Colony has made since then. When Indian coolies were introduced to work at sugar plantations (as the Kaffirs would not work) I pointed out to him the danger I foresaw of these Asiatics, finding the climate and conditions favourable, remaining in the colony and increasing the already swarming coloured population, and that they would, when their terms of indenture expired, start cultivating and trading on their own 
account, and employ the very natives they came to replace. I suggested that their contracts should terminate in India, not in Natal, and that the employers should be bound to re-ship them to India, that any other indentured Indians should be subject to a considerable immigration tax, and even then the number allowed into the country should be strictly limited. $\mathrm{He}$ thought that I was unduly alarmed at the time, but subsequently asked me to put my ideas in writing, which I did. It was, however, the usual shutting the door too late. The Indian has now practically possession of Natal, their numbers exceed the whites, they have ruined and driven out the smaller white trader, they employ the Kaffir, and cultivate more sugar cane than the white man, they spend little or nothing in the Colony, and in no way, either from a social or economic point of view, or as a defensive force, take the place of the white men whom they have displaced. They are now claiming rights which they did not enjoy in India and are becoming a source of unrest and danger, not only in Natal, but also in the Transvaal. If the British Government, in view of their great interests in India, attempt to force these Asiatics on South Africa as British subjects, it will cause people to think it a heavy penalty to pay, for being a portion of the Empire.

Apart from their supplanting and driving away the white trader from the Transvaal, their influence on the native races is most detrimental. It is a question upon which much can be written, but there is no space in a book of this kind. Unless the Union Government tackles this question of Asiatic invasion boldly, and from a South African point of view, this will soon be no white man's country. 
When, owing to petty squabbles in the Cape Colony and the feebleness of the British Colonial Minister, Herbert Bismark - notwithstanding his statement that he wanted no inch of territory, but only to protect Luderitz and Hahn at Angra Pequana, - annexed the country, now German South West Africa, I urged Rhodes to get the Downing Street and Foreign Offices, to obtain the cession of this territory, in return for Heligoland-which Germany then wanted-but it was no use. That important island at the mouth of the Elbe was ceded, the equivalent being a promise not to interfere with British occupation of Zanzibar and Pemba (where Germany had really no right to interfere). As long as we are on friendly terms with Germany their occupancy of the South-West does not matter, but in case of war it would be serious and at all times gives them an excuse for being constantly in South African ports, possibly influencing the South African political situation.

Before the Majuba fiasco of 1880 , Delagoa was of no importance. It had no hinterland, no trade, no harbour or landing facilities. Since 1880 it has grown in importance, and was the port of entry for the Transvaal, and the depôt for the vast amount of all material accumulated by President Kruger, whilst preparing for the war with Great Britain 1899-1902. Since the Boer war British capital has made Lourenço Marques an important sea-port, and Portugal now claims a lion's share of the profits on seaborne goods and rail transport to the Transvaal.

In $1875 \mathrm{Mr}$. Hugo Nellmapius wanted a concession to run a camel transport from Delagoa to Pretoria, undertaking to carry ammunition, etc., for the Government, on certain conditions. Now trains run daily to Pretoria, via Witbank, direct to Johan- 
nesburg, and my dream of the railway line from Cape Town to Delagoa has long been fulfilled.

When Sir Theophilus Shepstone annexed the Transvaal, Joseph Henderson, Chairman of the Natal Bank, opposed the idea of carrying on the Delagoa line as it would compete with Natal, so it was stopped, but subsequently President Kruger restarted it.

The treatment of Macmurdo by the Portuguese authorities in Delagoa Bay and the disgraceful "Geneva award" after years of delay and when most of the original arbitrators were dead were common knowledge, but the railway is running now for the benefit of the Portuguese port and prior to the war for that of the Netherlands "Spoorweg Maatschappij" in Holland. It must be borne in mind that the English residents in the Transvaal and other parts of South Africa had no hatred of the Boer, but feared Paul Kruger and the influence exercised by such men as Leyds, and other Hollanders, over him, and this fear was shared by many Dutch Afrikanders.

In 1883 Doctor Jorrissen who had been largely instrumental in bringing about the war of 1880 and obtaining the retrocession - had gone with $\mathrm{Mr}$. Kruger to Europe, to get the terms of the Convention made more favourable to the South African Republic - was in bad odour with the Volksraad, and they decided to dismiss him. (I went to hear the debate.) Later, I had a long talk with Doctor Jorrissen. He was bitter at the treatment he had received from the Boers and told me that he often had grave doubts as to whether he had done right in assisting them to gain an independence, which they did not know how to make a proper use of, and that he 
had no hope for improvement, and anticipated bitter rivalry and party troubles and more to this effect. The only people who were well off in those days were the native commissioners and tax collectors. Mr. Kruger pauperised the lower class Boers by giving them doles out of the Amortization Fund, erven in the towns and plots of land about the country, such as Mapochs' Land and the Spelonken etc., Many of these people had inherited farms, or portions of farms and sold them, and were actually working for the Kaffirs. On my farms I had forbidden my natives to employ poor Boers, as I considered it demoralizing for buth. Now many Boers give their farms to natives to cultivate on half shares and do no work themselves. Natives are purchasing farms all over the country, while the poorer Boers congregate on the outskirts of the town, leading a miserable, demoralizing existence. The better class Boers will not employ them on the farms, saying that they are too exacting, and too lazy to work. When the Germans annexed South West Africa and there was trouble on the border of the Transvaal, Wessel Schutte told me in 1884 that if Germany attempted to interfere in South Africa, the Boers would stand by the British, nothwithstanding all that had happened.

In 1884 to 1885 the Boers on the Western border were on the war path; and Colonel Warren was sent to watch the position. No one knew what would happen, and the country was kept unsettled as usual, but I had my hands full night and day and could not bother about politics. In a paper issued at this time June 6th 1885 I find considerable excitement had been aroused in Pretoria by the effort of a strong party in the Volksraad to pass a resolution that the names of all persons who petitioned 
the British Government in favour of annexation, and later against the retrocession should be published, and that such persons should be disqualified from occupying seats in the Volksraad or office under Government, The debate was characterized by unrelenting bitterness and one member wanted the disqualification to be extended to the tenth generation! This was passed.

As I had taken no part in the annexation, this could not affect me personally. At this time Hugo Nellmapius with Sam Marks started the Hatherley distillery, and President Kruger was asked to christen it, which he did "De Volks Hoop!"-The people's hope, and the old conscientious puritan cut his hand badly with a champagne bottle, which instead of swinging, he jabbed against the chimney.

\section{On October 28th 1884, President Paul Kruger} sent for me to meet him in the Executive Council, and urged me to accept a requisition to re-enter the Volksraad. Again I refused on the ground that I had been unjustly treated at the time of Shepstone's annexation in 1877, when my straight-forward action in the Volksraad had been misconstrued by himself and others, especially the Hollanders, and also on account of my home having been looted by my own constituents, during my absence in Europe in 1880 . He begged me to forget and forgive, and now to help the country out of its difficulties. $\mathrm{He}$ warned me against Piet Joubert, who he said, was no real friend of mine, but I had learnt to distrust them all, and would not consent. At this time he was very jealous of Piet Joubert. He was annoyed and told people that he had begged Struben to come into the Raad and assist him, as, although, I often opposed him, he knew that I was honest, and told him to 
his face what I thought was right, but that as I had again refused to help him, he would have nothing more to do with me.

Another time I had a long talk with him about building a reservoir in the Crocodile River Poort in the Magaliesberg, to irrigate the rich loamy lands below, but he feared that there were too many riparian owners, and other difficulties, and nothing came of it. This dam would supply the Rand Mining area, besides irrigating miles of rich soil down the Crocodile valley. The catchment area above the poort is large and many permanent streams converge at this point. The river is subject to high floods, and one took away the bridge at Schoeman's, and carried away trees, grasslands, etc., and formed a dam in Vliegepoort, making a lake over thirty miles long. I remember Mr. Kruger asking me what I thought of the Transivaal, entering into a treaty with Germany. I answered that there was no room in South Africa for two European powers, that the British rule was established, and apart from that, the Boers would be less satisfied with German military rule, and official methods, than they had been with the milder and more liberal British administration. He said that I was always afraid of Hollander and German intrigue, and was prejudiced. I admitted my fear that any foreign interference in South African affairs would lead to friction and possibly bloodshed. I pointed out that Lord Carnarvon's proposed Federal Union scheme in $\mathbf{1 8 7 5}$ had not found favour, that it was safer to keep clear of European complications and that it was only self-interest that dictated the superficial friendly attitude of Holland and Germany, not any special love for the Afrikander Boers.

On July 3rd 1903, Paul Maré in Cape Town told me that General Hendrick Schoeman, openly 
declared that he was actually the cause of the war, because on behalf of Paul Kruger he had at the last election for President destroyed 500 of Piet Joubert's votes, on account of Joubert being against declaring war with Great Britain and being prepared to adopt measures to avert war, and to maintain the independence of the South African Republic. I have heard that Schoeman repeated this statement on other occasions. After the war he was killed by the explosion of a shell which he was showing to his children. This same H. Schoeman told me in Pretoria in 1899 (at the time that President Kruger had gone to meet Sir Alfred Milner in Bloemfontein), that he would soon see me in Cape Town, as the Cape Colony Boers would seize the railways at Hex River Pass, and that some of the Cape officials were on their side, etc. $\mathrm{He}$ was a commandant at Colesberg during the war, having invaded the Cape Colony ; but did not get beyond that point. $\mathrm{He}$ was a great friend of President Kruger's and quoted texts from the Bible on every possible occasion. I am of the opinion, that had Piet Joubert been elected President at the last ballot instead of Paul Kruger there would have been no war with Great Britain, and the Republics would have continued to exist, at any rate for some time, possibly for generations. Piet Joubert distrusted the Hollanders and Germans, considering them no true friends of the Afrikander people; merely exploiting them to further their own schemes-this was a sore subject between Kruger and Joubert.

Shortly before the outbreak of the war I was in Pretoria and walking up to Joubert's house with him he said to me, pointing to some German officers in uniform-" those are the fellows that are going to get us into trouble," and later in his house, while 
discussing the situation he said "if war comes, I am a Dutch Afrikander and Commandant General, and I shall do my best for my land and people; but if anything happens to me, you can always say that this war is none of my seeking; it will be a success for us at first, but will end in the loss of our independence. I hoped to avert it, but I am over-ruled. I must obey." He died during the war. 


\section{CHAPTER XXXII.}

\section{DISCOVERY OF THE WITWATERSRAND GOLD FIELDS.}

As I have already pointed out, after the Boer war of 1880-1881, the country was at a standstill, and many people practically ruined. I had tried in various ways to recover, but not being able to make headway, was almost in desperate straits, but determined that something must be done. For many years I had been convinced that the Transvaal was very rich in minerals, and I had already found indications of gold, silver, and other metals in various parts. As a boy, in 1853, I had accompanied Mr. Evans through the Drakensberg ranges in Natal, when he pointed out the occurrence of marine shells at considerable altitudes, giving evidence of the land having risen, and the ocean having receded. This gave me the idea, in 1885 , that the conglomerate beds of the Witwatersrand were (in remote geological periods) the southern sea-shore of Africa. That theory has not been disproved as far as I know. When, in 1858, I accompanied Mr. Evans to Zoutpansberg, he pointed out that the ranges north of Makapan's poort were a gold-bearing formation. In 1859 I found gold-bearing quartz in Doel Kraal, near what was afterwards the Esterling mine; but it was of poor quality, and nothing came of it, until years afterwards.

In $1860 \mathrm{I}$ sent some exceedingly rich specimens of hematite ore to Glasgow, but I was not able to

Note.-Some of this chapter is taken from an article sent in 1906 to the "Rand Daily Mail," and from other notes by my father.-(Editor.) 
exploit it. Even as early as in 1866, while driving from Pretoria to Potchefstroom, I noticed vertical talcose slates on the north-west end of the Witwatersrand, but at the time was unable to mine them. In 1860 and again in 1867, I found copper near Pretoria, and in the Zoutpansberg district; but the country was not ripe for mining base metals, and there was no one to follow up my discoveries. In 1868 I located titanic iron lodes, north of Pretoria.

As elsewhere more fully explained, in the early days (1870) I worked at the diamond fields-In 1872 I found and worked gold at Lydenberg. In 1876 Sir Theophilus Shepstone sent an Australian expert (a Mr. Armfield) to me for information, as to likely parts of the country to prospect for gold. I told him that the Witwatersrand was a good formation, and that colour of gold had been found in the creeks issuing from the range. He went there, but confined his prospecting to white-quartz reefs, so missed the conglomerates, and was not successful in locating a gold-reef. No further attempt was made at the time to do this. All this led up to my very strong belief in the possibility of finding gold in payable quantities in the country. In $1883 \mathrm{my}$ brother Fred who was in Natal, returned to "The Willows." $\mathrm{He}$ had had experience of gold-mining on Pilgrim's Rest, and Lisbon-Berlin mines, and we arranged a prospecting trip to Rooiberg, where he discovered gold and ancient copper workings, but he did not work these owing to lack of funds. In 1884 I purchased Jacoby's farm, Sterkfontein, and Geldenhuis' farm, Wilge Spruit. Fred went to inspect them and reported gold on them, and on Honingnestkrantz. We worked a shaft on Sterkfontein, sent some ore to Johnson, Matthey \& Co., (in England) for analysis, and it gave favourable 
results. Fred also prospected the range from Sterkfontein to Wilge Spruit and located the rich outcrop at the latter place, which we called the "Confidence Reef". He then discovered the conglomerates on Paarde Kraal, this we followed along the rand from Vogelstruisfontein and Driefontein, east of Knights, which is now the Witwatersrand Gold Fields. On March 4th I let George Moodie, George Hudson and Fred each take a share in the "Sterkfontein Junction Mining Co.," of which I was elected chairman and Fred manager. On the 7th he wrote that he was down 28 feet finding "colour" all the way in the shaft, and had traced the reef to Wilge Spruit. I engaged a Cornish miner named Arnold, and started him working on Wilge Spruit under Fred's supervision. The man was afterwards quoted as a discoverer, whereas he was merely a labourer in my employ. As he drank, and was too talkative, I took him to a copper lode on "The Willows" to get him out of the way.

On April 16th, 1884, I commenced to drive an adit into the hill to cut the reef. This took about two years (being in quartz-porphyry). At the back of the dyke we struck a strong stream of permanent water, which I had conducted down to Cliffendale farm, where we were then living.

During 1884 we were very busy. I purchased or leased properties along the line of conglomerate reefs, known as "Almond Rock" from its appearance, and called "Banket" by the Dutch. Fred was prospecting and looking after the mining work. Many friends tried to dissuade us from working them and told me that I would never see the money again, as gold had never before been found in conglomerate. On or about June 1st, 1885, Dr. Jorrissen came to me from Pretoria, and said that the 
executive had heard that I had discovered rich gold reefs in the Witwatersrand, and wished me to inform them if this were the case; as the Volksraad were discussing the necessity of issuing money in the form of Treasury bonds, and that they would be the laughing-stock of Europe, as they had just got the Transvaal given back to them by Mr. Gladstone ; but had not a penny in the exchequer. I admitted that I had found gold; but that I had not had time to develop the reefs, and that it would greatly interfere with my plans to make our finds public just then; but after much persuasion, I promised to think it over. He said there was no time to be lost or the Raad would pass the resolution, and the country would be bankrupt and discredited. I stated at that time - to the President and members of the executive, and the entire Volksraad assembled in Pretoria to meet me-that this was the most extensive and continuous gold field yet discovered. We thought at that time (judging by the formation) that there was a certainity of the conglomerate beds going down at least 500 feet-we now know that 2,000 feet has not probed their depth. I insert a report from a Pretoria paper which is as follows :-

"On the morning of the 5th June 1885, in the presence of His Hon. the President, the Chairman, and the members of the Volksraad, and a number of the townspeople of Pretoria, Mr. H. W. Struben of "The Willows," exhibited gold quartz of great richness, taken from a lode traversing the Witwatersrand, in the Pretoria district. The gold, (which was visible to the naked eye) permeated the quartz, and the result of some trials, made by some persons in the presence of the audience, was extraordinary. A button of gold and silver, smelted out of quartz by Mr. W. E. Dawson (who had also made some of the 
assays) was also shown-and the exhibition made a favourable impression on all present, especially on those who were best acquainted with gold-mining. In a speech made upon the mining question, Mr. Struben laid stress upon the duty of the Government, to foster and protect the mining interests; and of the Volksraad, by wise legislation not to crush but to assist in developing this new and important industry in the district. Mr. Struben said that complaints were heard from all classes of the poverty of the land, the loss of trade, and the scarcity of money ; but he maintained that such a state of things need not exist. The Transvaal, with its streams of water, grazing, agricultural, and especially mining capabilities, was the richest portion of South Africa and the district of Pretoria was, in his opinion, the richest part of the Transvaal. He considered that it would rest with the Government, the Raad and the people, as to whether these resources were developed, or smothered; it would not be the fault of the soil. He trusted that the Volksraad would so legislate this session, upon the important question of the revision of the gold law, that proprietary rights should be fully defined, acknowledged and protected, and no excessive duties and royalties levied that would cripple the mining industry. The digger, who was the exploiter of the minerals, and the consumer of the agricultural produce of the country, should be encouraged and protected; as long as he proved himself a law-abiding citizen; and that the Government lands should be thrown open to him. Mr. Struben further described the work done by his brother Mr. F. Struben in prospecting, mining etc., on the Witwatersrand, during the last sixteen months. A great deal of hard work had been done in tracing the reef for over twelve miles; sinking 
shafts etc.,- - some to a depth of 50 feet. Tunnels had been cut, and the reefs showed a larger body at a depth ; and as much as $121 / 2$ feet through, and the angle of dip 60 to 80 degrees.

The reef showed the following results by assay.

Johnson, Matthey \& Co., London.

Dec. 12th 1884

Assay of gold only

",

Ozs. dwts. grs.

$\begin{array}{rrr}1 & 7 & 12 \\ & 1 & 6 \\ & 2 & 15 \\ & 5 & 0\end{array}$

W. E. Dawson, Government Analyst.

$\begin{array}{ccrrrr}\text { May 7th } & \text { Gold only } & \ldots & 1 & 15 & 22 \\ 1885 & \# & \ldots & & 13 & 8 \\ & \# & \ldots & & 14 & 8 \\ \text { June 4th } & \text { * Pure Gold } & & 913 & 0 & 0 \\ 1885 & \text { Silver } & 362 & 12 & 10 \\ & \text { Pure Gold } & 301 & 3 & 17 \\ & & \text { Silver } & 123 & 19 & 9\end{array}$

Per ton of quartz of 2,000 lbs.

Mr. Struben further stated that he intended working as many properties in his possession as he could manage, at his own cost, that his machinery was ordered, and would be out shortly from England. He recommended those who could possibly manage it, to open up their properties, either individually, or else to get up small workable companies of moderate

- Note.-This incredibly rich result of $913 \mathrm{oz}$. to the ton assayed and re-assayed by the Government analyst, astonished everyone-and there was great excitement when it was made public. This was the highest analysis of any gold that had been found. The gold permeated the quartz, and was visible all through. This quartz was from the Confidence reef, not on the conglomerate reef of the Witwatersrand, and was never found so rich again. This extraordinary find on the Confidence reef was considered and called (in mining parlance) a " chimney." After this first discovery all trace of it was lost, and futher prospecting has up to the present failed to locate its continuation. 
capital, to exploit their lands, so as to keep the money as much as possible in the country, and not to rush off with everything to speculators, who would form gigantic unworkable companies on foreign capital; which it had now been proved (as in Lydenberg), did not pay dividends, and brought the country into discredit. His Honour the President responded, thanking Mr. Struben for the exhibition of the wealth of the country, and for his statements; and assured him that he could depend upon the protection and assistance of the Government to those who endeavoured to develop the mining wealth of the State.

The hon. chairman of the Volksraad, Mr. Hoffman, also said that it was, and would be, the wish and endeavour of the Volksraad to legislate in such a spirit, that industries of such importance should not, as Mr. Struben seemed to fear, be crushed to the ground; but that they would be assisted and protected, and the rights of proprietors of the land, as well as the diggers would be so assured that they would have reason to be satisfied."

A gold-crushing battery of five stamps, which I ordered from the Sandycroft foundry in England, was put up in a kloof on Cliffendale farm (Wilge Spruit), the first erected in that part of the country. On the 12th December, 1885, we started crushing the quartz in this battery; but from want of technical knowledge, and also in those days having no cyanide process (as it had not been discovered), we succeeded in catching only a very small percentage of the extremely rich but fine gold in the stone. I afterwards gave the "tailings"-which had run down the stream after passing over the mercury-covered plates of the battery - to a carpenter who was working for us, not realizing their value. He erected a brandy cask, driven by water charged with mercury, 
and extracted a couple of thousand pounds worth of gold which he took to England. He was a sly dog, and sat complacently smoking his pipe alongside the revolving barrel, pretending that he was getting only a little gold, while he really got more than we amateurs did off the plates in the mill. I only learned after he had gone how much he had made. The owners of the adjoining portion of Wilge Spruit formed a private syndicate, and, to encourage them I ordered and imported and had erected for them a five-stamp mill and turbine.

On February 22nd, 1886, I sent the first small consignment of gold to the Standard Bank of Pretoria consisting of 61 ozs. 11 dwts.

On June 17th, 1885, I had written a paper to the "Natal Mercury" giving a geological sketch of the Pretoria district, mentioning the intention of Fred to compile a geological map of the Transvaal, showing gold bearing areas, etc. I also wrote a long letter to Mr. Gardiner Williams-manager of the old Pilgrim's Rest gold field-advising him as to working there, after Fred and I had paid him a visit. I also asked him to come and see our work on Wilge Spruit before he went to America, and to alter his opinion about there being "no payable gold field in South Africa."

All this time, while Fred was working the mill, crushing quartz for testing values, for other companies; I was busy purchasing or leasing miningrights, and had a severe time, as some of the sellers -when offered higher prices by speculators-tried to repudiate their engagements, although I had paid them more than they ever expected; and we had by our energy and expenditure, made their properties (unproductive bare veld) of value, while they had 
done nothing but take the profits. The local and Natal newspapers published most eulogistic articles about the service I had rendered South Africa, but too lenghty to insert here. In those early days Fred and I were recognised as the discoverers of the Witwatersrand gold fields, having opened up and proved the reef for forty miles, from Vogelstruisfontein on the west, to Driefontein near Boksburg on the east. Since then many persons have posed as pioneers and discoverers after the event. A man named Walker had worked for me and seen our pannings of the conglomerates along the reef. $\mathrm{He}$ did get some rich specimens of the main reef on Langlaagte, but he cannot be considered the discoverer of it, as my brother Fred had found it before though nowhere so rich. Fred was undoubtedly the actual personal discoverer of the Witwatersrand gold-bearing conglomerates or " Banket."

I wrote numerous articles on the subject of mineral discoveries from 1853-1858, 1860-1866, 1869-1872, all ancient history now. On June 25th, 1885, Mr. Richard Smith of the Metallurgical Laboratory Royal School of Mines, London-sent an exhaustive report of analyses of a box of ores sent by me to him in November 1884. The figures would not be interesting in this narrative.

In $1886 \mathrm{I}$ purchased the then best known coal field at the source of the Wilge-river known as Steen-kool-spruit, the coal proved to be of excellent quality, but I did not work it. Now there are coal fields opened up all over the country, but competition has brought the price down, so that it hardly pays to mine coal, though this coal supply has made gold mining possible on a large scale. In an interview given in 1908 to "South Africa" by me is the following extract :- 
"I consider that the Transvaal has only been scratched, and that the mining industry of the Transvaal is only in its infancy-but the whole question of mining in the Transvaal hinges upon the words "labour, capital, and credit." Given labour at a reasonable price there is practically no limit to the possibilities of the country; but the Transvaal differs in this respect-as far as we know at present -from other countries, that, though the minerals discovered are generally in very large quantities, practically inexhaustible, yet at the same time there is no part of the country that has ever proved so rich locally, as for instance, Bendigo or Ballarat in Australia. The Transvaal is not so patchy, and not so rich; but nine-tenths of the mines in the Transvaal will pay, given strictly economical conditions. Very few will pay if you have to employ excessively expensive or unreliable labour. The tin industry of the Transvaal is in its infancy. This industry unfortunately has had a set-back owing to the nefarious dealing of certain unscrupulous people in "booming" it on paper, before legitimate work was done. I am convinced judging from what I have seen-and I have visited the tin mines, and I know the country rock of most parts of the Transvaal,- - that tin exists in large quantities in different parts of the country, widely separated, so that one is justified in assuming that there is a large supply of tin available. With regard to other base metals, I am aware that there is magnetic, hematite and chrome iron, and iron of every possible description in inexhaustible quantities. Whether that is of value so far in the interior remains to be seen. Whereas in America, you have got to cart your coal to your iron, or vice-versa, here you have very rich iron, coal, and lime, all within a short distance of each other. I am of the opinion that for some years to 
come we will not be able to compete against England, Germany, and America in the finely manufactured iron or steel article; but I do hold that the excessive sea-freight and land carriage should be sufficient protection, to allow of a profitable industry being started, for the manufacture of all articles of rough iron and steel work. You want your stamps, your fencing irons, your implements of all kinds, roofing irons, rails, pots, etc., and I see no reason why all these should not be produced in the country; because of the excessive carriage on these heavy articles imported from overseas." 



\section{AFTER W ORD.}

\section{By E. Struben.}

Though (as explained by my father) these Recollections were written chiefly at the request of his family, many men of note and position in South Africa and in England, also frequently urged him to do so, and to publish them; knowing that his unique experiences, as one of the first English pioneers in the country (especially in the Transvaal) would make it a most interesting record. His knowledge of the country, and of the different races in it, was profound and far-seeing. His opinion and experience were frequently sought by those in authority, and in the highest positions in the Government. His influence (as far as in him lay) was always used to further the highest interests of the country which he loved and adopted as his own.

$\mathrm{He}$ was a keen Imperialist, and a great believer in the future destiny of South Africa as an integral and useful part of the British Empire.

He realized the immense capabilities of the subcontinent as few did; its untold riches and inexhaustible resources-only awaiting development.

He deeply deplored the political squabbles and mistaken ideals of some of its people, which were retarding the country's advancement. He realized that these efforts differently directed, could make of South Africa-so highly favoured as to climate and conditions-one of the finest countries in the world. He chose to make it his permanent home, instead of spending what he made in it or from it elsewhere. 
His hopes and visions of its future welfare, and its high destiny among the nations must some day be justified, as he like all high-minded workers-faithfully striving for betterment and right-was a seer beyond his own immediate day.

I have kept this narrative in my father's own words and simple and direct style, merely re-arranging some of the events and incidents, in order to keep them in chronological sequence as much as possible. When (very rarely) finding it necessary to amplify or add anything, it was done from his own notes or writings. He had intended going over and re-modelling the whole of it himself, but was unable to do so, and as his health was not good, discontinued the writing of it in 1911, as there was so much he felt bound to look after in his affairs.

After seeing the Goldfields proclaimed and established, and thousands of people pouring into the country to try their fortunes, and when, through them money was coming into the Treasury, which before that was bankrupt, he worked on various bodies for the improvement of the country. He was on the first commission for framing the Gold Law, he was chosen as the first Chairman of the Chamber of Mines, and also served on the "Digger's Committee," on Boards of some of the leading mines, either as Chairman or Director. The life did not suit him, so after a time he sold out most of his mining interests, and left with his family for Cape Town, afterwards taking them to school in Europe, or to travel on the Continent.

He built the house at Rosebank, Cape Province, in 1890, which for the years since then has been a hospitable centre for the family, friends and many people in this country and from Europe. The Boer 
War of 1899-1902 caused him much sorrow and anxiety besides rather severe losses. He travelled with his wife and two daughters round the world in 1902 , leaving just before peace was declared ; hearing of Cecil Rhodes' death on their arrival in New Zealand. $\mathrm{He}$ strongly and frequently urged the establishment of a Mint to coin the gold and silver in this country instead of sending it all away; as it would save much expense, and would establish an industry giving many people employment but this scheme was not found possible at that time.

He was interested in all branches of agriculture, importing all kinds of farm machinery from England long before any one else in the Transvaal did so. He imported various kinds of cattle at different times, trying to improve the breeds in the country,Devon cattle, Hackney horses, Shorthorns and others. He had tried experiments in the earlier days on the Transvaal farms with Angora goats, ostriches, etc. In these matters (being a pioneer), he had to pay for want of experience sometimes, as always happens, but others have benefitted by his experience and many improvements which he endeavoured to inaugurate have been made.

$\mathrm{He}$ was much interested in schemes for the afforestation of suitable parts of the country, and was one of the first men who planted large Eucalyptus forests in the Transvaal (for mine timbers). He was also interested in schemes for irrigation and water conservation, making many dams and reservoirs on his own properties in various parts of the country.

After the family had settled at the Cape he was asked to stand for Parliament, but owing to rather indifferent health declined, preferring to take things more quietly, after the years of a strenuous and 
hard life-so he retired from public affairs; but continued to take an interest in various useful bodies and schemes for the general welfare. $\mathrm{He}$ was president of the Western Province Agricultural Society in 1904, and in conjunction with Mr. Rhodes, who had generously given the fine show-grounds at Rosebank to the Society, did a good deal in helping to improve that Society in its work for the country.

In the last years of his life he was much saddened by the political unrest, and the racial quarrels fomented by agitators and irreconcilables, often saying, that when he first knew the country, the language and racial questions hardly existed, they had become greatly accentuated by men posing as friends of the people. He hoped great things from the Union of 1910, and though many of these hopes are as yet unfulfilled, and the country has again been distracted by rebellion and the great war-those very events have brought out the loyalty of the more enlightened to the British Empire and who recognise the justice and freedom possible under that rule. In his own words " men of all nationalities and all parties hoped, that, with the Union, at last all sections of the community would recognise the wisdom of conciliation, and of building up a white nation of South Africans, whether their mothertongue were English, Dutch or other European language."

Though his last days were deeply saddened by the world war (which undoubtedly hastened his end, as that of many of the older generation) and he longed for peace for this distracted country; he realized that after the war, when life generally must be re-adjusted to new conditions a brighter future must dawn, bringing expansion, a wider outlook, and a greater development of the limitless 
resources of the country in which he always believed, in spite of many trials and difficulties. He died on October 18th, 1915, in his home at Rosebank. His noble upright life of strenuous endeavour was an example and an incentive to many, and a grand heritage to his children, for whom he did so much.

Articles in the local papers of October 19th, 1915, said of him. "His name was familiar to all, not only as a distinguished South African pioneer ever since his arrival in South Africa as a mere boy in 1850 , but also as the discoverer of the enormous mineral wealth of the Rand. Since 1890, Mr. Struben lived at Rondebosch; and though frequently pressed to stand for Parliament, his indifferent health led him to decline. His interest in public affairs, however, has frequently found expression in the vigorous and at the same time singularly moderate letters on the political situation, which have appeared in the "Cape Times" over the pen name of "Candidus Africanus." A man of wide interests, broad views, and an extraordinary knowledge of South Africa, its problems, and its history, he would have been a valuable asset in the political world. His death at the ripe age of seventy-five, removes a forceful personality, which has left its mark upon the development of South Africa in many notable directions. Mr. Struben's death means the loss, not only of a fine example of honourable and successful endeavour, but of a great store of ripe experience and practical wisdom, which, particularly in these days of rampant indiscipline, was in a very real sense, an asset to society and to the State.

It is a story not only of native shrewdness and quickness in catching the timely tide, but of grit, pluck and perseverance-and withal of sterling honesty and proved worth-Mr. Struben was as 
much at home with South Africans of Dutch extraction as he was with their British fellow-citizens; and by one and all with whom he came in contact, he was as much respected for his probity, as he was admired for his clear understanding and his sound judgment. Nobody loved South Africa with a deeper or truer love, and nobody felt more keenly the disappointing relapse to internal strife and dissension than he. All classes of the community in all the Provinces of the Union-for Mr. Struben was well known in all-will mourn his death." 



\section{DAY USE \\ RETURN TO DESK FROM WHICH BORROWED \\ LOAN DEPT.}

This book is due on the last date stamped below, or on the date to which renewed.

Renewed books are subject to immediate recall.

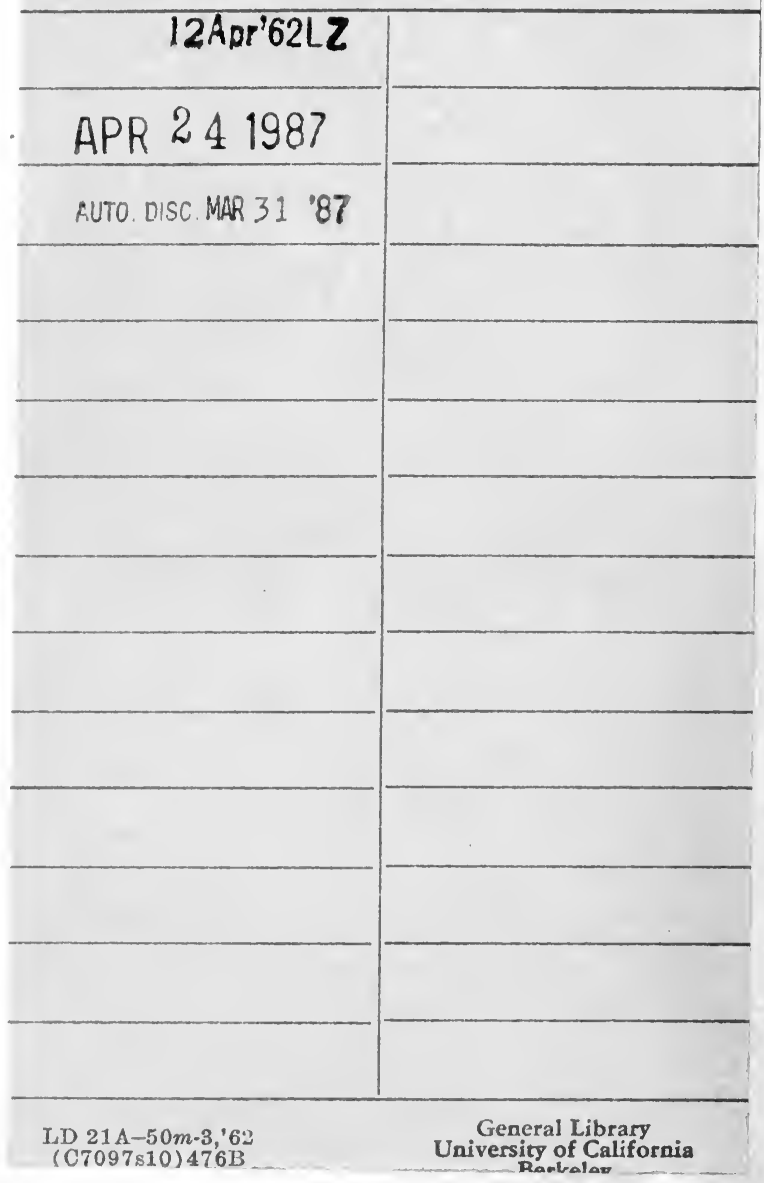




\section{$\bar{M} 310588$}

GENERAL LIBRARY - U.C. BERKELEY

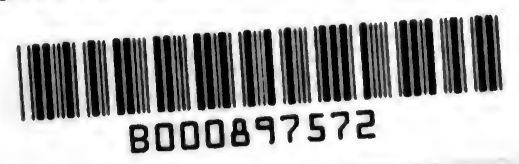


